

\section{THE PENNSYLVANIA STATE UNIVERSITY LIBRARIES}
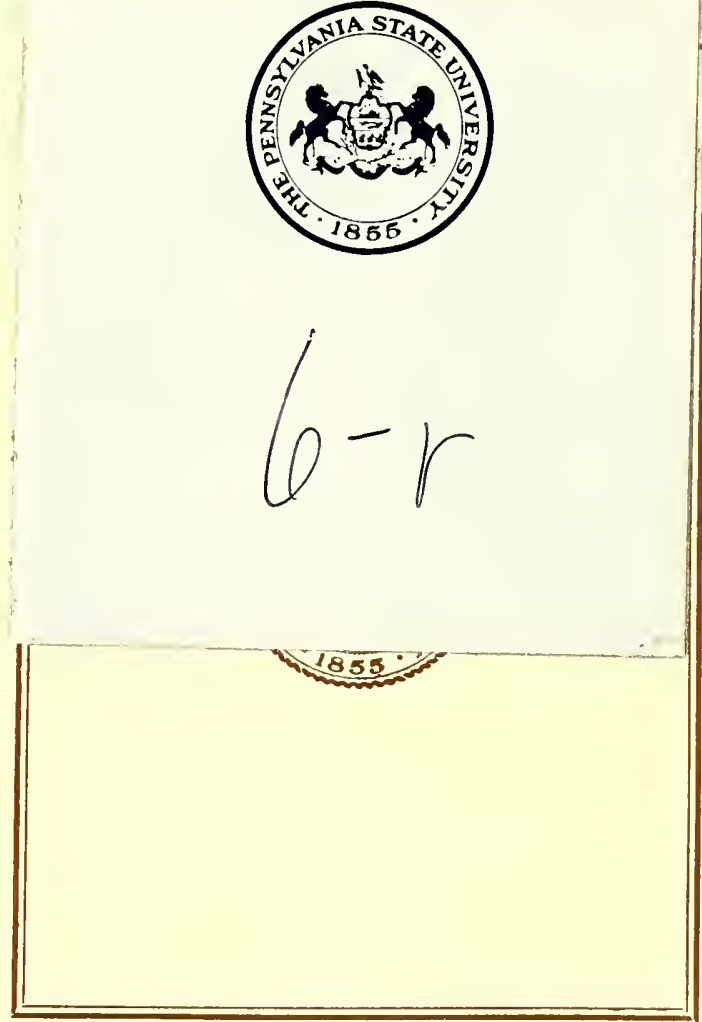




\section{TH E R E D C O W}





\section{THE \\ RED \\ COW \\ A N D I R FRIENDS}

BY PETER M ARTHUR AUTHOR OF "IN PASTURES GREEN," "THE PRODIGAL AND OTHER POEMs," "TO BE TAKEN WITH BALT," ETC.

TORONTO: J. M. DENT \& SONS, LTD. NEW YORK: JOH I LANE COMPANY $\therefore \quad \therefore \quad$ M C MXIX $\therefore \quad \therefore$ 


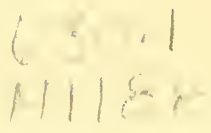

\author{
COPYRIGHT, 1919 , \\ By JOHN LANE COMPANY
}

Press of

J. J. Little \& Ives Company

New York, U. S. A. 


\section{THIS BOOK}

IS DEDICATED

TO ALL CITY MEN

WHO FEEL SURE THAT THEY

COULD FARM AT A PROFIT.

IF EACH ONE BUYS A COPY I CAN

AFFORD TO KEEP ON FARMING 



\section{$P R E F A C E$}

It is always a pleasure to avoid responsibility and it gives me a feeling of relief to be able to announce that I am not wholly responsible for this collection of sketches. When it was suggested that I should put together the articles dealing with the Red Cow, and the other farm animals, I felt reluctant to trouble the public with a somewhat frivolous book at the present time. It seemed as if Fate were with me for when it was decided to go on with the book it was found that my file of clippings had been lost. But the matter was still urged and, remembering that at different times readers had written to me saying that they were in the habit of clipping the articles for future reference, I published a paragraph telling of my predicament. The result was that I received clippings from all parts of Canada and some were even sent from neighbouring States.

Through the kindness of my unknown friends I am able to offer a book which they have really edited. Some of the sketches used would have been rejected had I relied on my own judgment, but finding that they had pleased some readers I decided 


\section{PREFACE}

that they might please others. Having the chance to shift the responsibility for the book from my own shoulders, I accepted it joyously. The unknown friends who did me the honour of preserving these articles as they appeared are the real editors.

I can further plead in extenuation that the clippings I have used were all sent to me by people who are familiar with the domestic animals and their habits. This should protect me from any charge of farm-faking.

Ekfrid, Ontario, January, 1919. 


\section{CONTENTS}

COWS

I. A Sick Cow . . . . . . . . . . . 15

II. Cow Troubles . . . . . . . . . . . . 22

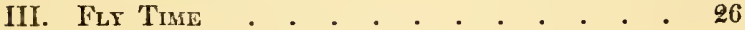

IV. The Red Cow's Calves . . . . . . . . 29

V. Insurgent Cows . . . . . . . . . 31

VI. Cow Troubles . . . . . . . . . 36

VII. The Bran Habit . . . . . . . . . 49

VIII. The Farrow Cow and Others . . . . 43

IX. Cow Enjotment . • • • • . • • . 50

X. Cow Kaiserism • • . . . . . . . 52

XI. A Nigut Session . . . . . . . . . 55

XII. A Calf Puzzle . . . . . . . . . 58

XIII. Cow Character . . . . . . . . 61

XIV. Calf Feeding . . . . . . . . . 63

XV. A Cow Trick . . . . . . . . . 66

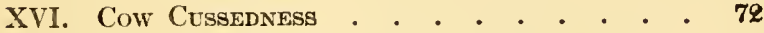

XVil. Teaching a Calf . • • • . . . . 75

XViII. Calf Exuberance . . . . . • • 77

\section{SHEEP}

XIX. Our First Sheep . . . . . . . . 83

XX. The First Lamb • . . • . • • • . 90

XXI. Sheep SUrgery • . . . . . . . . 93 


\section{CONTENTS}

XXil. The Patient . . . . . . . . . . 98

XXIII. Singaring . . . . . . . . . . 100

XXIV. VaIN Regrets . . . . . . . . . . 104

XXV. Sheep Sculpture . . . . . . . . 106

XXVI. Our Lawn Mower . . . . . . . 113

\section{PIGS}

XXVII. Clementine . • . . . . . . . . 117

XXViII. Feeding Pigs . . . . . . . . . 121

XXIX. Beatrice . . . . . . . . . . 124

XXX. Pig Frightfulness . . . . . . . . 128

XXXI. A PIg Bath . . . . . . . . . . 130

XXXII. In Extendation . . . . . . . . . 132

XXXIII. Beatrice Announces . . . . . . . 134

XXXIV. ReceIVING . . . . . . . . . . 137

XXXV. Feeding Time . . . . . . . . . . 140

XXXVI. Beatrice Belligerent . . . . . . . 144

\section{HORSES}

XXXVII. Dolly's DAY OFF . . . . . . . 147

XXXVIII. The Colt . . . . . . . . . 154

XXXIX. Honse Contrariness . . . . . . . 156

XL. A Great Scheme . . . . . . . . 158

\section{TURKEYS}

XLI. The Gobbler . . . . . . . . . . 163

XliI. His Prussianism . . . . . . . . 167

Xlifi. His Desertion . . . . . . . . . . 169

XliV. His Belligerency . . . . . . . . 171 


\section{CONTENTS}

XlV. His Cares . . . . . . . . . . 173

XlVI. His Troubles . . . . . . . . . 175

\section{DOGS}

XLVII. A Moral Tale . . . . . . . . . . 179

XLVIII. Sheppy's First Coon Hunt . . . . . . 181

XliX. A Rabbit Chase . . . . . . . . . 189

L. Frghts and Feuds . . . . . . . . . 192

\section{CATS}

LI. A Page of High History . . . . . . 197

LII. A Spring Orgy . . . . . . . . . . 200

BIRDS

LIII. A Disgusted Blackbird . . . . . . . 205

LIV. A Visitor . . . . . . . . . . . . 209

LV. A FAREWell . . . . . . . . . . 211

\section{GENERAL}

LVI. The Whole Bunch . . . . . . . . 215

LViI. Human Nature in Dumb Creatures . . . 221

LVIII. Early Observations . . . . . . . . 227

LIX. Bantams . . . . . . . . . . 232

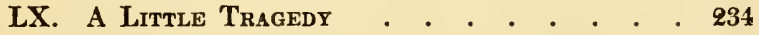

LXI. A ScIentific QUERT . . . . . . . 236

LXII. A Podltry Note . . . . . . . . 238

LXIII. Spring and the Livestock . . . . . . 210

LXIV. First Snow . . . . . . . . . 242

LXV. A "Skift" of SNow . . . . . . . . 244 


\section{CONTENTS}

PAGE

LXVI. A Spring Shower . . . . . . . . . 847

LXVII. DoIng Chores . . . . . . . . 249

LXVIII. Fishing . . . . . . . . . . . . 251

LXIX. A Lonesome Squirrel • • . . . . . 255

LXX. Fall Poultry Troubles . . . . . . 258

LXXI. Thankggiving Day . . . . . . . . 263

LXXII. September Notes . . . . . . . . 270

LXXIII. "The Dhmon RABbit” . . . . . . . 273

LXXiv. The Fate of "The Demon Rabit" . . . 278

LXXV. My Friends, the Trees . . . . . . . 288 
ב-1

COWS

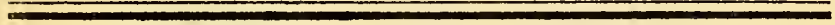




\section{A BALLADE OF COWS}

Fenceviewer I. a cow of parts, Aggressive, competent and bold, At every milking gives twelve quarts And doesn't give a-hoot!-(don't scold!) My Kerry cow, as good as gold; Fenceviewer II.-(boss, they say)

La Veau, turned three; Beans, two-year-oldThese are the cows I milk each day!

When Phœebus shoots his morning darts,

Or wet or dry, or hot or cold,

One to the dewy pasture starts

With clanging pails and pants up-rolled.

Again when evening doth enfold

The earth and sky in twilight grey,

Him at that chore you may behold-

These are the cows I milk each day!

Although unskilled in dairy arts

I've soaked some lore by experts doled, With gentle words that win their hearts

My cows from kicking I've cajoled; And of all cattle, horned or polled,

Pure-bred or grade, own them who may, Mine suit me best. They'll not be soldThese are the cows I milk each day!

\section{ENVOX}

Prince, if you ever in the wold

At milking time should chance to stray,

I'll let you drink all you can hold-

These are the cows I milk each day! 


\section{I.-A Sick Cow}

7 HIS week the monotony of the winter has been broken. I have been sitting up with a sick cow. Fenceviewer I. has suffered the first check in her career of rapacity, voracity and capacity. A couple of days ago it was noticed that she was off her feed-that she only nibbled at the blue grass when it was put in her manger. Knowing that in her normal condition she is an incarnate appetite- "A belly that walks on four legs"-I knew that something was the matter. I could not imagine her refusing to eat until Death had "clawed her in his clutch," so I took the matter seriously from the beginning. I also noticed that she did not take kindly to water, but stood over it and shivered. There was no doubt about it. She was a sick cow. After a hasty consultation it was decided to give her a dose of salts, and I commandeered all that we had in the house-almost a pound. After it had been dissolved in about a quart of warm water I took some further advice and added to it, 


\section{THE RED COW}

for her stomach's sake, a couple of tablespoonfuls of a sovereign liniment and embrocation, good for man and beast, and paramount for poultry, a remedy for all ills that any kind of flesh is heir to, may be used internally or externally at any time of the day or night without regard to the phases of the moon or the signs in the almanac. All I know about this remedy is that it is a red fluid made of red pepper, red whiskey and all the other red-hot things in the Pharmacopœia. It is the stuff that was once given to an ailing coloured woman, and when she was offered a second dose she declared with vigour, "No thankee! Ah've done made up ma mind never again to take nuttin' that wattah won't squench." Having added this mixture to the salts $I$ put it in a quart bottle, called for help, and proceeded to put the red dose into the red cow.

****

We did the trick in the most approved fashion. I caught her by one horn, slipped my thumb and finger into her nose, and elevated her head so that the other man could pour the mixture down her throat. After the last drop had gurgled down I turned her loose and stepped back to watch results. She shook her head, rattled her chain, lashed her 


\section{A SICK COW}

tail, wriggled her backbone, coughed and sneezed and showed other unmistakable signs of wrath and discomfort. She did not seem to appreciate our efforts in her behalf, and after I had thought it over for a minute I realised what she was objecting to. I put myself in her place. What would I want to do if any one had forced a dose like that down my throat? I would want to spit, of course. That was what was the matter with old Fenceviewer. She wanted to spit, but the limitations of a cow are such that she couldn't do it. If she were only able to do it she would spit like a cat. I felt truly sorry for her, but as I had done everything for the best I didn't do any worrying. While watching her I noticed that she grunted faintly every time she breathed, so I decided that we needed some expert advice and called in a neighbour who has had much experience with cows. After he had pressed his ear to her side for a while he diagnosed her case as pleuro-pneumonia. It had never occurred to me before that dumb animals could have diseases with Latin names and that probably needed high-priced treatment. He advised calling in the farrier at once, and I dispatched a boy to the nearest telephone to do this, and we went to the house to await his arrival. The 


\section{THE RED COW}

boy reported that the farrier was out, but that he would come as soon as he could. While waiting we talked about all the sick cows we had ever known, and as most of them had died I found the conversation somewhat depressing. I can honestly say of Fenceviewer I., "With all thy faults I love thee still." She is the progenitor of the whole flock, and her strain is the kind I need. She can rustle for herself except when she is chained up, and if she had to do it she could get through the winter by licking the moss off the trees. She is no stall-fed exotic, but a hardy annual who in spite of her good breeding has a touch of the qualities that made the pioneer cows endure hardships and give rich milk. I could ill afford to lose her from either a financial or scientific point of view. We whiled away several hours with gloomy forebodings, occasionally taking the lantern to go to the stable and look her over. But there was nothing we could do for her, and she grunted rhythmically every time she breathed, sometimes standing up and sometimes lying down. About twelve o'clock we decided that the farrier was not coming, and the neighbour went home and I. went to bed. Just as I got sound asleep the household was aroused by shrill whistling, and I got up to find that 


\section{A SICK COW}

the farrier had come. Getting into my clothes as quickly as possible I took the lantern and hurried to the stable. The farrier examined her, confirmed my neighbour's diagnosis and added that the attack was complicated by a serious case of "impaction of the rumen." I was glad that he didn't say that she had appendicitis or adenoids, for I had made up my mind that I was neither going to pay for a costly operation nor to send her south for her health.

* * * *

While the farrier was mixing another dose-he had approved of the one I had given-I enquired cautiously about her ailment. When the big words had been simplified for me I found that what she was suffering from chiefly was indigestion and pains in her tripe. This gave me much relief, for I felt that if there ever was a cow that deserved to have indigestion it was old Fenceviewer. Some of you may remember that a couple of years ago she gave me a scare by eating a bushel or so of corn. But she got away with that without any bad results, so I was puzzled as to what she could have eaten that had disagreed with her. I knew that she had not had too much of anything, for she is kept tied up most of the time. Then I remembered that when feeding 


\section{THE RED COW}

the bottom of the stack of cornstalks I had noticed that the butts of some of the sheaves were mouldy. As the tops of them were fresh and good I had fed them, thinking that the brutes would know enough not to eat the parts that were damaged, but it doesn't do to bank on the intelligence of even the brightest cows. The farrier agreed that that had probably started the trouble, and I felt somewhat disgusted with myself. When I didn't know enough not to feed such stuff I need not expect the cows to know enough not to eat it. It was a wonder that more of them were not ailing.

After the farrier had filled the quart bottle with a mixture that smelled suspiciously like doses I have had to take myself when my stomach has been out of order, we went through the exercise of holding up her head and pouring it down her throat. This time she tried so hard to spit that she almost did it and I wished that she had been able, for I know what nux vomica and such stuff tastes like. The farrier then mixed a bunch of powders to be given her in a bran mash, every night and morning, and judging from the way she goes at the bran she has forgiven him everything. I may say, by the way, that the bran is now about the most expensive part of the dose, and 


\section{A SICK COW}

if prices keep on as they are going we will soon have to get our bran for sick cows at the drug store instead of at the flour and feed emporiums. I am glad to be able to report that at the present writing Fenceviewer $I$. is taking her feed standing up, and chewing her cud between times, so I guess she is going to pull through all right.

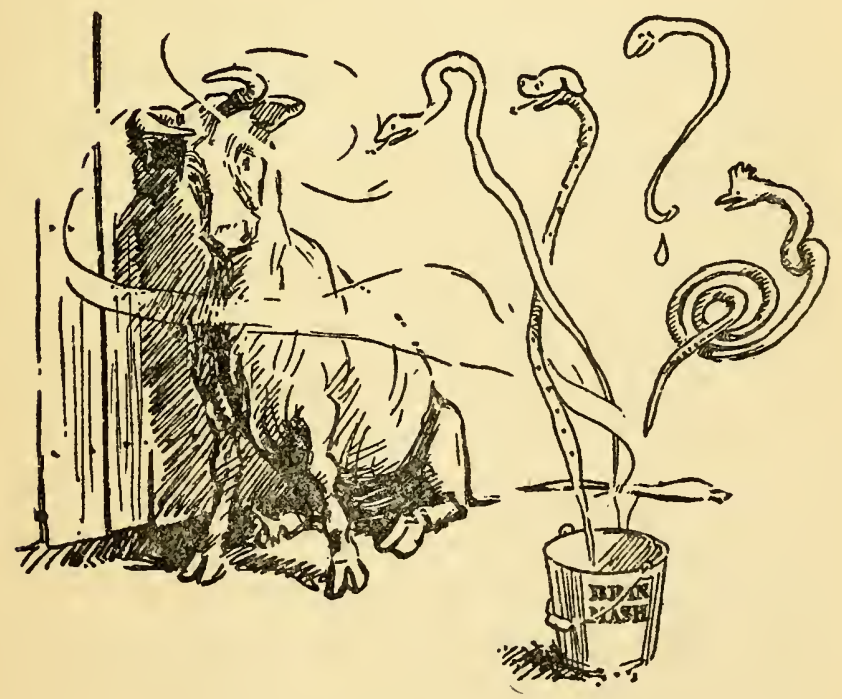




\section{II.-Cow Troubles}

T KNOW I should have a silo for the corn-stalks or at least a cutting box, but I haven't either, and the result is that $I$ have trouble. How to get ten-foot stalks into a four-foot manger is a problem that I have to wrestle with every day and I am no nearer the solution than I was at the beginning of the winter. I have to stand them on end in front of the cows and as the soft ears were all left on the stalks, the cattle go at them wildly and toss them all over the place in their hurry to get the ears. The result is that every few days $I$ have to clean out the rejected stalks from the mangers and the front of the stalls and that makes more trouble. I wish some one would tell me why it is that the tines of a fork will slip through corn-stalks so easily and are so hard to pull out. I do not find very much trouble in getting a good forkful of the stalks but when I carry them out to the hole in the barnyard where I am piling them in the hope that they will 


\section{COW TROUBLES}

rot some time I have a wrestle with them that starts me quoting poetry:

“On Astur's throat Horatius

Right firmly placed his heel;

And thrice and four times tugged amain,

Ere he wrenched out the steel."

When I have thrown down my load I find that every tine has three or four stalks on it so that it looks like Neptune's trident entangled with seaweeds. But though it is a nuisance clearing out the stalks in this way $I$ have a vivid recollection of trying to pitch manure that had corn-stalks mixed with it and I have made up my mind that that will never happen again. I try to keep them out of the manure as far as possible, even though I may be robbing the "stercoraceous heap" of some of its most valuable fertilising constituents.

$$
\text { * * * * }
$$

The more I work among cows and study their ways the more puzzling they become to me. Sometimes when I am feeling a bit conceited I think I understand them pretty well and then something happens that puts me entirely out of countenance. One warm day last week, when I had let them out to water, I thought I would let them stand out and 


\section{THE RED COW}

sun themselves for a while before driving them back. to their stalls. I half remembered that the gate to the young orchard had been opened when the snow was deep and left opened, but I did not give it a thought. The government drain had been flooded and was covered with slippery ice that I was sure they could not cross, and I felt that everything was serene for a pleasant sunbath for the cows. Half an hour later I took a look to see where they were and every last one of them was in the young orchard picking at some long grass that had been brought into sight by the thaw. There was no waiting about starting to get them out, for you know the way cows have of rubbing their necks against young trees and breaking off limbs. Luckily they had not started rubbing and had done no damage, but $I$ had to do some rushing around before I finally got them out of the orchard. But when I got them back to the icy government drain there was all kinds of trouble. You never saw such a timid bunch of cows in your life. It was absurd to think that they could walk on ice like that and what was more they wouldn't do it. But I knew that they couldn't fly and that they had crossed that ice on the way to the orchard and I was just as stubborn as they were. Gritting 


\section{COW TROUBLES}

my teeth with determination I went at those cows and in a few minutes each one of them had been personally conducted across the ice by an earnest man who was earnestly twisting her tail. I then made the discovery that twisting a cow's tail puts a lot of ginger in her for when the last one was across they began to romp around the field. I saw that I would have trouble getting them into the stable and went to the house to get some one to help. I don't think I was in the house five minutes, but when I went out again with reinforcements, those wretched cows were on the other side of the government drain again and headed towards the orchard gate. Apparently it was no trouble at all for them to cross ice when on the way to mischief. I may say that on the return trip they did not wait for much tail twisting. Possibly the second twist hurts more than the first. Anyway they hustled back and didn't stop to argue with me. 


\section{III.-Fly Time}

A

$\mathrm{S}$ a rule old Fenceviewer hasn't much faith in me. Of course, this is entirely due to her independent and predatory nature. She is accustomed to rustling for herself and apparently does not feel the need of cultivating a thankful spirit for anything I do for her. I even suspect that she would renig at milking time if it were not more comfortable to play the game and give down. Up to the present we have continued to live on the same farm without serious disagreement, and yet without any bond of affection being established. She goes her way as far as the fences will allow, and I go my way. But there are signs of a change. During the past week her actions have indicated that she thinks I may be of some use after all. This is because the flies are unusually bad this year. The cattle have been simply covered with them. When we took them into the stable at milking time they were in such misery and so restless that it was almost impossible to milk them. They were all 26 


\section{FLY TIME}

the time lashing their tails, swinging around their heads and trying to paw up hooffuls of dust and dirt against their sides. Though we have ingenious little contraptions for holding their tails it seemed positively cruel to use them when they were being pestered and bitten, so, after due consideration, we bought a spray pump and a gallon of some coal tar by-product that smelled like a political investigation. After milking we proceeded to spray the cows thoroughly with the vile smelling stuff, and if they had not been thoroughly chained the trick could not have been managed. But though the operation seemed unpleasant to every one concerned it was most unpleasant of all for the flies. Hundreds of them fell to the ground stupefied, and those that kept on the wing kept at a distance from the cattle. After the cattle had been sprayed a few times they objected less and less, and old Fenceviewer seemed to get it through her head that the spraying was being done for her comfort. Although some of the younger cattle still struggle she lowers her head and wiggles her ears and stands perfectly still. Apparently she understands that the spraying rids her of the flies, and the look in her eye when I come along with the spray pump is positively friendly. In fact, she doesn't 


\section{THE RED COW}

seem happy till she gets it and I suspect that if I missed it any morning she would bawl for it. But all nonsense aside, spraying the cattle to keep off the flies strikes me as being not only a humane but a profitable thing to do. They cannot be expected to do business as usual in the way of giving milk when they are tormented by hordes of flies. We are also spraying the calves at feeding time and they seem much more comfortable.

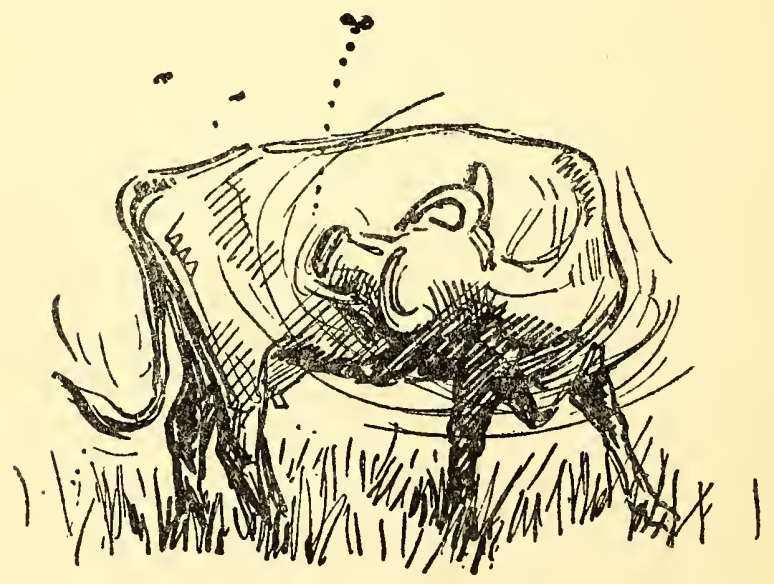




\section{IV.-The Red Corw's Calves}

TaLK about excitement! When I came home from the excitements of the city to enjoy the quiet life on the farm I ran into more excitement than I had met with on my travels. Although it was after dark when I got home nothing would do but I should go out to the stable to see the new calf. Although I wanted to have my supper first I was over-ruled and I followed the lantern, with the whole family at my side. I might have suspected that there was something unusual about Fenceviewer's new calf, but I put down the enthusiasm of the children to the fact that it was a brand new calf. The little comedy was properly staged. I was not allowed to see anything until I had reached the calf pen. The lantern was then swung in front and every one yelled at once. I got the situation at a glance, and I guess I yelled too. The red cow had given birth to twins! There they were, as nice a pair of red calves as any one would wish to see. I couldn't blame the little folks for being excited. According 


\section{THE RED COW}

to those who know, this is the first pair of twin calves that ever was born on the farm. But what interests me is this further development of the red cow strain. You may remember that when summing up their good qualities I recorded the fact that Fenceviewer and her progeny give me aid in farm work by testing the fences every spring so that I put them in good shape for the summer. Moreover, they almost invariably bear heifer calves, so that the flock increases rapidly. To these excellent qualities is now added the unexpected pair of twins. The strain is developing steadily, and some day Fenceviewer and her descendants will force the authorities to give them a corner in the herd book. 


\section{V.-Insurgent Cores}

HESE are the days when the cattle become discontented with their pasture and begin to go on a rampage. Fenceviewer $\mathbf{I}$. and her brood are running true to form and living up to their best traditions, but I have lived with them too long to be taken entirely unawares. As soon as the pasture withered with the long drought they began to take an undue interest in the cornfield. Although it is a comparative failure it still looks green and succulent compared with everything else on the farm, and the cattle have been stretching their necks over the fence and bawling. The first to get through and enjoy a feed were Fenceviewer's twins. Although they are small they are thrifty and seem to inherit much of their mother's resourcefulness. Already they are taking a lively interest in the fences. Although I felt quite safe on that point, it happened that during the haying a board was broken in a gate. The twins found it and worked their way through and 


\section{THE RED COW}

had their first feed of stolen corn. After they had been driven out and the gate had been mended I felt secure again, but it was a false security. A few days later I happened to notice a commotion among the cows and saw at once that Fenceviewer II. was beyond the fence and making straight for the corn. The Government drain was dry and she had managed to push through where the ice had loosened the wires that were used for a home-made flood-gate. But would she go out where she got in? Not if she knew it. She seemed to have an idea that if she fooled us about that hole she could get through some other time. She was evidently working alone when she found it for even her piratical mother had not noticed it, and had failed to follow, though she bawled with surprise to see her daughter so near the cornfield. After three or four attempts to make her go out through the ditch we finally had to give up and drive her out through the gate. Then we fixed the hole and now we are waiting for the next outbreak.

The cattle had not attracted our attention all summer except at milking time, but a few days ago the alarm was raised that Mars-the yearling steer -was in a well, and the whole family had to be as- 


\section{INSURGENT COWS}

sembled to get him out. The well is not really a well, but a drinking place that has been fixed so that the cattle can help themselves. There is a low place in the woods where there is a quicksand bottom about four feet from the surface and for many years it has furnished an unfailing supply of water. Many years ago a shallow well was scooped out from which the cattle can drink at all times simply by having a plank left off the top so that they can drink as from a trough. As there is a pond nearby which supplies them during the rest of the season they do not use the well except when other supplies fail. This year the other supplies failed completely and the drinking well was fixed for them with scantlings nailed across the opening a couple of feet apart. It was looked upon as quite safe, but apparently when a yearling steer ventures to go for a drink before his betters he is likely to be taught a lesson. Mars must have been down on his knees drinking when one of the big cows came along and poked him right through. When found he was not worrying a bit. He was standing in about two feet of cold spring water contentedly chewing his cud. He didn't seem to care whether he was rescued or not. As the day was unusually hot I could understand his feelings exactly. But for 


\section{THE RED COW}

the good of the water supply he had to be disturbed. We found that all we needed to do was to enlarge the opening, give lis tail a twist and let him do the rest. Then we cleaned out another well of the same kind so that the water came clear and cold from the quicksand and closed the first one so that nothing could get in. I know that a quicksand bottom is not considered a good thing on a farm, but there is only this spot of it, and in a dry season it seems like a dispensation of Providence.

$$
\text { * * * * }
$$

On the way home I had an experience that I had not enjoyed since returning to the farm. While we were busy cleaning out the well clouds began to gather, and even though a thunderstorn did not develop, rain began to fall. It was a sun shower of the kind that used to make children sing:

$$
\begin{aligned}
& \text { "Rain, rain sunshine! } \\
& \text { Sure to rain to-morrow!" }
\end{aligned}
$$

We had no time to make a dash for the house, so we took shelter under some spreading beech trees at the edge of the woods. There used to be a tradition that lightning never strikes a beech tree, but that was not our reason for choosing them. They had the thick- 


\section{INSURGEN'T COWS}

est branches and most plentiful leaves and offered a better umbrella. At the beginning of the shower tree-toads began to call, and many kinds of birds sounded notes that were unfamiliar. Everything seemed too happy to keep still. The cattle in the pasture stopped eating as if to stand and enjoy the cooling, shower bath. The sunlight filtered through the falling rain and altogether the scene was one that offered Nature at her best. But before long the rain began to drip through our roof and we had to do a lot of stepping about before we found a comfortably dry spot under the thick trunk of a leaning maple. As there was no lightning there was no objection to leaving the beech trees. Presently the shower passed and we walked home with everything greatly refreshed. But when I looked at the thermometer and found that it stood at ninety-six in the shade I almost wilted. If I had known it was so hot I wouldn't have dreamed of undertaking so strenuous a job as cleaning out a well. 


\section{VI.-Cow Troubles}

CAY, what do you do when a cow swallows a rubber ball? I don't mean one of the hollow

kind, but a solid rubber ball about the size of a small Ben Davis apple-one of the kind that used to sting our fingers when we played "Long Injun" with them at the old school. I hadn't seen one for years, but this spring an old one was ploughed up in one of the fields, and as it still retained its shape and would bounce the children used it to play with. Well, last night one of the boys went to bring up the cows, and when a cow strayed apart from the bunch and stood still he threw the ball at her. He missed her, but as the ball rolled past she ran after it and grabbed it, apparently under the impression that it was an apple or a potato, or something good to eat. I was in the stable when the boy came to tell me about it as a great joke, and I was inclined to think that the joke was on him, for I felt sure that as soon as the cow found that she 


\section{COW TROUBLES}

had been fooled she would drop the ball. But when I went out to the gate to let in the cows I found "Beans," granddaughter of old Fenceviewer, with her head and neck stretched out, doing her best to chew and swallow something that was stuck in her throat. She was half choked, for her eyes were popping out, and she was red in the face-or at least had the same expression that a human being has when red in the face. With my customary presence of mind I rushed to her side and began to slap her on the back the same as we do to the children when they choke on something or when something "goes down the wrong way." But it did no good, and the slapping made her bolt to her stall in the stable. I immediately began to feel her throat, and was not long in discovering a lump that seemed about the size of the missing rubber ball. I then followed my usual practice when in real trouble. I sent for a neighbour.

$$
* * *
$$

By the time my neighbour had arived the cow had stopped her frantic swallowing, and I had become suspicious that the lump I had been feeling in her throat was not a lodged rubber ball, but the end of her wind-pipe. My neighbour confirmed this suspi- 


\section{THE RED COW}

cion, but he could not suggest what I should do under the circumstances. That is the trouble with my cattle. They are all the time doing things that are outside of the common fund of experience. Other people's cattle seem to confine themselves to ailments that can be treated according to recipes given in the Veterinary Guide, or in the back numbers of "The Farmer's Advocate," but mine are all the time doing something unexpected. Still, I got a line on what was an entirely new wrinkle to me. A person of experience brought me a beetle ring and told me that the way to dislodge a substance from a cow's throat was to open her mouth and keep it open with the beetle ring. Then I could slip my hand through the ring and remove the obstruction with my fingers, or take a piece of rubber hose and poke it down her throat. That sounds to me like a very plausible method, but as the little cow had stopped gagging and had commenced chewing her cud, it was considered unnecessary to try the operation. And speaking of her cud -she should not be in any danger of "losing her cud" in the near future. That rubber ball should provide her with just about the most serviceable cud that a cow ever had. Whenever the pasture gets short she can bring up her reserve rubber cud and 


\section{COW TROUBLES}

keep herself contented with it until the pasture grows. Seeing that most of our young people seem to find it necessary to provide themselves with cuds of durable, rubbery gum on which they chew during most of their waking hours, isn't it just possible that our cows would be more contented and give more milk if we provided them with rubber cuds? If I could only get scientific endorsement for the scheme I would have no trouble in promoting a company to supply rubber cuds for cows. Anyway, "Beans" seems to have suffered no inconvenience from having swallowed that indurated knob of gutta percha. When I was driving her back to the field after milking she hastily picked up a nice clean corn-cob and put it down as dessert to the rubber ball-all of which leads me to believe that she inherits her grandmother's digestion as well as her appetite. I am willing to bet that a post mortem on Fenceviewer would reveal a collection of junk that would give impaction of the rumen to an ostrich. Still, if any authority on cows thinks that having a rubber ball in her midst may be injurious to "Beans," I wish he would write and tell me what I should do.

$$
* * * *
$$

And now having asked for help, there should be 


\section{THE RED COW}

no objection if $I$ offered a couple of suggestions that seem to me to be valuable. Of course, they may be quite well known, but there are sure to be a few backward farmers like myself who will be glad to be enlightened. The first deals with the value of the oldstyle wire fences when feeding calves. The most annoying thing about feeding calves in a pen is that when trying to teach a new calf to feed without the finger a man usually has to step inside. While he is wrestling with the beginner other calves will try to get into the pail or to get nourishment from his coattail, occasionally administering a bunt to express dissatisfaction with the taste of the cheap dyes they now use in cloth. If you have the right kind of wire fence around your calf pasture you can keep on your side of it and let the calf stick his head through. As his head is the part you really have to deal with you can gradually teach him to take his milk without inhaling too much, and at the same time you have less trouble in slapping interfering calves on the nose. The wire fence has robbed calf-feeding of half of its terrors for me. So much for that suggestion. The other has to do with greedy horses. One of our horses ustally tries to get all her oats in one mouthful, and, when she tries to chew them she scatters 


\section{COW TROUBLES}

them all over her manger and stall. On advice, we have put several corn cobs in her feeding box, and now when she is given her oats she has to take reasonably sized mouthfuls and there is no waste.

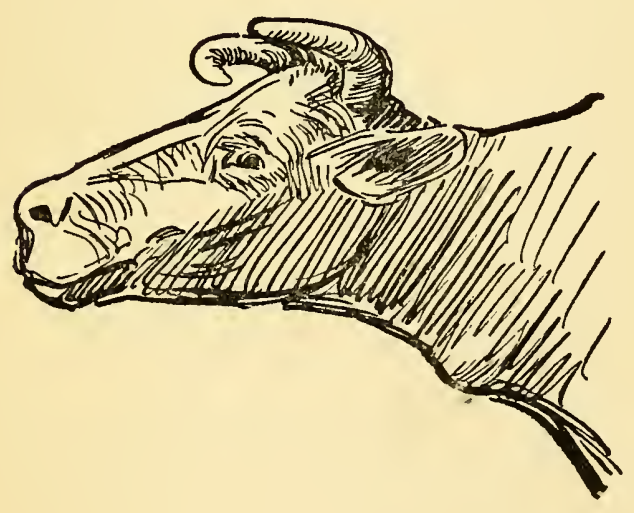




\section{VII.-The Bran Habit}

TAM once more in trouble. Fenceviewer the Third, direct descendant of Fenceviewer the First, has acquired the bran habit. For the past month $I$ have been giving her a bran mash every milking time but when I was away on a trip those in charge had cut off her supplies and as nearly as I can judge she is suffering from a sort of bran delirium tremens. She comes to the gate of the pasture field whenever she sees any one around and bawls and bawls. When we bring her in to milk she whines and bawls during the whole milking time, and judging from her tones her sufferings are really acute. With bran at its present price I feel that she must be cured of the bran habit, though I hardly know what to do in the case. She is so nervous and unhappy that I think something should be done, and if any reader knows how to cure a cow of the bran habit I shall be delighted to receive instructions. 


\section{VIII.-The Farrow Cow and Others}

T DON'T know that I ever sat down to write an article when feeling so full of improving 1 thoughts as I do at this blessed minute. A lot of things have happened lately, and all of them were of the kind that seem designed "To point a moral and adorn a tale." To begin with, the boy and I were working in the garden yesterday, when I happened to notice some dark object on the ground between two of the cows that were lying down in the pasture, up near the woods. I ventured the opinion that it was a newly arrived and not unexpected calf. The boy took a look and said it was a stone. I could not remember having seen a stone in that place, but I was busy and did not stop to argue the matter. After a while $I$ chanced to look up again and saw that all the cattle in the pasture had gathered around the dark object on the ground and were sniffing at it. Once more $I$ ventured the opinion that it was a calf. 


\section{THE RED COW}

"But that is not where the cows were when you were looking at them before."

"Why, yes it is."

"I am sure it isn't."

"Don't talk nonsense. Don't you think I can remember where the cows were when $I$ was looking at them? And that calf, or whatever it is, is lying exactly where it was when I spoke to you about it."

"But it was not there they were at all. And now I can see the stone that was between them as clear as can be."

My temper was rising but I looked and saw a stone about ten rods to the east of the object I was looking at. A couple of questions brought out the fact that we had not been looking at the same couple of cows, nor at the same object on the ground. That explained everything, and while we were settling the matter the dark object I had been looking at got up and began to stagger around on wobbly legs. It was certainly a calf. But you can see the lesson to be learned from the incident, can't you? Before you get into a red-hot argument with any one be sure that you are talking about the same thing. Thus endeth the first lesson. 


\section{THE FARROW COW AND OTHERS}

The calf belonged to the purposeful and strongminded red cow. Of course, she was very proud of her calf, and mooed solicitously when we approached to examine it. But strange to say she was not nearly so excited about it as her oldest daughter, a quiet and hitherto well-behaved cow that has been milking all winter and is farrow this season. Judging from her actions she had adopted the new calf, and had taken out adoption papers before we arrived on the scene. She ran around and bawled and acted silly as soon as $I$ began to push the calf towards the barn. By the way, pushing a young calf that braces its front legs and insists on lying down every couple of rods while its real mother and an idiotic farrow cow are threatening to run over you all the time, is a job that is rather trying on the temper. But $\mathbf{I}$ finally got it through the gate, and proceeded to push it along towards the drive shed where I could get it out of sight. The mother objected, of course, and bawled her protest as loudly and ineffectively as a loyal Opposition when a Government is putting through a railway subsidy. But the farrow cow made as much noise as a self-elccted reformer. She stood by the gate and pumped up basso-profundo bawls from her second or lower stomach. Every 


\section{THE RED COW}

time she bawled she humped her back and moved her tail up and down like the handle of an old-fashioned wooden pump. But I paid no attention to her. I could not see where her feelings were being lacerated, and I kept right on picking up the calf and setting him on his wobbly legs and pushing him towards the drive-shed. But just as I reached the door and the calf had gone down again I was startled by a yell behind me. I turned hastily, just in time to see the farrow cow in the act of shredding herself through a tight barbed wire fence. I was too late to head her off, and, as I watched her struggles, I felt that when she got through she would be of no use for anything but Hamburg steak, and I reflected with some satisfaction that the new onions in the garden are ready to be used for a meat garnish. But when she got through she did not sink on the earth in a pile of little pieces as I expected, but ran like a deer, bawling like a fog-horn, to where a calf that had been weaned the day before was bleating for its mother. By this time the red cow had become excited and was threatening to follow her fool daughter through the barbed wire fence. And the cow whose calf had been taken the day before also went into hysterics. I don't believe there was ever so much noise and ex- 


\section{THE FARROW COW AND OTHERS}

citement on the farm as there was for the next few minutes. The boy kept the red cow from going through the fence, and I opened the door of the drive-shed and hurled the calf under the buggy, where it lay down once more with a little grunt of satisfaction. Then I went after the farrow cow to see how much she was damaged. It seems incredible, but there was not a scratch visible on her silly carcase. Now, will some learned man please explain how that could be possible. Whenever I try to go through a barbed wire fence, even though I go at it with the greatest circumspection and care, the barbs catch in my hat, coat, trousers and stockings, and even catch the rag on my sore finger-not to mention the bias patches they tear out of the most sensitive skin in Middlesex County. And yet that cow ripped through that fence by brute force and didn't get a scratch that was visible to the naked eye. Before I got peace restored on the place I had to capture each cow and lead her into the stable. I had to put in the three of them before they would stop threatening to commit hari-kari on the barbed wire fence. As I think over the occurrence the lesson that sticks in my mind is that the farrow cow was wonderfully like a professional reformer. Though her 


\section{THE RED COW}

interests were not involved in any way she made a bigger disturbance and got more thoroughly worked up than the cow that was really bereaved. And nobody thanked her or gave her a word of praise. I admit that this lesson came home to me with great force.

Though I got the cows in the stable the excitement was by no means over. The cow that had lost her calf the day before is a kicker by nature, but after getting excited she simply refused to be touched when milking time came around. When she was being broken in last year sympathetic friends sent me many receipts for conquering a kicking cow, but in the state she was in none of them was of any use. Though I could keep her from kicking by tying a strap around her hind legs and another around her body in front of the udder, my friends neglected to tell what to do when a cow tries to lie down on top of the milker. But just when I was in the thick of this trouble an experienced milker came along and gave me a plan that was so simple that it seemed silly. I took off the leg and body straps and then took a rope and looped it loosely across the cow's back in front of the hip bones and then tied it be- 


\section{THE FARROW COW AND OTHERS}

hind so that the rope rested loosely against her knees. There was no pressure of any kind. The rope simply hung around her rump and lay against her hind legs. This plan had not been recommended by any of my correspondents, but it worked like a charm. She would lift her feet but would not kick and she gradually quieted down. Apparently that loose rope gave her much the same feeling that we humans have when our clothes begin to come undone in some public place. We do not feel like putting forth violent efforts of any kind. Anyway, it was the conquering scheme and I pass it along to all who may be having trouble with kicking cows. And the lesson to be learned from that is-Pshaw I forget just what lesson I was going to draw from the kicking cow.

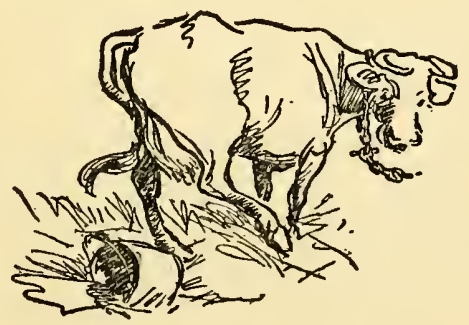




\section{IX.-Cow Enjoyment}

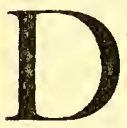

ID any one say that a cow has no sense of humour? I am not sure that any one did, but cows, as a rule, are regarded as very serious-minded. When Bill Nye tried to emphasise the fact that he could occasionally be serious, he wrote: "There are times when I can be as serious as a cow." He might also have written that there were times when he could be as happy as a cow having her will with a stack. Just let a cow get free swing at a stack and she can have more solid enjoyment than anything else on the farm. Up goes her tail, down goes her head, and she rushes at it as if she were going to pitch it over the moon. Then she will throw herself against it sideways and rub against it like a tom-cat in a catnip bed. If it happens to be a stack of sheaves, and she comes out of her merry bout with a sheaf hanging rakishly from one horn, she will look as happy as a woman coming out of a bargain-counter scrimmage with a new hat. As there is a stack between the stable door and the 


\section{COW ENJOYMENT}

gate of the pasture field the cows manage to have considerable fun every night and morning in spite of wild yells and the use of a buggy whip. Sometimes, when driving through the country, I see straw-stacks to which the cows are allowed free access, and most of them are so rubbed out at the bottom that they look like big mushrooms. I shouldn't wonder but it is a good thing for the cows, too. There is an old proverb which says, "Laugh and grow fat," and who knows but the cows might lay on beef more rapidly if allowed to enjoy themselves in this way. I offer this suggestion to the scientific department for mature consideration. Although they have done well, there may be a few tricks about beef-raising that may have escaped their attention, because they have been considering the matter so seriously.

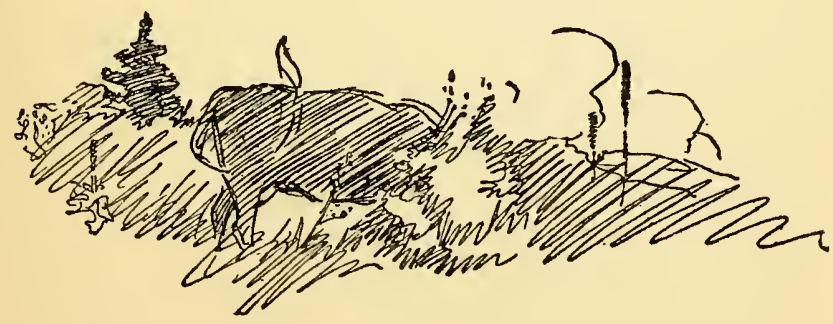




\section{X.-Cow Kaiserism}

7 EEDING a dozen head of cattle, watering them, cleaning out the stable, milking four cows twice a day and separating the cream take up a lot of time, and when the thermometer is hovering around zero it is none too pleasant. And besides the regular routine there are bound to be incidents that try the temper. For instance, when I was doing the chores one day last week, with the thermometer at six below, I cut the ice on the Government drain and turned out the cows to water. When I had finished cleaning the cornstalks out of the mangers and had put in a fresh supply of feed I noticed that only the red cow and her eldest daughter, who never leaves her side, had returned to the barnyard. An investigation showed the rest of the herd standing around the water-hole. I started down to find out what was the matter, and found the Jimmy-cow standing over the hole in the ice keeping the rest of the cattle away. She had her fill of ice-water and was shivering with cold, but she 


\section{COW KAISERISM}

was in possession of the visible water supply and was bound to show her authority, even if she fr-fr-froze. She got out of the way of the swinging kick I launched at her, and my leg almost pulled itself out by the roots. Such conduct on the part of a cow leads me to believe just the opposite to Gratiano, who was inclined
"To hold opinion with Pythagoras,
That souls of animals infuse themselves
Into the trunks of men."

I incline to the belief the souls of men infuse themselves into the trunks of animals, for it does not seem possible that by any process of evolution animals should develop such human meanness. I have often seen human beings play just such tricks as that cow played, and it strikes me as being of wholly human origin. In the same way I have always doubted the "dog in the manger" story. I have never seen the trick of keeping another animal from using something that was of no use to itself played by any dog of my acquaintance. The trait is wholly human, and can be accounted for only on a theory of transmigration. The Jimmy-cow must be occupied by the spirit of some gripping old miser, for she has 


\section{THE RED COW}

other traits that are entirely human. She is so discontented with her lot that she bawls whiningly even when she has her mouth full, and in that way contradicts a verse in Job, which I cannot locate this morning, which asks if the ox "loweth over its manger." If I can only manage to sell the Jimmy-cow to some back-to-the-lander next spring he will learn much by studying her exasperating little ways. 


\section{XI.-A Night Session}

THE cattle seem to suffer from insomnia occasionally, and the hot nights rouse their predatory instincts. Last night as I was gasping on the floor besides a screen door I heard something stirring on the lawn. Glancing out I saw one of the calves investigating a bed of poppies as if meditating a dose of laudanum to induce sleepfulness. Further investigation found all the cattle and the horses in the orchard. Dressing lightly and hurriedly, I called Sheppy and started to drive them out. For almost an hour we raged around the orchard and the buildings before we got the brutes back into the pasture. I found that the pasture gate was open and at once jumped to the conclusion that the boy who put out the cows after milking had left it open. While running around in the moonlight and under the shadows of the apple trees, getting tripped by furrows and switched in the face by branches, I thought of a number of interesting things to say to the boy about his careless- 


\section{THE RED COW}

ness. At first I intended to waken him and tell them to him while they were fresh in my mind, but when I got a drink of cold water at the well I thought better of it and decided to let the matter rest until morning. The evidence was all against him, for he was the last one through the gate, and as the gate was a new hardware-store gate of steel tubing and wire, with a regulation catch, I felt sure it couldn't have come open accidentally. But it was just as well that I decided to let things stand over until morning. About 3 o'clock, when I was again snoozing fitfully on my sofa-pillow by the door, Sheppy began to bark and a cow rushed past. They were in again. Without waiting to dress I joined Sheppy, and we took the Kneipp cure together while rounding up the cows and getting them back into the pasture. The new hardware store gate was open again, and my thoughts shifted to the hardware man. I pictured myself leaning over the counter and saying things to him about that gate and the fastenings on it. Yet that would hardly do. He did not make the gate; and, anyway, it was of the kind used by all other farmers. The real trouble was with the gifted Red Cow and her unhallowed progeny. I knew from experience that if there was any way of getting into 


\section{A NIGHT SESSION}

mischief they would know it. The gate fastenings that were good enough for listless and pampered pure-bred cows were no defence against their enterprising energy. So if any one was to blame for the night's trouble it was myself-for owning that particular strain of cows.

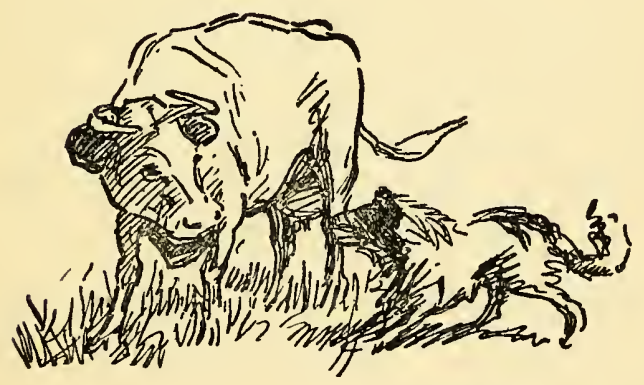




\section{XII.-A Calf Puzzle}

7 HE things that a spirited and energetic calf will do are beyond the power of an ordinary man to foresee or provide for. When the new stable was built the corner came within less than a foot of the corner of the granary. Of course it was intended to nail a board in the opening so as to make a complete shelter for the cattle in the winter, but somehow we never got around to doing it, and in the meantime the opening was handy for the children to squeeze through sideways. No one ever thought that any of the livestock, except the cats, would ever attempt the passage, and that mistaken idea almost cost us a calf. When the cattle were being put in last night one of the calves felt altogether too frisky to go in to be tied, even though the manger was full of choice hay. He ran away into the orchard, and when brought back made a break into the pasture field. When rounded up once more we were all on hand to shoo him through the stable door. A boy had him by the tail to steer 


\section{A CALF PUZZLE}

him straight, but at the last second he made a jump sideways, dragging the boy with him, and plunged head-first through the opening between the stable and granary. His head and shoulders went through easily, showing that he has the wedge shape valued by breeders, but his hip bones were too wide. When I reached him he had pulled through so that he couldn't be backed up because of his spreading ribs and couldn't go through all the way because of the hip bones. He was as firmly fixed as one of those bass-wood plugs the boys used to force through a board when boiled soft. They used to offer it as a puzzle, and ask you to get out the plug. It had been put in, so why couldn't it be taken out? When I examined that calf I almost made up my mind that he would have to be boiled before he could be taken out. At least he would have to be taken out in sections or we would have to move one of the buildings. Before taking desperate measures, however, I examined things carefully and decided that by prying a couple of the siding boards off the granary there was a bare chance that there would be room to get him through. This was done by the expenditure of much man and boy power, and he got through by a hair's breadth. In fact, I think it was a closer shave 


\section{THE RED COW}

than that, for there are hairs on the corners of both buildings. The experience took the foolishness out of him, and as soon as he was free he meekly allowed himself to be driven into the stable. And that reminds me that I haven't nailed a board on that opening yet. I must attend to it at once or one of the bigger animals will be trying the passage, and I shall have real trouble. 


\section{XIII.-Cow Character}

T $T$ is when a fellow settles down to do the chores twice a day and every day that he gets thoroughly acquainted with his livestock. When the cattle are in the pasture field they look pleasant and pose for their pictures when people come along with cameras, but when they are put in stalls and waited on hand and-I mean foot and mouth, they develop all sorts of little meannessesjust like human beings. One little cow starts to shake her head until her horns are simply a dangerous blur every time I go to loosen her chain to let her out to water. I have had several narrow escapes from being prodded, but it is useless to yell at her, or even to use the whip on her. She will start shaking her head as soon as I lay my hand on the chain, and she keeps it up until the chain drops from her neck. Another brute has the habit of swinging quickly towards me as soon as she feels the chain loosen, and I have to side-step like a prizefighter to get out of the way of her horns. But I 


\section{THE RED COW}

am glad to record that the Red Cow, variously known as Calamity and Fenceviewer I., can be untied safely, even by a child. When the chain is opened she backs quietly from the stall and walks to the stable door in a dignified manner--unless there happens to be a pail standing around where she can poke an investigating nose into it. She is always on the lookout for something to eat, and she always enjoys it better if it is something she should not have.

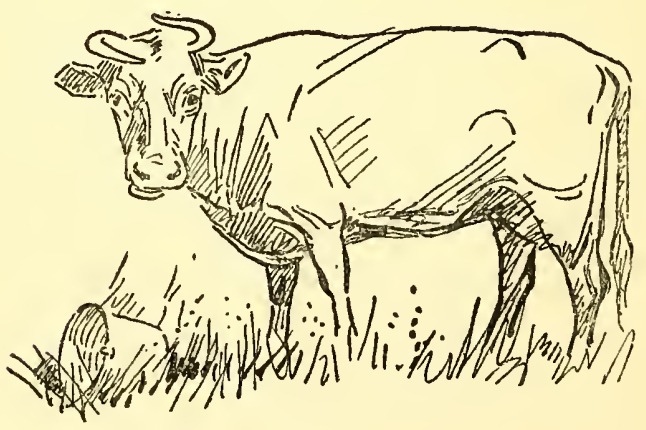




\section{XIV.-Calf Feeding}

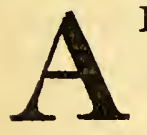

FTER all, it is the things that we see every day that are the hardest to see. Here we have been feeding the calves by a method of our own all summer withont realising that there was anything unusual or amusing about it. It was a city visitor who finally opened our eyes, or at least partly opened them, to the comedy of our calf feeding. Frankly, I can't see that there is anything very funny about it yet, but as he persists in throwing fits over it every time the calf feeding occurs I am going to describe it in the hope that some one else may get a good, health-giving laugh. All summer we have had three calves that came to the orchard fence twice a day to get their ration of skim milk and feeding flour. When feeding time came the pails of feed were placed beside the fence and the calves stuck their heads through between the wires and helped themselves. As the work settled down to part of the regular daily routine Sheppy was also taught to attend to one of the details. 


\section{THE RED COW}

As all who have had dealings with calves are aware, they will stand around for half an hour after feeding time and suck one another's ears in a vain attempt to get more nourishment. In order to break them of this practice it was Sheppy's part to wait until they had finished their meal and then scatter them to different sides of the pasture. The whole business became quite a matter of fact. Sheppy wouldn't bother the calves while they were waiting for their feed or while they were feeding, but just as soon as they lifted their heads from the pails Sheppy jumped for them, and with tails in the air they scattered over the pasture at no ordinary rate of speed. Our city visitor regarded it as the most remarkable combination of a quick lunch counter meal superintended by a saloon bouncer that he had ever witnessed. He would point out as well as he could between fits of laughter that the bouncer added to the free lunch counter was a wonderful improvement, and that he was going to recommend it to the managers of city cafeterias as soon as he got home. Such places sometimes get crowded at lunch hour by people who will linger over their coffee, but if an efficient bouncer were employed who would send them on their way as Sheppy sends the calves, fewer peo- 


\section{CALF FEEDING}

ple would have to wait in line for their "sinkers" and coffee. Moreover, the patrons would be startled into taking an amount of exercise that would probably help their digestion. Now you have the whole story and can decide for yourselves whether the city visitor had any cause for his unhallowed mirth. We certainly regard it as part of the daily routine, and Sheppy goes about his part of the work as solemnly as if the whole management of the farm depended on it.

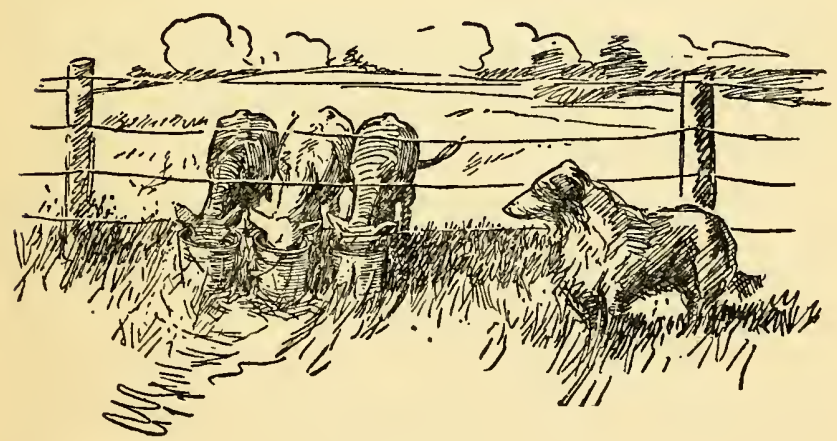




\section{$X V .-A$ Cow Trick}

T HATE to revive the old-fashioned cowpoke, but I don't know what else to do. Fenceviewer II., eldest daughter of the Red Cow, has discovered that even a wire fence can't stand the pressure of a little over half a ton of muscular beef. Part of the wire fencing on the farm is of a kind that was popular a number of years ago. It consists of seven strands of wire tightly stretched along the posts, with upright slats fastened every few feet. It is a presentable-looking fence, and for all ordinary purposes is entirely satisfactory, but this cow has discovered that by pushing her head through between the wires and throwing her weight against the fence she can break the wooden uprights and walk right through. The result is that unless she is watched she helps herself to apples in the orchard whenever she feels like it. She can go through the fence anywhere whenever she wants to. But, though the other cows see her do it, they do not seem to learn the trick. 


\section{A COW TRICK}

This convinces me that the Red Cow is not quite so intelligent as I thought. When her daughter pushes through the fence, and is helping herself to the apples, the red pirate sticks her head over the top wire and bawls enviously. Of course, as long as she approaches the fence in that way it turns her successfully. Fenceviewer II. pokes her head through about half way up on the height of the fence. When she pushes forward she is able to step over the lower wires, throwing the top wires over her back after the upright slats are broken. She shows some intelligence in the way she attacks the fence, but what interests me is that she knows enough to exercise her whole strength in getting through.

If our domestic animals once learned to use their strength in this way there would be no controlling them. They would cross the country, in spite of fences, like the new "tanks" they are using in battle. The little tricks of cunning the animals develop, such as throwing down rail fences and working gates open, can be defeated by a little care, but if they once learned how strong they are and the effect of their whole weight when thrown against an obstacle we would not be able to manage them. They could break through the walls of their stables, and no or- 


\section{THE RED COW}

dinary fence could withstand them. Of course, I know that if $\mathbf{I}$ put an old-fashioned poke on this brute it would probably beat her, because the pole in front would go under the lower wires and bring them against her chest, so that she would have to break the wires to get through. But pokes haven't been seen in this part of the country for years, and I am afraid that if $I$ made one and put it on this insurgent cow it would cause an awful lot of talk. Pcople going past in automobiles would see it, and they would talk also. As it is getting near the end of the season I shall get over the difficulty by keeping the cow in at night and putting her out to pasture in the daytime in a field that has proper woven fences. I know the poke would do the trick, but really, though you may not believe it, there are some things that I haven't the nerve to do.

When Fenceviewer II. is on her depredations she indulges in one cow trick that I should like to have the scientists explain to me. After she has eaten all the apples she wants she makes for the hay stacks and proceeds to root at them with her horns and to push herself along against them as if she were trying to knock them over. I have no doubt she does this 


\section{A COW TRICK}

to brush off the fiies and scratch herself pleasantly, but when I see her at it she looks to me to be enjoying herself in a way not wholly accounted for by the fly and itching theory. When attacking the stack with her horns she flings her tail in the air and prances as if she were trying a new tango step. Then she hurls herself against the stack and rubs along against it until she reaches the other end, where she throws up her head, with a wisp of hay on her horns, and looks as if she were enjoying life to the full. All cows will do this when they get a chance-at least all cows I have had dealings with. Perhaps purebreds that have their names in the herd book may be above such tricks, but I doubt it. Anyway, cows are the only animals that do this. I have never known horses, pigs or sheep to do it, though the flies no doubt bother them too, and they also must feel itchy at times. But if you let cows get at a stack they will rub against it until it looks like a monster mushroom. I have even known cows to keep on rubbing against a strawstack until the central stem got worn so small that the heavy top tumbled over on them, and they had to be dug out with much labour.

I wish some scientist who isn't busy would tell me 


\section{THE RED COW}

why cows go at stacks in this way. They didn't have stacks to rub against in their wild state, and I never see them rub against trees or buildings. And when the scientists are at it I wish they would tell me why it is that a horse when rolling seems to prefer a soft spot where he can get all muddy, so that you will have to put in an extra half-hour when currying him before driving to town.

Drat that cow! She must have known that I was writing about her and decided to give a demonstration. When I stepped out a few minutes ago I found her helping herself to apples from the lower branches, and as I had my mind on the present price of apples I didn't call to her to make herself at home or tell her that she was welcome. Quite the contrary. And when Sheppy and I started to put her out she made for the nearest haystack with a joyous little bawl and almost upset it as she ploughed along the side of it. I am afraid I must resort to a poke, no matter what people may think or say about it. And you may be sure that when any more fencing is done on the farm I shall use woven wire, or rather fencing that is fastened together without the use of brittle wooden slats. This cow will probably be a 


\section{A COW TRICK}

nuisance until we either sell her or put up new fences. She knows too much, and as she has inherited a full portion of her mother's impudence there will be no controlling her.

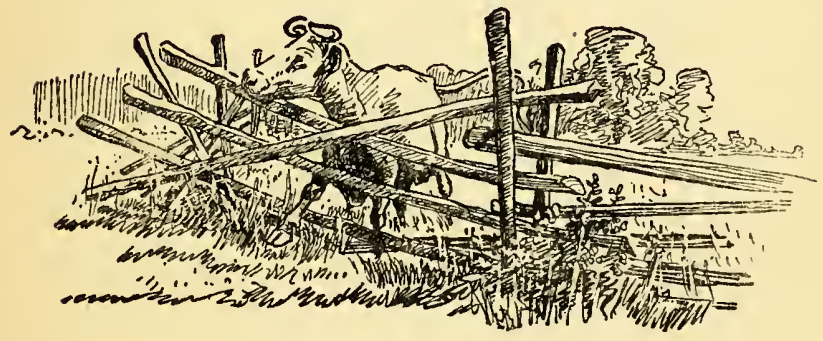




\section{XVI.-Cow Cussedness}

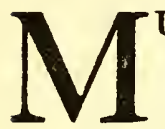

$\mathrm{UCH}$ as I hate to admit it, Fenceviewer and her tribe have me beaten to a standstillor, to be more exact, they have been keeping me on the run all the time. Some weeks ago I told how Fenceviewer II. had solved the mystery of the wire fence that is made of separate strands of wire strengthened by upright slats. She found that by poking her head through between the wires and throwing her weight against it she could force her way through wherever she wanted to. At the time I threatened to make a poke for her, but as it was the orchard she was breaking into the need for keeping her out disappeared when the apples were packed and shipped. But a couple of days ago the carrots and beets in the garden were dug and the red brute immediately took advantage of the fact that one side of the garden is fenced with slatted wire. After she had reached the carrots a couple of times I listened to advice and fastened a board on her face-a sort of wooden veil. 


\section{COW CUSSEDNESS}

Making cow-pokes is quite a job, and the art has been lost in this neighbourhood, where they have well-bred cows that lack ambition. But I was told that a board on her face would do the trick just as well. They did not know the Fenceviewer strain. After dressing her in her new costume I turned her loose and watched through a knothole in the driveshed. She walked straight to the fence near the carrots and began to experiment. The board bothered her, for she couldn't make a head-on attack on the fence, but it didn't bother her long. She soon found that by approaching sideways she could see well enough to swing her head between the wires and then push through. I interrupted her before she reached the carrots, and then Sheppy drove her to the other side of the field so that I could get time to cool off and think things over. But I didn't cool off. I had noticed that while the brute was working her way through the fence she was being watched by her mother, Fenceviewer I., the original red cow of the lot, but as the old pirate had not learned the trick sooner I did not think she would learn. Ten minutes later I found her at the carrots. It had finally dawned on her how the trick was done. I drove her out with sticks and harsh cries, but I had barely 


\section{THE RED COW}

closed the gate before she was poking through the fence again in the most approved manner of her daughter.

That settled it. I rounded up the flock and drove them into a field that is surrounded by woven wire fences and left them there. The pasture doesn't amount to much, but it is not likely that the weather will make it possible for us to pasture them more than a week or two longer, so they will have to be given extra feed night and morning and have their run confined to the cow-proof field. Next year, if they have not forgotten the trick, they will have to be sold or I will be forced to put up new fences such as would not be needed for reasonable and rightminded cows. 


\section{XVII.-Teaching a Calf}

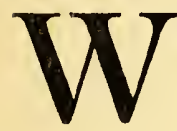

HEN I got home I found a fresh calf waiting to be taught how to drink out of a pail. Now that several days have passed, I feel that I can mention the subject in proper language. Breaking in young calves is just the same job now as it was when the world was young. I dare say there is really nothing new that one can say about it, but there seems to be a sort of relief in saying some of the same old things over again. This is a particularly lusty and likely calf, grandson of Fenceviewer I., "that serpent of Old Nile," familiarly known as the Red Cow. He proves that there is something in the law of atavism, for he takes after his unregenerate and belligerent grandmother rather than after his gentle, though somewhat sneaky, mother. Anyway, when I took the pail of milk and started in to nourish him I found him more stiff-necked than a Cabinet Minister. Still, the line of apprcach was better. I straddled his neck and pushed his head into the milk so that he 


\section{THE RED COW}

was forced either to drink it or inhale it. One could hardly treat a Cabinet Minister in that way, much as he would like to. But to our calf. Once more the lesson has been forced on me that when feeding a calf one should not be arrayed in the glory of Solomon, or in other words that he should not wear the clothes he wore to the city especially if he ever expects to wear them there again. Even a commodious pair of overalls is not a sufficient protection. The boy who was hovering on the outskirts of the trouble and pretending to help was properly dressed for the occasion in a three-piece suit-shirt, pants, and one suspender. When that calf gave a sporadic bunt that squirted milk into my eye and variously plastered me, I wanted to give him a six months' hoist with the toe of my boot, but I restrained myself. (You will notice that Parliamentary phrases stick in my vocabulary after a visit to Ottawa.) However, I am glad to report that the calf is now so much subdued that the boy in the three-piece suit is able to attend to him. 


\section{XVIII.-Calf Exuberance}

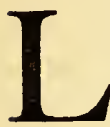

AST night Juno got loose, and for a few minutes there was excitement around the stable. Juno is a fall calf, daughter of Fenceviewer II., and owing to the scarcity of stable room she is being pampered and fed up for veal. At the time of her arrival the children named her Jupiter, but on second thought it was considered that Juno would be more appropriate. Up to last night she had lived in a small calf pen at the end of the stable, but the fastening on the gate came loose and she discovered what her legs were for. She shot out through the stable door in a way that sent the hens flying over the hay stacks. Then she tripped over a sheaf of cornstalks that I had dropped on the ground while preparing to feed the cows, sprawled at full length, bounced right up and rushed ahead until she was brought to a standstill by a wire fence in a way that almost telescoped her neck into her body. Finding that the wire fence 


\section{THE RED COW}

would not yield she said "Bah-wah" and started in another direction. Sheppy was coming around the corner of the granary in his most sedate manner, when the pop-eyed avalanche almost stepped on him. When last seen Sheppy was plunging blindly between two haystacks with his tail between his legs. A flock of hens that were enjoying their evening bran mash next attracted her attention, and she made an offensive straight at them. When they were thoroughly scattered she rushed the ducks from a mud puddle, and the squawking they made startled her so that she applied the brakes and threw on the reverse. It was a wonderful exhibition of vitality, and showed what a milk diet can do for one. The next I heard of Juno was when I was stooping over to pick up a sheaf of cornstalks, and if you can picture to yourself a dignified man in that attitude with a lusty calf prancing behind him and going through the motions of getting ready to bunt you can understand the joyous laughter with which the children shouted a warning. I sidestepped in the nick of time and shooed Juno away to the orchard, where she could enjoy herself without getting into trouble. After the chores were done $I$ took a pail that was as 


\section{CALF EXUBERANCE}

empty as a political platform and she followed me right back into the pen just like an intelligent voter. I could do a little moralising right here, but it is not considered good form to talk politics just now.

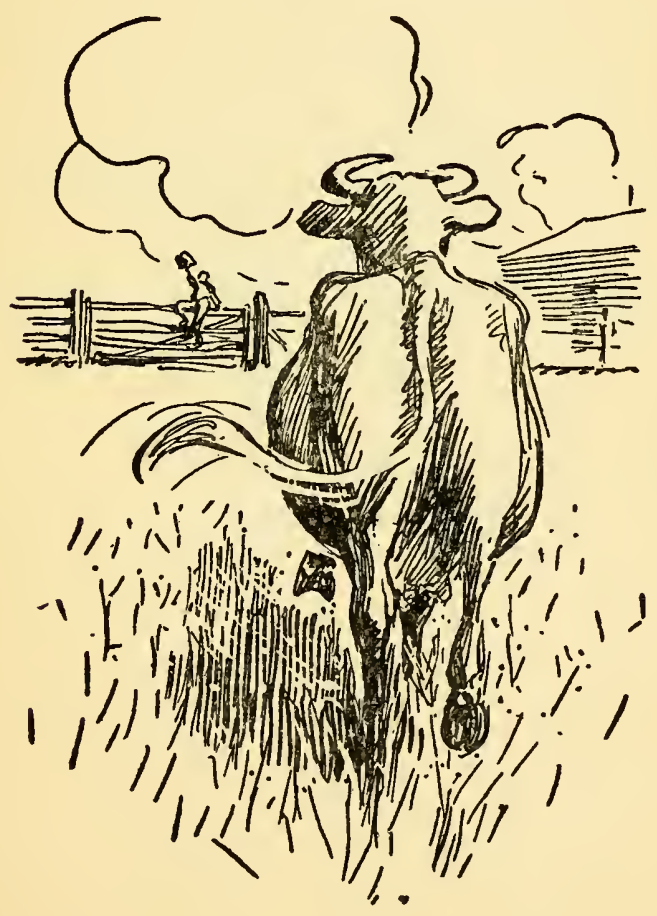




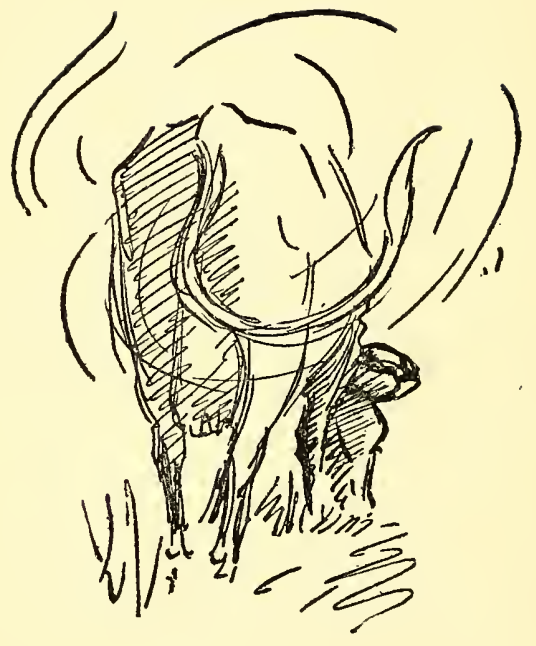




\section{SHEEP}




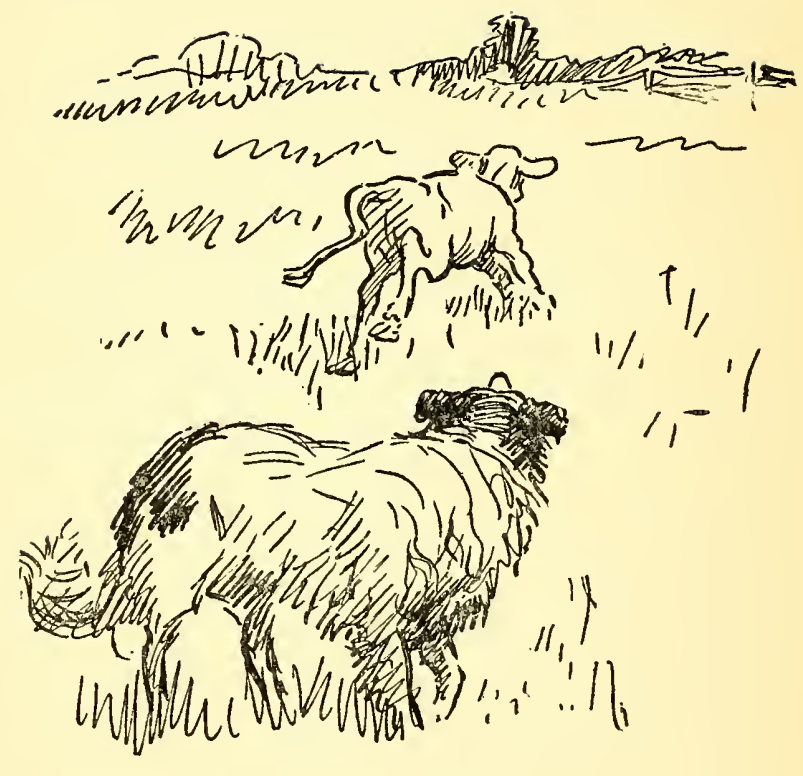




\section{XIX.-Our First Sheep}

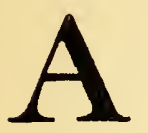

GREAT event has happened on the farm. Obeying the urgent appeals of the Food Controller, the littlest boys decided to go into sheep-raising. Having ideas of $\mathrm{my}$ own about sheep, I did not presume to advise them in their plans. If $I$ were going in for sheep my inclination would be to invest in the old pioneer variety that were half goat and half greyhound. Those sheep were entirely capable of taking care of themselves. You never had to worry lest they should get cast in a furrow. They were much more likely to get marooned on the ridge pole of the barn while pursuing some of their adventures. Fences meant nothing in their lives, and no matter where they strayed you could trust them to "come home, bringing their tails behind them." But so many scientists call to see us that even the children are getting high-toned notions and nothing would do them but properly registered, pedigreed sheep from a prize-winning flock. They made their own negotiations, drew their 


\section{THE RED COW}

savings from the bank and started into business with four ewe lambs. My first active interest in the new venture occurred when the sheep were brought home. I was called out to help get them into the sheep pen that had been built for their reception. When I appeared on the scene the sheep all had their backs to the door, and in their eyes there was an expression that suggested the popular song: "Where Do We Go From Here?" It was quite evident that they had no intention of going through the door. As we crowded in on them I spread myself out so as to cover as wide an area as possible, feet well apart and arms outstretched. I am not exactly clear as to what happened, but the sensation I had was that one sheep went under each arm, one between my legs and the other over my head. Anyway, by the time I had recovered my scattered wits they were in a far corner of the orchard, bleating pathetically.

The children rounded them up once more, while Sheppy, though a thoroughbred Collie, hovered around wondering what these creatures were. I don't believe he ever before had a close view of a sheep, but if Darwin is right, he would very soon show inherited instinct, and know just what to do in order to 


\section{OUR FIRST SHEEP}

handle them. But the children had no faith in Sheppy. They threw clods and told him to "go home, sir!" which he did in a humiliated manner. As the sheep were again approaching the pen I had a chance to observe their startling efficiency in the control of burrs and weeds. I have been assured that if we had kept sheep the farm would have been in a much tidier condition, and I am inclined to think that the statement is true. One of the sheep, on its way back to the pen, saw a well-loaded burdock that had been overlooked. It stopped to nibble a few burrs, and when it was shooed on, it didn't stop to walk around the obstruction. It simply walked straight over it, and when it had passed there was not a burr left on the stalks. Every solitary one had been caught in the sheep's wool, much to the disgust of the youthful owners, but I felt a certain amount of relief, because there is now no danger that the neighbourhood of that burdock will be seeded down for next year. It appears that what the sheep do not eat in the way of burrs they gather in their wool, and in that way clean up the farm. I am not quite sure that the scientists will approve of this method of weed control, but that is how the matter stands at the present writing. After several attempts at driving the 


\section{THE RED COW}

sheep into the pen we finally decided to corner them and catch them one by one. This was done, and the perspiring family was presently in a position to take a good look at the little flock in their pen. Far be it from me to dash the optimism of the youthful shepherds, but I could not bring myself to verify the belief that triplets are almost as frequent as twins among lambs. Still, wool promises to be a good price and the speculators stand a good chance of realising on their venture. Best of all, they will be helping the work of food production, which is now so urgent.

The human inhabitants of the farm were not the only ones that were interested in the advent of the sheep. The young cattle ran for their lives when they saw them, and you could hear the colts snort for at least a mile. The Red Cow did not get excited but she bestowed a disdainful glance on them that reminded me of the lady in Tennyson, who

"Stretched a vulture neck

And shot from crooked lips a haggard smile."

She is too blasé to get excited about anything except another cow, with whom she might have to fight 


\section{OUR FIRST SHEEP}

for the leadership of the herd, but she shewed in every line of her face and form that sheep were something new to her and that she didn't think much of them. The colts were the most excited of all. They ran around the sheep in large circles, snorting and shying. Whenever they crossed the tracks of the sheep they seemed to catch the unaccustomed scent like hound dogs and their excitement increased amazingly. Finally they got the sheep frightened, and in order to prevent trouble, we had to put the colts in another field. Though several days have passed the colts do not seem to get used to their new neighbours, and they snort with terror whenever they have to pass the sheep pen. It is quite evident that they cannot be allowed to run together for some time.

The arrival of the sheep on the farm caused me to give them some attention, and the more I meditate on them the more I regret that we did not go in for sheep-raising long ago. They have opened to me an entirely new field for articles. I had never realised how completely and intimately sheep are bound up with the history and literature of mankind. In ssymbolism they date back to the earliest chapters of 


\section{THE RED COW}

Genesis. It might even be shown that we owe much of our civilisation and learning to the care of sheep. Shepherds have been poets since the time of David and earlier, and they have even figured among the rulers of the world. The Biblical patriarchs were all shepherds, and in the history of Egypt we have the Hyksos dynasty - the fierce shepherd kings, who ruled, I think, for six hundred years. One has only to let his mind wander over literature and art to realise that man and sheep have been companions from the dawn of history. Pastoral poetry is a distinct branch of literature, and what would landscape painting be without woolly bunches in the middle distance to represent sheep? I understand that it is to the shepherds we owe the sciences of astronomy and algebra, and they have also made contributions to medicine and botany. It was of a shepherd that Touchstone said: "Such an one is a natural philosopher." Perhaps the most up-to-date contribution to civilisation that we owe to the shepherds is the ancient and royal game of golf. It began with the shepherds who whiled away their hours knocking about a woollen ball with their shepherd's crook. Assuredly the sheep will furnish me with an ample 


\section{OUR FIRST SHEEP}

field for research, investigation, experiment and nonsense of all kinds. I may even be able to get some political hints from them, because of their habit of following a leader. I look forward to a pleasant and profitable winter studying the children's sheep.

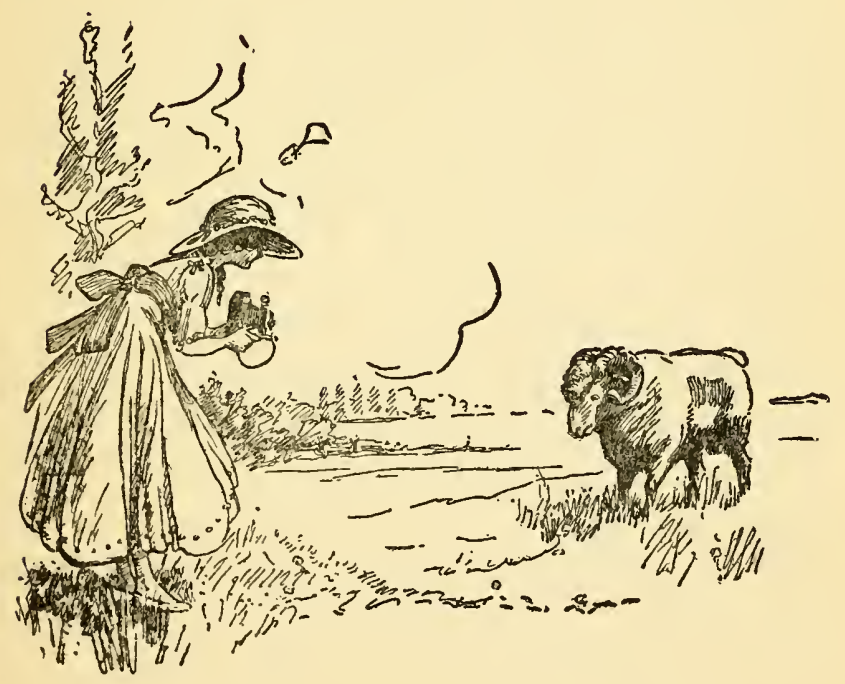




\section{$X X$. - The First Lamb}

T $\mathrm{N}$ spite of the persistent cold weather there has been enough excitement on the farm to send up the temperature several degrees. One day last week, when the mercury was sulking at zero, three lambs arrived on the place. Alas only one survived, in spite of tender care and the best advice of all the experienced sheep-raisers in the neighbourhood. One died at once and another followed a few hours later, though it was carefully fed and tucked in a warm nest beside the kitchen stove. The mother sheep could not be induced to take any interest in the weakling. One of her lambs was strong and vigorous, and to it she gave her whole care, seeming to know by instinct that nothing could save the others. And it is doubtful if she could have saved the one we have if we had not shared the cares of motherhood with her. At nightfall the thermometer went down and down until it reached 12 below, and the new lamb began to lose interest in this cold world. The frost penetrated to the snug box- 


\section{THE FIRST LAMB}

stall, and the poor little lamb shivered and refused to pay attention to its mother. She pawed at it to make it get up, but it couldn't get on its feet. So we wrapped it in a horse-blanket and took it to the nest beside the stove. For the next couple of days we kept it warm and carried it to its mother for brief visits at meal times. In that way we kept it from being chilled to death, and now that the weather has moderated it is living with its mother and being much admired. But I am afraid that some of the interest taken in it is rather sordid. When the excitement was at its highest I found a boy studying the market reports. He was looking up the price of wool.

Like all the other live stock on the farm, the lamb has a name of its own. Its owner informed me that it is to be called Mary Belle. Why he was so superfluous as to give it two names I did not inquire. The name sounded good to me-the sound of it reminded me of how :

\section{"Winking Mary buds begin}

To open their golden eyes,

With everything that pretty bin_-" 


\section{THE RED COW}

Mary Belle-Mary buds. There is a distinct assonance, but it is a slim one on which to hang a quotation. Still, the "Mary buds" reminded me of spring-and that led to results. Lambs are always associated with spring in literature, and why shouldn't they be in fact? My personal recollections of lambs all coincide with days:

"Whan that Aprille with his showres soote, The droghte of Marche hath perced to the roote."

So what on earth was a lamb doing in this world in January? On inquiry I learned that one must expect such things if he goes in for pure-bred, pedigreed sheep that may take prizes at the fall fairs. Any lamb that is born after 12 p.m. of December 31 of the preceding year is entitled to rank as a spring lamb. When the fall fairs come round Mary Belle will have the advantage of several months' growth over the lambs that come in the springtime"the only pretty ring time." This makes it look to me as if prize-winning were rather more important than sheep-breeding. Poor Mary Belle will have to spend the most frisky months of her life in a little pen, instead of skipping about among the flowers, as a lamb should. She is being robbed of her youth in the hope that she may win a blue ribbon. 


\section{XXI.-Sheep Surgery}

T THEN I got home from the village a couple of evenings ago a bareheaded delegation met me at the road gate with bad news.

"Strafe's leg-was chased by a dog-was broken -and I must set it-Oh, the dog was a strangerStrafe couldn't "'

At least that is what it sounded like. One thing is certain, and that is that two excited boys can't tell a bit of news as quickly as one. After both had blown off steam at the same time, I questioned them and found that Strafe, one of the twin lambs, had his leg broken. It seems that a stranger dog followed one of the children from the village in the afternoon, and in spite of being told to "Go home, sir," he persisted in following. But he no sooner reached the farm than he began chasing the sheep. To escape him they rushed to the barnyard, and as the gate was only partly opened they got jammed, and poor little Strafe, in spite of his warlike name, had 


\section{THE RED COW}

his leg broken. The dog was promptly chased away. None of the family had seen him before, and they did not know who owned him. Evidently he was a stranger. I was distressed to hear the news, for there is something so gentle about lambs that one hates to think of them suffering. In spite of his belligerent name, Strafe is an unusually gentle creature that is ready to stand and be petted whenever any one is in the humour to fuss with him. It almost seemed as if one of the family had been hurt.

My first thought was that the lamb might have to be killed to put him out of his misery. That is what usually happens to a colt that gets his leg broken, and having heard of several that had suffered in this way-or was it that they had a tendon cut on a wire fence?-I began to see the gloomy side of the matter at once. Still, on second thought, I reflected that a lamb with a limp might raise just as much wool and mutton as one with the use of all his legs, but it was quite evident that his prospects of figuring in the blue-ribbon class at the Fall Fair were probably ended. This was quite a calamity in itself, for he is purebred and the children had hopes 


\section{SHEEP SURGERY}

of him. As quickly as possible I got to the sheeppen and looked over the little patient. He was lying down in a comfortable attitude, though it was easy to see that his leg was broken below the knee, as the crook in it was quite noticeable. He made no objection to having me examine his leg, though it must have hurt to have the broken bone handled. What surprised me was that there was no evidence of swelling, though the bone had been broken for some hours. Another strange thing was that the bones lay so loose. The parts barely touched each other, though in cases of human fracture the bones sometimes get drawn past. It was no comminuted fracture I had to deal with, but a very simple case of simple fracture. Of course, the whole family gathered around to make comments and give advice, and I quickly found that I was expected to play the surgeon and give Strafe a leg that would be as good as new. Though surgery had never come within my experience in the past, I felt that this was no time for false modesty, and prepared for action.

While making inquiries among persons of experience as to the best way to proceed, I brought out 


\section{THE RED COW}

the curious bit of information that surgeons use only three splints when setting a human broken leg. My own instinct was to use four, but being assured that the doctors use only three I felt that there might be some mystic reason for it that was beyond the lay mind and made my preparations accordingly. Strafe had been placed on a bench, where he lay quite composedly while I took his measure for his new set of splints, which $I$ was whittling from a shingle. Apparently he was not a bit frightened or distressed. Judging from his appearance he seemed to think he was coming in for an extra lot of petting from the boy who was holding him, and he seemed to be enjoying himself. Finally, I got my splints ready, packed a bunch of loose wool around the broken leg and then began to wind a cotton bandage around my somewhat clumsy looking attempt at surgery. A visitor held the bones straight while $I$ was doing this and Strafe did not struggle a particle. Evidently a lamb's sense of pain cannot be as acute as that of a human being. Though $I$ was as gentle as possible I am sure that my touch was clumsy and that a broken bone in the human body if handled so inexpertly would have caused acute suffering. The lamb neither struggled nor protested, but allowed 


\section{SHEEP SURGERY}

me to move the leg about and do what I liked with it. After it was carefully bandaged he was set down on the ground, and hopped away on three legs to where his anxious mother was waiting for him. Yesterday he was feeding as usual, and as the splints were firmly in place $I$ am hopeful of a perfect cure. By the way, I wonder if they give prizes for animal bonesetting at the Fall Fairs. I must find out. 


\section{XXII.-The Patient}

THE progress of Strafe, the lamb that had his leg broken, is about the most surprising thing $I$ have seen in a long time. One naturally thinks of a broken leg as a serious thing, and it is to a human being, but it doesn't seem to cause so very much discomfort to a lamb. Two days after the accident I saw him taking part in a brisk game of "King of the Castle" with Clarissa and Mary Belle. Of course he was hampered by his game leg, which was bound up in the splints I had put on it, but he found little difficulty in climbing to the top of a pile of hay that had been thrown from the top of a stack and defending his position against assaulting forces. Though he carried his leg in the air he could still bunt vigorously, and though he sometimes got knocked over, he would immediately return to the fray. Evidently the nervous system of a lamb is not so sensitive as that of a human being. A child with a broken leg could not be taking part in games so soon after the accident. Although 


\section{THE PATIENT}

it is only a week since he was hurt I notice that he is already using his leg, though with a very decided limp. It is still too soon to take off the splints, so I cannot tell whether my attempt at bone-setting has been a success, but folks of experience who have looked at him assure me that his chances of figuring in the blue-ribbon class are ended. It will be his destiny to figure as mutton. This is not only a disappointment, but a considerable loss. 


\section{XXIII.-Shearing}

7 HE sheep changed their flannels this week and as the weather changed at the same time, I am afraid they are not feeling very comfortable. With wool at present prices, they were given a very thorough clip, and in spite of the pleasant proverb the wind has not been tempered to them. We have had the reliable north wind with which we have become quite familiar this spring, and I was sure they would catch their death of cold. I investigated to see that we had a proper supply of mustard and goose-oil in case I should have to put plasters on their chests and give them the proper dosing. But up to the present writing they seem to be doing very well, though they keep on the lee side of the buildings and of the hedge that runs along the road. They almost look uncanny in their present condition of undress. It is surprising to see what a small sheep emerges from the fleece when the shearing is done. The mother sheep look very little bigger than their lambs. By the way, as those lambs 


\section{SHEARING}

already have noticeable fleeces, I am afraid the warm weather will be rather hard on them. One warm day last week I noticed Mary Belle, with her mouth open, panting after a short run. What will it be like for her in August, when we have real heat? While speaking of the lambs, I am glad to report that my attempt at bone-setting proved fairly satisfactory. Strafe is able to gambol about much as usual, though he limps a little and is thinner for his experience. There is a lump on his leg where the bone knit and those who speak with authority say that although he is a fine lamb he must now be considered in the mutton class. But I am proud of the fact that my efforts preserved his leg for everyday use if not for show purposes.

As this has been the first sheep-shearing we have had on the farm in many years, I was interested to note the improvement. When the boys brought word that the shearers had arrived and were shearing the sheep I hurried to the barn to view the operation. As I approached I heard a sound like that of a cream separator, and was surprised to find that the shearing was being done by machinery. With these tame, modern sheep shearing is not the exciting 


\section{THE RED COW}

process it used to be. The legs of the creatures were not tied up in a bunch with a hame-strap to keep them quiet. The shearer merely made the sheep sit on her hind-quarters, while he tucked her head under his arm. He had a contrivance that looked like a small mowing machine, and was busily cutting swaths of wool along her sides. It was doubtless a great improvement on the old shears-the kind that memory associates with boyish haircuts. I have always thought of the shears by its Gaelic name, but it is past my power to spell it. It was imitative of the sound made by the shears when in use. If you take a pair of shears, close and open them and then try to pronounce the sound you hear, you will have the Gaelic name. It sounds something like "dwnguist." Pronouncing it is just as hard as it looks. One needs to be born to it. I found that they had an old-fashioned shears with them to clip off spots that the mower could not be put over safely, but it was very little used. I noticed that the new method of shearing leaves the sheep free from the ridges that used to be prominent features of old-time shearings-and haircuts. I shouldn't wonder but they could cut hair with these 


\section{SHEARING}

new machines, but as I have never seen anything like them in even the most up-to-date barber shops they cannot be practical for hair-cutting. But they are certainly the proper caper for sheep-shearing. 


\section{XXIV._V Vain Regrets}

TOHN MILTON was a noble poet, but he was not a safe guide in matters pertaining to animal husbandry. For the ordinary man, the bulletins of the Department of Agriculture are safer reading than the masterpieces of literature. If it were not for John Milton I might to-day have a bank account that would outshine "the wealth of Ormuz or of Ind." Just listen to this piece of foolishness that $I$ have been cherishing all these years:

"Alas! what boots it with incessant care To tend the homely, slighted shepherd's trade, And strictly meditate the thankless muse?"

You couldn't cxpect me to go in for sheep-raising while giving that quotation a place of honour in my memory, could you? The boys, not caring for poetry, and caring much for the practical bulletins, obtained my permission to go in for sheep-raising. Remembering the kind of sheep we had when I was a 


\section{VAIN REGRETS}

boy, I thought they wouldn't be much trouble, as they would pasture most of the time with the neighbours anyway. But the boys didn't go in for that kind. They got pure-bred registered sheep, and started under the best auspices, with a little flock that was partly bought and partly taken on shares. I admired the addition to the farm live stock, but did not get excited. These quiet, plump sheep did not seem to promise adventure of any kind. The sheep I used to know were more like Ancient Pistol's "damned and luxurious mountain goat" than they were like these pampered pets of the show-ring. Of course. I recorded the arrival of Mary Belle and Clarissa and Strafe, and told something about their doings, but felt no inclination to take up "the homely, slighted shepherd's trade." And now see what has happened. Last week a buyer of fancy sheep came along, gave the flock the once over, and then bought Mary Belle. When they told me the price he was paying, my wrath against John Milton boiled over. "Slighted shepherd's trade," indeed! That buyer paid sixty-five dollars for Mary Belle! You could have bought a whole flock of the sheep I used to know for that price. Why, $O$ why, didn't I go in for sheep when I came back to the land? 


\section{$X X V .-$ Sheep Sculpture}

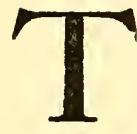

THERE are no such sheep as those that take the prizes at the Fall Fairs and have their pictures printed in the papers. I never believed that such sheep really existed, "so large and smooth and round," and now I know that they do not. At least they do not exist as a natural product of the farm. They are just as much a manufactured article as the little woolly "baa-baas" in the baby's Noah's Ark. I know this, because I saw a show sheep manufactured. When Mary Belle was sold it was stipulated by the buyer that she was to be clipped before being delivered. In my innocence of the guile of the show-ring I thought that this meant that she was to be trimmed a little around the edges so that her little fleece wouldn't look too ragged and ill-kept. When an experienced showman came to do the clipping, I naturally stuck around to see what would happen. I knew Mary Belle was a pure-bred sheep of some kind, but I thought it 


\section{SHEEP SCULPTURE}

was an ordinary kind. I had seen sheep and lambs in pasture fields that looked much like our sheep, so I did not think there was anything unusual about them. I supposed that the show sheep, with their wonderful points, must be specially bred and must belong to kinds that do not run in ordinary mortal pastures. But I know better now. I saw Mary Belle transformed from an ordinary playful scamp of a lamb to a primped and perfect darling of the showring. I have learned that sheep-raising and sheepshowing are two entirely different things, and I have been forced to the conclusion that Touchstone's shepherd didn't know much about the possibilities of shepherding. He was only a "natural philosopher," but the modern shepherd is an artist. I suppose it wouldn't do for me to say "fakir."

When Mary Belle was captured she acted much as an untamed youngster might when about to have his hair combed and neck washed before being exhibited to company. She jumped wildly and blatted for her mother, but it was no use. A strong man held her by the wool around her neck, while the experienced showman looked her over with a critical eye. He admitted that she had many good points-but there 


\section{THE RED COW}

were a few little things-still it didn't matter-they wouldn't show when he got done. After these cryptic remarks he took a couple of carding combs-I am not sure that that is the right name, but they were the kind of thing $\mathrm{I}$ used to see in my youth in the hands of old pioneer women who carded their own wool. They look like curry-combs. They are made of wire teeth, set in leather on a wooden frame. They look and feel something like a cockle burr. Anyway the showman took these instruments and started at Mary Belle's fleece. The process was much like combling a particularly snarly head of hair and was received in the same spirit. The lamb jumped and called for mother, but as I did not regard the operation any more cruel than many a hair-combing I had witnessed I did not protest. With these carding combs the lamb's fleece was all pulled out so that she suddenly looked twice her usual size. But there was no improvement in her appearance. In fact she looked shaggier than ever. But presently her wool was all pulled out on end, and into separate strands, and the real work of trimming or clipping was ready to begin.

Taking an especially sharp pair of shears, the showman tried their edge on his thumb in quite the 


\section{SHEEP SCULPTURE}

old shepherd manner that I could remember from earlier days, and looked over the unkempt mass of wool before him with a critical eye. Though I didn't realise it at the time, his attitude was much the same as that of Michael Angelo before the mass of marble from which he hewed his David or of Canova when he stood before the lump of butter from which he carved the lion. The showman was really a sheep sculptor, and he was going to snip and clip a prizewinning lamb out of the mass of wool before him. With a sure hand he mowed a slight swath of wool along Mary Belle's back. Where there were humps he cut fairly deep, and where there were depressions he skimmed lightly. The result was a back-line that was as smooth and straight as if cut to a ruler. Swiftly but carefully the shears went snipping along her back and down the sides. What surprised me most was the surface left by this skilful shearing. It looked like a fine felt. If I didn't know better, I would say that the lamb had been clipped right to the skin. Yet there were probably two inches of wool under that deceiving surface in some places. The sculptor proceeded with his work with artistic sureness of touch. He had in his mind an ideal lamb, 


\section{THE RED COW}

and he proceeded to cut to that ideal. As he worked there began to emerge just the kind or lamb one sees in the show ring or pictured in the agricultural papers. The new lamb was not the harum-scarum Mary Belle in any sense of the word. She looked twice the size, and her smooth coat, entirely free from snarls and elf-locks, made her look as fat as a seal. I had to poke at her new coat in order to convince myself that it was not really a convict-clip, right close to the skin. The surface seemed to show the movement of the flesh underneath, and her sides palpitated to every breath, just as if there was no covering of wool.

As the expert worked she took on a wonderful smoothness and roundness. Her hams looked like legs of lamb such as had never been. Her back became broad and plump and her breast was a delight to look at. I watched admiringly while an entirely new Mary Belle was carved from the raw material of the old. And the strange thing of it was that she seemed to like the transformation. Before the work was half done there was no need of a strong man to hold her. She stood with her chin resting in the showman's hand while he snipped and clipped her to shape. Finally he turned her over to 


\section{SHEEP SCULPTURE}

the other man to hold and then stood back as a sculptor might to view his work. He walked around her and looked her over from every angle-occasionally stepping up to trim some point to a more desired shape. When she was finally done I half-expected him to go over her with a piece of sandpaper, but that was not necessary. The shears had left her smooth enough. When the art work was completed she looked exactly like the impossible sheep they have at the shows and she seemed proud of the change. She stood to have her picture taken just like a belle who was dressed for some grand occasion. Her nature seemed to undergo a transformation as well as her figure. I could not imagine her romping and playing king of the castle with Strafe and Clarissa. In fact, I doubt if her mother would have known her when she was turned back into the pasture if it were not that sheep know their offspring by the sense of smell. Everything was changed about her except her characteristic odour. She looked to be fully as big and much heavier than her mother, who had recently been subjected to a skin-tight shearing. As I looked her over I felt that the time had come to add another stanza to the many parodies of "Mary Had a Little Lamb": 


\section{THE RED COW}

Mary had a little lamb-

They took her to the show,

And though she had a perfect shape

It really wasn't so.

After seeing her in her finished form $I$ have no doubt that Mary Belle will win prizes in the show ring, but I feel that the prizes should not go to her, but to the sculptor who fashioned her. She is more of a work of art than any of the lambs and sheep we see in pastoral paintings.

P.S.-I almost forgot to tell that the showman enlightened me on another trick of the prize-ring. While I stood behind Mary Belle he caught her under the chin in such a way that her back and rump looked broader and fuller than ever. Then as I walked around in front of her he changed his position and with a skilful flick of his toe separated her feet so that she stood with feet well apart. This made her breast look broader and plumper than any breast of lamb could possibly be. All of which made me wonder if the fall fairs influence sheep-breeding as much as they do the art of sheep-showing. I wonder if all the other animals of the show-ring are handled in the same expert way. 


\section{XXVI.-Our Lawn Mower}

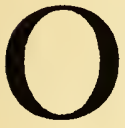

NCE more opportunity has knocked at my door and I failed to take advantage, and now it is too late. When the lamb had his leg broken he and his mother and sister were kept in the orchard, so that he wouldn't have to run about so much. The orchard includes the lawn around the house, and as the spring advanced the lawn naturally was the first spot to offer inviting pasture. The result was that the sheep came right up to the door to nibble the young and juicy grass. Mary Belle pushed her way through the fence so that she could be with her young friends and the flock were able to make quite a showing in their attacks on the grass. I was not long in noticing how well they did the work that I usually have to do with a lawn mower, and I saw where I could have some freedom from this irksome task this summer, simply by turning the sheep to graze on the lawn from time to time. From this discovery it was only a logical step to think of having the sheep 


\section{THE RED COW}

patented as lawn mowers so that any one who used my idea would be obliged to pay me a royalty that might grow to such proportions that it would attract the attention of the Minister of Finance. It was a beautiful idea, for if I could only get all the lawns in the country paying tribute to me there would be no end to my income. But while I was talking about it and telling people how they could sit around wearing diamonds when I made my fortune by my new idea the papers brought the news that President Wilson had just bought a dozen Shropshire sheep to clip the lawn at the White House. This makes the great idea public property. It is too late to get a patent on it now. Still there is some satisfaction in remembering that great minds run in the same channel. The busy President has hit on the same trick as I have to get out of the tiresome job of running the early-rising lawn mower. 


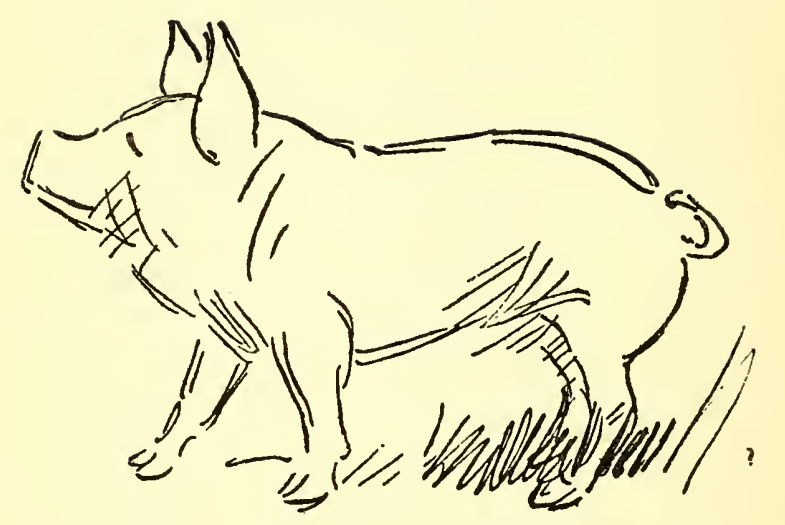




\section{$\boldsymbol{X} \boldsymbol{X} \boldsymbol{V I I} .-C l e m e n t i n e$}

V $\mathrm{N}$ spite of the prevailing atmosphere of laziness there is one brisk thing on the place. Clementine, the pet pig, broke out of her pen this morning, and as the children are at school she is allowed to roam at will. She is positively brisk in hustling for apples in the orchard and for heads of oats around the oat stack. And wherever she goes Sheppy follows her, growling and barking. He knows that she should not be running loose, but he hasn't the courage to put her in her place. There were no pigs about when Sheppy was receiving his somewhat skimpy education, so he doesn't know what to do with Clementine. Apparently she understands this, for she pays no attention to him except when he gets too tiresome with his barking and growling. At such times she opens her mouth and runs at him, and Sheppy almost falls over himself in his attempts to get out of the way. Of course, it looks absurd to see a big dog running out of the way 


\section{THE RED COW}

of a little pig, roasting size, but I think the secret is that Sheppy feels ashamed to snap at so little a creature. But some day she will get a terrible surprise. If she comes around when Sheppy is having his dinner and tries to help herself there will be immediate trouble. That is where friendship ceases with Sheppy. I have known him to kill a pet kitten in about two seconds because it tried to help itself from his dish. Clementine will be sure to try it if she is around when he is being fed and then there will be doings. She will be even more surprised than she was in the stable last night. When we were milking Clementine strayed in, grunting pleasantly, to see what she could find. The kittens had also come for their evening portion of fresh milk. Presently Clementine, like her namesake in the song.

\section{"Stubbed her toe upon a kitten, Drefful sorry, Clementine!"}

The kitten let out a yeowl when the pig stepped on it that would have done credit to a full-grown cat. Its mother, Lady Jane Grey, rushed to the rescue and raked Clementine from shoulder to hip with distended claws. "Whee! Whee!" said Clementine as she shot through the door. She may think herself 


\section{CLEMENTINE}

capable of bossing dogs, but she has no illusions about cats.

While sitting in the hammock after dinner I had a chance to observe Clementine closely as she nosed around to see if any pears had fallen lately. While looking at her I was haunted by a sense of something familiar. Where had I seen that smile before? You know that the pig is the one thing in nature that has the "smile that won't come off." The corners of its mouth are permanently turned up so that it can hardly stop smiling even when it is squealing for swill. And when it is contented it seems to be smiling from the corners of its mouth to the jaunty little curl in its tail. While watching Clementine I realised that I had seen that smile before somewhere. After cudgelling my memory for a while I suddenly remembered. Her smile is exactly like that of the get-rich-quick promoter, the newly appointed office-holder, and other men who have been selfishly successful. As I realised this I called up pictures of scores of men with smoothly-shaven jowls and the pink cheeks of eupeptic high feeding and all of them had the same smile as Clementine. - From dealings I have had with them I know that they also have 


\section{THE RED COW}

much of her nature. It may seem to serious-minded people that I might be better employed than in studying the smile of a pet pig, but I do not think so. In future I shall be on my guard against sleek citizens who habitually wear Clementine's smile. You know I have been misled in the past by Shakespeare's lines:

"Let me have about me men that are fat, Sleek headed men and such as sleep o' nights."

I had an idea that fat men are usually goodnatured and honest, and that that was why Cæsar wanted them in his Cabinet. But when $I$ recall the actors who played with Booth $I$ remember that most of the conspirators who killed Cæsar were fat. Moreover, I remember that in his recent book on dieting Vance Thompson asserts that most of the men guilty of the crimes of high finance are fat men. Though he didn't say so, I am willing to bet a cookie that they all had a smile like Clementine's. Come to think of it, there are a distressing lot of fat men with that kind of smile to be seen around the hotel lobbies in our big cities just now, but $I$ have made a careful study of the pet pig and shall be on my guard. 


\section{XXVIII.-Feeding Pigs}

YONSARN a pig anyhow. I know how important pigs are just now, and we are making arrangements to raise our share of them, but that doesn't make me like them a bit better. Until this year we have contented ourselves with raising an occasional pig for our own use, but when preparing for this year's meat supply I felt expansive and bought a couple of plump little pigs. I admit that I like little pigs-both alive and roasted. Their perpetual smile, which even a session in the oven can't take off, appeals to me. But a full-grown, able-bodied pig is another matter - especially at feeding time. The two that we have finishing for winter pork have long since passed from the innocent, engaging sucking pig stage and have developed all the disagreeable mannerisms of the full-grown hog. To make matters worse, our arrangements for keeping hogs are of the old-fashioned kind that bring out all the bad qualities of the pig. When making necessary changes about the 


\section{THE RED COW}

barn the old pig-pen was torn down and this year's pen is a makeshift of the kind that you find among backward farmers-a small pen for them to sleep in and a larger pen built of rails, where they get their feed and take the air. The trough is a light affair made of a couple of boards, and they have no trouble in rooting it all over the pen, so that it has to be pulled around and turned right side up every time the brutes are fed. Things were not so bad until the pigs grew up, but now I dread feeding them more than any chore on the place. They can see me mixing the chop feed and the whole neighbourhood can hear the abuse they heap on me for being so slow. The remarks that they make in hog language about the Food Controller on this farm would not look well in print. When I start towards the pen with their rations my two fat friends are always standing up with their front feet hooked over the top rail of their pen and their mouths wide open and squalling. I have a club handy so that I can beat them back while I pull the trough into shape, but I have to drop it when I go to put the feed before them. This job is a regular fight. I have to hold the pail as high as I can and try to tilt a little of the feed into one end of the trough, in the hope of occupying 


\section{FEEDING PIGS}

them while I spread the rest evenly. I am lucky if I manage the trick without spilling the feed, and the racket is deafening. By the time I am done I am "all het up" and feel like taking the club and giving them a good mauling. I know I am to blame myself for having things in such shape, but that doesn't make me like the pigs a bit more. However, the trouble will be over in about a week, and we shall have a new pen and a proper trough for the next batch of pigs that we are arranging to raise for the good of the country. A man can fight a couple of pigs at meal times, but a whole litter would probably prove unmanageable. 


\section{XXIX.-Beatrice}

HE big sow that has been added to the farm live stock is making herself quite at home. She doesn't expect us to make company of her. She is willing to help herself and seems to feel hurt when we insist on superintending her helpings. The children have named her Beatrice, though I can't figure out just why. Beatrice suggests to me something slim and gracile rather than two hundred pounds of hump-backed and enterprising pork. They couldn't have picked up the name from anything they have heard me calling her since her arrival on the farm. I have called her many names, but I am quite certain that none of them sounded anything like Beatrice. It must have been an inspiration on their part, and we shall see how it works out. As Beatrice is not being fed up for pork but just being given a ration calculated to keep her in good health, she has a wide margin of unappeased appetite. Whenever she hears any one stirring she 


\section{BEATRICE}

is up and about at once, and to cross the barnyard with a pail of anything is quite a feat. Occasionally I take a pail of swill to the granary to add a few handfuls of chop-feed before giving it to Beatrice and $I$ find the experience rather exciting. She makes a squealing rush at me as soon as I open the gate and tries to get her nose into the pail. I kick her out of my way and then cross the yard to the granary door, kicking back like a horse at every few steps. I have heard at different times about educated pigs, but I seriously doubt if any trainer has been able to teach a pig table manners. You can teach a dog or a cat or a horse to beg for a dainty morsel, but I don't believe any one could teach a pig to wait when food is in sight. Beatrice wants what she wants when she wants it, and she doesn't care who hears her asking for it.

When Beatrice arrived she was put in the pen in which we kept the two pigs that we fattened for home-cured pickled pork and bacon, but it didn't seem to give her a chance for sufficient exercise, so we decided to shift around the pigpen so that it would give her an entrance to the barnyard. Since that has been done there has been nothing but 


\section{THE RED COW}

trouble. Not a door or gate can be left open for a moment, or the marauding Beatrice will be in mischief. As a matter of fact, she no sooner got access to the barnyard than she deserted the pigpen altogether. Although her sleeping room was filled with nice clean straw, she woudn't look at it. Instead, she began to root around the strawstack and to gather a big pile of loose straw on the south side. She chose the side that was sheltered from the prevailing northwest wind, and constructed a nest that is entirely to her own taste. When she gives up hope of getting any more food each day she burrows her way into her pile of straw and tucks it around her like a blanket. When I go to the barnyard after night I can hear her grunting rhythmically under about four feet of straw.

As long as I do not bang a pail or make a noise like something eatable she remains at rest, but if anything happens that conveys to her the idea that something to eat is about, there is an instant earthquake in the pile of straw, and Beatrice emerges with open mouth and complaining lungs Then the business of kicking and name-calling is resumed. We are hopeful that Beatrice will do her part in 


\section{BEATRICE}

the urgent business of meeting the pork shortage, and for that reason are willing to put up with her bad manners, but we do not expect to learn to love her very much. 


\section{$\boldsymbol{X X X}$.-Pig Frightfulness}

B

EATRICE continues to make her presence felt on the farm. A few days ago a boy whose mind was not synchronising properly with his body was doing chores. While his body was getting oats for the horses his mind was tilting with Wilfrid of Ivanhoe or "running a course with grinded lances" with Richard the Lionheart, or the knight of the Couchant Leopard. As he was away back in the Dark Ages his mind could not be expected to make his body attend to such trivial things as shutting granary doors in the last days of 1917. He left the granary door open. Beatrice saw her opportunity and heaved up her bulk among the bags and the bins. Shortly afterwards another boy of a tidy nature happened to be passing the granary. As his mind was right up to the needs of the minute he shut the door-without looking inside. Presently word was brought to me that Beatrice was lost. I ordered a search on the sideroad 


\section{PIG FRIGHTFULNESS}

and concession line, but not a trace of her could be found. It was fully four hours later that some one went to the granary and she was discovered. The granary looked like the scene of a Hun raid. Beatrice's frightfulness was astounding. She had torn open bags of beans, shorts, bran, chop-feed and cotton-seed meal. Apparently she had sampled everything in the granary and was so full that she couldn't grunt. When kicked out she gave a little protesting squeal, but she had an extra curl in her tail that showed how happy she was. She was so full that we were afraid to give her the usual ration of swill for fear she would swell up and burst. But there have been no evil effects, and when I go to the barnyard she gets under my feet and grunts with friendly impudence. But it is likely to be some time before she finds an open door again. We have had our lesson. 


\section{XXXI.-A Pig Bath}

$\mathrm{B}$

EATRICE, like myself, was inclined to rush the season. She seemed to think as I did that spring, or even summer, was back. On the perfect day I have been talking about she hunted up a sunlit puddle and indulged in the first wallow of the season. I am afraid it must have been a rather cold bath, for there is still ice in the bottom of all the puddles around the barnyard. But Beatrice must have felt the heat, for she made a thorough job of her mud-bath. When she got through she was just about as piggy a pig as you would want to see. She was plastered with black mud from head to foot, and the tone of her grunting expressed about the top note of contentment. She wandered into the field where the ploughing had commenced and began to root in a hopeful spirit. As her nose has never been restrained with a ring she was able to throw her whole vigour into the work, but I imagine that it was merely a spring rite rather than a food conserving effort. She might 


\section{A PIG BATH}

be able to find a reddock root that would be good for her blood, but I doubt if there was anything else available. She didn't stick to the job long, probably coming to the conclusion that it is more profitable to stick around the granary door. A while later I saw her sunning herself on the south side of the strawstack, where the mud could dry on her sides. Now that she has had her bath she looks surprisingly fresh and clean. The mud must have scaled off as soon as it was dry, and when it crumbled away it took with it all the winter's accumulations. She may have done some rubbing against the gate post or other convenient object, but I did not see her at it. Anyway her mud bath has left her whiter than she has been all winter, with a tinge of pink showing that suggests a proper tubbing. The spring seems to have an improving effect on her temper. Of course she is always hungry, but she is not so clamorous about it. 


\section{XXXII.-In Extenuation}

T ETTERS that reach me these days usually conclude with a word of solicitude for Beatrice. Tender-hearted people appear to be shocked by my references to kicking her out of the way when passing through the barnyard. I really wish they would tell me what to do when she comes over the top at me when I am carrying a pail of swill to which the chop-feed has not been added. It is entirely useless to try to explain to her that if she will wait a minute she will get a much better dinner. She wants it right away or sooner, and my kicks simply make her say, "Whoof! whoof!" As soon as I lower my guard she rushes to the attack again, and it takes skilful work to get into the granary with the pail of swill without having it spilled. At present the net result of our combats is that I have a stubbed toe. I haven't managed to make any impression on her, mentally or physically. One correspondent urges that I am doing injury to the "keep-a-pig" campaign by ex- 
patiating on her undesirable qualities. I don't think it is quite so bad as that. I merely show that pigs should be interned. No one has a deeper appreciation of a pig as a public duty or as a possible source of profit, but I don't think I need be blamed if I wish she had better table manners. I think the littlest boy hit the nail on the head when he confided to me: "I guess folks call pigs pigs because they are so piggish." As we have never gone in for hograising he had learned the meaning of piggishness before he learned anything about pigs. Consequently he thought the name very appropriate. Although Beatrice raises a "pathetic plaint and wailing cry" whenever there is food in evidence that she can't get at, she is still a highly esteemed member of the live stock. The trouble is that I have not learned enough about Froebelism to be able to "punish her in love." 


\section{XXXIII.-Beatrice Announces}

TT TOOF! woof! woof!"

Translated and properly censored, this means that Beatrice presents her compliments to the Food Board and announces the arrival of nine hungry little bacon producers.

\section{"Woof! woof! woof !"}

She also announces that she is food controller for her family and doesn't care a "woof" for regulations that are made at Ottawa. She recognises only the law of supply and demand, and if she doesn't get her full rations of swill, bran and similar necessities she is not afraid to express her opinions of everything and everybody, including the censorship. She now has to do the eating for ten, and the job is one for which she is fitted by both personal inclinations and hereditary instincts.

"Woof! woof! woof!"

She furthermore announces that she is ready to bite the head off any one who lays a finger on any member of her family. She stands ready to fight for 


\section{BEATRICE ANNOUNCES}

them instead of expecting them to fight for her. Good for Beatrice!

"Woof! woof! woof!"

In spite of her high state of belligerency, Beatrice is evidently very proud of her interesting family. Others may be able to boast larger families, but none can boast a plumper or lustier brood. (Nine seems to be the right and mystic number with swine. Hasn't Shakespeare something about a sow and "her nine farrow"?) They were ready to fight for their rights and squeal their protests for fair play before they were an hour old. Every one who has approached the pen to have a peep at them acknowledges that they are little beauties. They have the irresistible charm of youth-which can make even the young of a rattlesnake interesting if not lovable. Beatrice has every reason to be proud of them, though there doesn't seem to be any reason for being so gruff about it. A couple of weeks ago The Globe accused me editorially of being lacking in love for Beatrice. I admit the charge, but claim that this is a merciful provision of nature. Pigs are only lovable when they are small and plump and roly-poly. Our love for them does not endure. 


\section{THE RED COW}

"At length the pig perceives it die away And fade into the light of common day."

If it were not so we would not have the heart to slaughter our pigs and turn them into necessary bacon. By the time they are full-grown they have developed their piggish instincts to such an intolerable degree that we are glad to be rid of them. Instead of berating me for being lacking in affection, the editor should have drawn a lesson from the fact that when the time comes to turn our hogs into bacon we are mercifully enabled to do it without any wrench to our finer feelings. I protest that at the present time I view the little pigs with tenderness and affection, but when they are finally fattened I shall have no compunctions about loading them into a car and shipping them to Toronto-the place where every good Ontario pig goes when he dies. 


\section{$\boldsymbol{X} \boldsymbol{X} \boldsymbol{X I V} .-$ Receiving}

B

EATRICE is having so many visitors that we are thinking of having a guest book and requesting all callers to register. Certainly her family is worth looking at, and up to the present there have been no casualties. The whole nine are feeding and frisking and laying on fat. It is really amazing how fast they are growing. They are not only plumper, but more certain on their feet. Most of them can now stand on three legs and scratch an ear with a hind foot without losing their balance. And fight!-I am really ashamed of them. If a couple of the little rascals meet when wandering around the pen they promptly rush at each other with open mouths. Of course they are not able to do any damage, and they may really be playing, but their actions look bloodthirsty and they manage to raise weals and welts on each other's skins with their little teeth. All of them have red marks along their sides, faintly visible, that 


\section{THE RED COW}

were caused by embryo tusks in these little battles that are probably due to an instinct inherited from fierce old tuskers of the jungle. When not fighting, most of their waking hours are spent in efforts to root, though their big, floppy ears seem to overbalance them and they fall on their noses when they try to put steam in their work. But most of their time is devoted to sleep, which also has its activities. They huddle together side by side and on top of one another, and look like a pile of plump sausages. Every few seconds one of them gives a convulsive little jump as if suffering from nightmare, and the pile is never still. While watching them yesterday I had a chance to verify an observation made by a friend. He told me that in cold weather the little fellows at the end of the pile get chilled and at once get up and root their way into the middle of the pile, where they will be warm. At present the air is mild and they were not troubled much in that way, but once when a draft from an open door struck them the fellow on the outside felt a chill along his spine. He promptly got up and pushed his way into the centre by lying on top of the others and gradually wriggling down. Presently the one that was left exposed felt a similar chill and followed the 


\section{RECEIVING}

example of the first. One after another went through the performance, and while I was watching them the sleeping pile moved across the pen, as the changes were all being made from one end. If it were really cold, so that the fellows on both ends would be getting chilled and constantly pushing into the centre, their sleeping hours would be almost as active as the waking hours. Beatrice has quieted down since the first day and does not seem so much alarmed when any one approaches. In fact, if one of the family is picked up and makes a protesting squeal she merely grunts inquiringly. She is very proud of her family, and already it is evident that she has her favourites. One little fellow with a cowlick on his back gets Benjamin's portion at feeding time, and whenever he comes poking around her head she seems to caress him with her nose instead of rooting him out of the way. But in a few weeks she will bite their heads off if they come around her when she is feeding. As soon as they are able to root for themselves her affection for them will disappear.

With half a squeal and half a howl At mealtimes Beatrice starts to prowl; Her family following close at her heelsNine little pigs with nine little squeals. 


\section{$X X X V .-F e e d i n g$ Time}

$\mathrm{P}^{1}$ IG feeding is now the noisiest function on the farm. The little pigs are taking their share of skim milk and chop feed from the trough, and when their complaining falsetto is added to the guttural roar of their mother there is an intolerable racket on the place. Being every bit as greedy as she is, they pile into the trough so that it is almost impossible to get the feed before them. As Beatrice is always consumed by an ambition to get her nose into the pail while the food is being poured the work of feeding is accompanied by much kicking and language. As this interesting family has the run of the barnyard its members have considerable scope for enjoyment. The recent rains have made possible a number of satisfactory wallows, and the little pigs get as thoroughly plastered as their mother. I am not sure whether their carefree condition excites envy, but I do know that they are not obliged to have their ears washed and they can go to bed without having their feet scrubbed- 


\section{FEEDING TIME}

priceless privileges. Although it would be better if they had a bit of pasture to run in, they are not entirely deprived of green food. At noon every day they are allowed a run in the orchard with a boy to watch them and keep them out of mischief. (N.B.I must cheer up the boy who has the job by telling him the history of the royal family of Serbia, which is descended from a swineherd. Also I must encourage him to read Ivanhoe and get acquainted with Gurth, the swineherd.)

Of course it is a nuisance to have Beatrice and her family at large in the barnyard, but the world must have bacon, even if we are not properly equipped for hog-raising. All gates and doors must be kept closed at all times or there is sure to be trouble. Still, her alert presence disciplines us to tidiness and occasionally develops a bit of comedy. Yesterday morning I arrived at the barnyard just in time to witness an exciting little scene. The boy who looks after the hens had neglected to take a pail with him when he went to the granary for chicken feed, and thought he could carry it safely in a straw hat. With his hatful of oats he turned to close the latch on the granary door, and Beatrice saw her 


\section{THE RED COW}

chance. With a quick rush she grabbed the hat by the crown. The boy turned with a yell, but he was too late. For a couple of seconds there was a tugof-war-pull boy, pull pig, and then the hat tore apart. The boy had the brim and Beatrice had the crown with its load of oats. Holding her head aloft, as pigs do when trying to escape with some tidbit, she held up the crown of the hat and rushed into her pen. She didn't spill a grain and had a good feed all to herself in a dark corner. The boy's first impulse was to cry, but when he saw me he began to scold about having Beatrice loose in the barnyard. The joke was spoiled for me later in the day when I found that it was my cow-breakfast hat that had provided the sow breakfast. The boy had worn it by mistake. 


\section{XXXVI.-Beatrice Belligerent}

\section{T ESTERDAY I received from a correspond-}

ent a little jingle that deserves wide publicity at a time when every one is interested in pigs.

"A little pig with a curly tail As soft as satin and pinky pale Is a very different thing by far

From the lumps of iniquity the big pigs are."

That expresses the situation to a $\mathbf{T}$. The nine little pigs on the place are playful, winsome and amusing, but their able mother, Beatrice, is a loathsome creature. Among other depredations she put the finishing touch on our lane. This lane is of evil repute among auto drivers who visit us, on account of the twists and bumps in it. Well, Beatrice selected a spot where a defective drain had left the ground soft and trenched it with a luxurious wallow. Several visitors did not dare to take a chance on her bathing beach when approaching the house, so left their autos in the lane and came 


\section{THE RED COW}

afoot. Beatrice has also made a couple of sudden raids on the border of flowers beside the lawn, and managed to get a few bulbs-whereat much lamentation. Really, it will be a relief when she finally goes into retirement in a pen to prepare her for doing her bit on some Allied breakfast table. But her family is still at the lovable stage. 
HORSES 


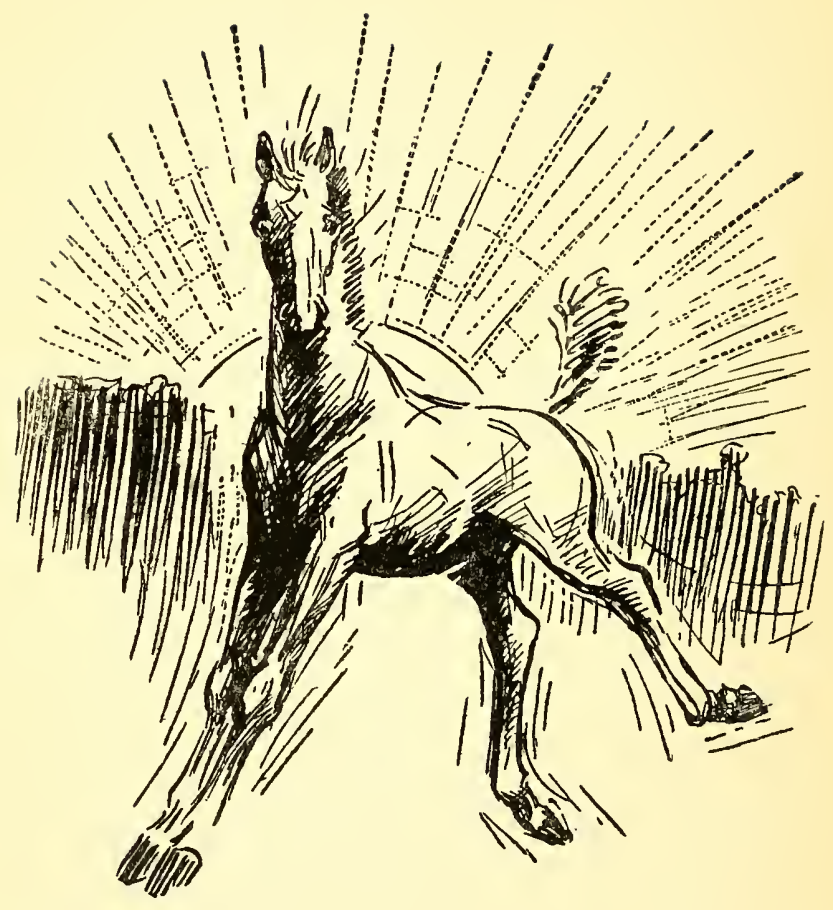




\section{XXXVII.-Dolly's Day Off}

T WONDER if any scientist has figured out the exact properties of blue grass. I don't remember seeing anything on the subject, but I am going to look it up, for blue grass hay seems to have food qualities that are not suspected by ordinary farmers. Besides being hay it must have the protein content, fat, starch and all other things that are to be found in a ration of alfalfa, rolled oats, oilcake and condition powders. It seems to be as potent as that brand of old English ale of which it was said that a quart contained "meat, drink and a night's lodging." Anyway, our dowager driver has had nothing but blue grass to eat all winter, and instead of developing "that tired feeling" as spring approaches she is so full of "pep" that she is teaching mischief to her own colts. Of course, she hasn't had much to do this winter, having convinced us that trotting was too great a strain on her constitution, and that even walking must be 


\section{THE RED COW}

indulged in cautiously and slowly. In short, she had managed by her conduct in the harness to have all the driving done by the other horse, which is a willing if rough-gaited traveller. As we couldn't spend a whole day on the road when it became necessary to go to the village we stopped trying to use the old malingerer. And it is not that she is so old, for she isn't. But whenever the harness was put on her back she seemed to develop sleeping sickness or some other obscure ailment, so we gave up using her except for farm work. But blue grass will out, and now we have fathomed her deep duplicity. She has simply been imposing on our good nature and there are strenuous days ahead for her.

A couple of days ago she and her colts were turned out for a run while the chores were being attended to. They seemed to enjoy their freedom and galloped around the field until they appeared to be tired. By the time the chores were done they were all standing at the barnyard gate, waiting to be let through, and I suspected nothing. When I opened the gate I reached for Dolly's halter, but she wheeled in her tracks and let fly at me with both heels. At the same instant the two-year-old crowded up and I 


\section{DOLLY'S DAY OFF}

caught him instead. I led him to the stable door and started him in and then turned to head off his mother, who had started towards the lane. Instantly she squealed and started towards the road with the yearling at her heels. The two-year-old heard her and popped out of the stable.

A moment later the three of them were off towards the road, where the gate had been left open on account of the snowdrifts. Not suspecting anything more than an ordinary frolic, I stood by the stable and whistled for them and called, "Cob Dolly" in my most seductive tones. But it was useless. When they reached the road they rushed north until checked by the drifts. Then they stopped, wheeled round and rushed south, passing the gate as if they had no interest in it. Before reaching the corner they slowed up. I whistled coaxingly and they stopped to look back. At this critical point a man with a horse and buggy turned the corner and started south. At once the three truants started after him, Dolly in the lead, with her tail in the air. I watched until they were almost a mile away, and then harnessed the other horse, conscripted a boy into active service and started in pursuit of the runaways. By the time we reached the road they were 


\section{THE RED COW}

nowhere in sight, having turned a corner about a mile away. The chase was now on in earnest.

When we reached the corner we saw the frisky trio nosing along the road and moving slowly to the east. Approaching cautiously as near as we dared the boy started on a wide circuit through a wheat field so as to get ahead of them. To any casual observer it would appear that he was cutting across the field towards the village to the north, but Dolly is no mean tactician herself, and she was not to be fooled. Before he had time to swing towards the road she snorted defiance and galloped away, with the colts at her heels. The boy came back to the road, climbed into the buggy, and we started a stern chase. Presently the three turned in at an open gate, and hope revived. If I could only get past that gate we could head them off. But the farmer whose property they had invaded thought he would help by "sicking" the dog on them. I drove wildly, but it was no use. They beat me to the gate and raced along the road ahead of me.

At this point I released about seven thousand calories of language, but it didn't help any. It merely raised my personal temperature to about one hundred and four. With tails up they galloped along 


\section{DOLLY'S DAY OFF}

until they came to a little road-that cut across a gore that had been left by the original surveyors of the township. I saw a chance, and sent the boy across the fields to head them off. As the little road had rail fences on both sides it was choked with snowdrifts, so it looked as if this manœuvre would work. They stopped, and the boy climbed over the fence ahead of them. In the meantime I drove along until I had passed the little road and took up a strategic position where I could head them off and start them towards home as the boy drove them back. Alas for the vanity of human wishes! The mail carrier had let down the fence a few rods down the little road so as to avoid the drifts by crossing through a field. Dolly saw the opening and took advantage of it at once. Into the field they went.

I admit that it was a beautiful sight to see them cavort around that ploughed field. It reminded me of a passage in Mazeppa:

"They stop, they snort, they sniff the air,

Gallop a moment here and there,

Approach, retire, wheel round and round,

Then plunging back with sudden bound,

They snort, they foam, neigh, swerve aside!"

But I didn't meditate on the poetry. Instead, I 


\section{THE RED COW}

meditated fondly on a blacksnake whip we used to own when I was a boy. It had a weighted handle, and a long, snaky lash, and it was said that a man could draw blood with it. If I had that whip and had Dolly where I could get at her- But it was no use thinking what I would do. Dolly had seen the gap opening out of the far side of the field on to another road and she led the way to it in high fettle. I believe they would have been going yet had not a kind-hearted farmer who saw the approaching cavalcade stepped out on the road and headed them off. This enabled the boy to get ahead of them with the buggy whip. He started them towards home and I managed to get them past my corner. Then they went into a pasture field through an open gate they had missed on their outbound trip. Noticing that they were hemmed in by a sheet of slippery ice I took an ear of corn that we had brought along, and by cornering her and tempting her at the same time I managed to catch her. But I didn't give her that ear of corn, even though I know one should never fool a horse in that way. I was afraid she might take it as a reward for her exploit.

When I led her back to the buggy I found that $15 \%$ 


\section{DOLLY'S DAY OFF}

the rope we had taken along had been lost in the excitement, but I was too mad to say anything about it. For a dreary mile $I$ led the brute along the road, and when we reached the home corner I let her go and laid the buggy whip along her ribs. Really there is little satisfaction in the cheap, light buggy whips they make nowadays. I merely raised dust from her hide as if $I$ were beating a carpet, but $\mathbf{I}$ didn't feel that the cut I gave her had any sting to it. When we reached the lane gate she went right past it. She didn't intend to live with us any more. But another neighbour headed her off and we finally got her home. This morning I hitched her up to drive to the village. She started off slowly, picking her steps like a cat, but I began signalling to her with the buggy whip that I was looking for some of the speed she had shown the day before. Her hide is an excellent non-conductor, but $I$ finally made an impression. She eventually caught my meaning and made a record trip to the village-I mean a record for her. Now what I am wondering is what she would do if she were fed on oats as well as blue grass. Anyway, I am going to cure her of the sleeping sickness, even if $I$ have to invest in a blacksnake whip. 


\section{XXXVIII.-The Colt}

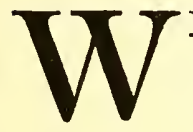

HEN I got home from the city I found that a great event had happened. A colt had arrived, and although it was almost eleven o'clock on a cloudy night, there was great disappointment because $I$ would not take a lantern and hunt through a fifteen-acre meadow to get a look at the little stranger. I was firm on the point, however, and denied myself the pleasure until the following morning. But we all went out to see the colt before breakfast, much to the distress of Dolly, who thought we had come to take him away and was ready to defend him with her life. She circled around him with her ears laid back, and when any one approached too near she unlimbered her heels for action. I foresee quite a job when she must be caught and put into harness again. Considering the matter from an artistic point of view, I fail to see why she should be so proud of her offspring. At present he seems to be all neck and legs -like the chickens they use to make boarding-house 


\section{THE COLT}

fricassees. His appearance reminded me of a remark I once heard: "We shall soon have a horse, for we already have the frame up." And besides being all legs, his legs are all joints. Still, "he has his mother's eyes," and I suppose that makes up for everything else. Real framers who have looked at him say that he is the makings of a fine horse, and they have seen lots of colts at his age that were more gangling and wobbly. Just now there is a fierce discussion raging as to what he shall be named, but there is a strong probability that he will be called "Brownie," though I am assured that in a few years he will be called "The Old Grey." 


\section{$\boldsymbol{X X X I X . - H o r s e ~ C o n t r a r i n e s s}$}

T $T$ is bad enough to have wells go $d r y$, but to have a horse complicate matters by refusing to drink good, pure water when it is offered to her and threaten to die of thirst unless given access to one particular pond, is an added exasperation. One of the horses used to be quite well satisfied with the somewhat inferior water in a tank at the barn, but when it went dry she became as nifty and pernickety as a connoisseur of rare wines. Although she goes to the village almost every day she declines absolutely to drink village water-even pure, cold rock water drawn from an artesian well. In the same way she sniffs superior at the water from the house well - the water that we use every day for drinking and cooking. It is not good enough for her. But there is a somewhat disreputable pond at the other side of the wood lot and as far from the stable as the farm will allow, and from this pond she is willing to drink until she almost bursts. When she gets busy with it you would think she was half camel and 


\section{HORSE CONTRARINESS}

trying to lay up a supply that would last at least four and a half days. The other horses are quite willing to take a refreshing drink from the Government drain when nothing else is handy, and this brought to light a strange peculiarity of the finicky one. She is willing to drink from the Government drain sometimes, but only from one particular spot in it. Lead her to any other part of the drain and she will stand over the water without tasting it, but let her get to her favourite spot and she will drink with relish even from a cow track. As the water in the drain is flowing steadily I cannot see how it can possibly taste better in one place than another. It is just a case of pure cussedness on the part of that tiresome horse. I have trouble enough doing the chores without catering to her whims. I am afraid that some day I shall get real peevish and let her go dry till she is willing to drink any decent water that is offered to her. I know there is a proverb which says that "You can lead a horse to water, but you can't make him drink," but I think if I set my mind to it I can make her drink. Anyway, I have no intention of leading her to her favourite pond twice a day when the weather gets below zero. 


\section{XL.-A Great Scheme}

T HAVE just discovered a new and effective way of gathering burrs, which I take pleasure in passing along to farmers who may happen to read this column. Along the Government drain at the end of the young orchard there was a luxuriant growth of burdocks this year. I never saw them without making up my mind to cut themsome other time. They throve lustily, and as I was always a week behind my work I never found time to cut them, so in due season they ripened and developed a crop of especially clinging burrs. Occasionally $\mathrm{I}$ gathered a few of these burrs when hunting for rabbits, and Sheppy gathered quite a few, but not enough to lessen the supply very materially. But one day last week the two horses and two colts got into the orchard because some one had carelessly left the gate open. They had been there some time before they were discovered-but their work was done. They had gathered every burr in the orchard. 


\section{A GREAT SCHEME}

Those that they did not get with their tails, manes and forelocks they got with their fetlocks. The youngest colt, having longer hair than the others, also managed to get quite a few on his sides. But between them they managed to make a complete job. I doubt if you could find a burr in the whole orchard, even if you made a careful search. When we got the brutes in the stable all we had to do was to pick the burrs off them and the job I had been intending to do all summer was done. At least it was in a fair way to being done. By much diligence we got the horses that must appear in public free from burrs, but the colts still carry some of their trophies. Still I think we should get the job finished soon if we have a few rainy days. Besides, the children can help on Saturdays. Real farmers may not approve entirely of this method of gathering the burrs on the farm, but I defy them to tell of any way in which the job can be done more thoroughly. A lively colt will gather more burrs in ten minutes than an industrious man can pick out of its mane and tail in a day. I offer this plan to farmers for what it is worth, and I wouldn't mind a bit if some of them called and helped me to pick the burrs from the colt's tail. $\mathrm{He}$ is inclined to kick. 



\section{TURKEYS}




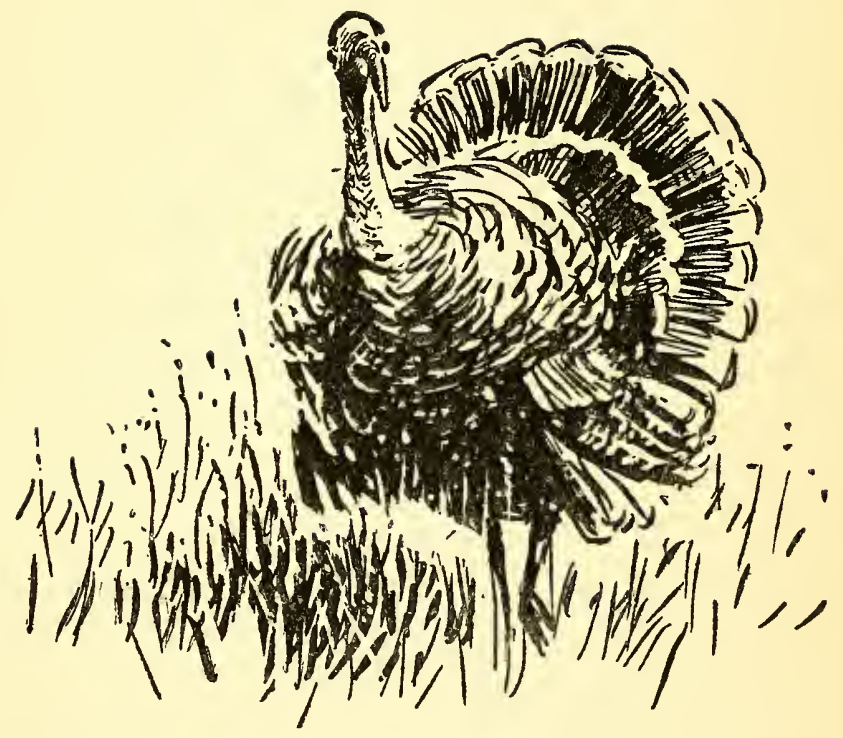




\section{XLI.-The Gobbler}

7 HERE are times when I wish that I had a proper scientific education. For instance, I would like to know just now whether turkey gobblers ever suffer from speaker's sore throat. None of the bulletins I have on hand throws any light on the matter. It would cheer me considerably to learn that gobblers occasionally suffer from aphonia or speechlessness. It sometimes seems to me that our bubblyjock is getting hoarse, though he is still able to gobble with vigour and authority. But unless he loses his voice before long I shall have to wring his neck-no easy job-or do without my usual amount of sleep. The trouble is all due to the fact that when the turkey hen tried to hide her nest she selected a bunch of long grass at the foot of a tree not far from the house. As she had been put off the cluck a couple of times to make her lay the proper amount of eggs it was decided to let her keep this nest. When she 


\section{THE RED COW}

finally got broody she was given seventeen eggs and allowed to settle down to the task of incubating Christmas dinners. As far as she was concerned this was all right, for she is a modest, quiet bird, whose presence would never be noticed. But this is not the case with her lordly spouse. Every morning at about a quarter to four he comes down from his perch on the ridge-pole of the stable and struts down to see if his lady has passed a comfortable night. As the grass is long and wet with dew he comes to the lawn and sends her his morning greetings, and I can tell you that a forty-pound gobbler can let out a very considerable amount of noise. He gets right under my window and explodes into assorted sounds. Once a minute, or oftener, he lets out a gobble, until I get up and throw a shoe or a hairbrush at him. Then I go back to bed and try to sleep until it is time to get up. If there is any way of treating his vocal cords so as to stop this morning charivari I wish some scientist would write and tell me about it. And, by the way, I can give him a little interesting information in return. After she was given her eggs the turkey hen evidently became dissatisfied with her nest and moved to a new location about four feet away. In order to do this she had to move her 


\section{THE GOBBLER}

eggs through the long grass, but she didn't leave one behind. How did she manage it?

* * * * *

There is an interesting fact about turkeys that $\mathbf{I}$ think I have referred to before, but as it has a political application at the present time $I$ am going to refer to it again. When the wilderness was conquered by the pioneers the turkeys were the only important wild creatures that were conquered with it. Apparently they believed in "peace at any price." While the timid deer fled to more remote districts, and the wolves "died in silence, biting hard," the turkeys allowed themselves to be deported to the farmyards, and proceeded to eat from the hands of their conquerors. But their spineless policy did them no good. Although they are fed and pampered they have lost their wild freedom and every year they are fattened for the tables of their masters. Those who believe in peace at any price would do well to meditate on this. The peace that is won at the price of submission is not worth having. Even though we may hate war and regard it as a criminal folly, the only way to end it and to secure a peace worth while is to fight heroically to put an end to war. Before dismissing this analogy it is worth 


\section{THE RED COW}

noting that the turkeys are not the only wild creatures that survived the conquest of the wilderness. The vermin, the skunks, and weasels also survived, but they are not respected. There is probably a moral attached to this also, for those who will take the trouble to study it out.

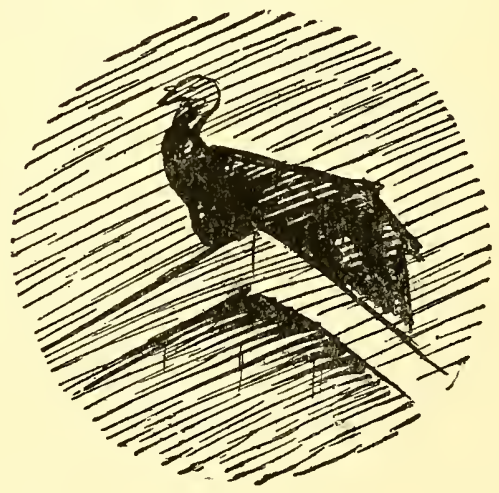




\section{XLII.-His Troubles}

L

AST night when we were milking there was a sudden racket on the roof of the cowstable that scared the cows so that they stopped giving down. You would think that a man with a wooden leg was having a fit on the shingles right over our heads. The pounding, flopping and scratching on the hollow roof made the stable resound like the big drum in an Orange parade. I couldn't imagine what on earth was happening, but it only took a step to get out doors and then the cause of the trouble was plain. The old turkey gobbler had decided to roost on the ridgeboard of the stable and he was having the time of his life getting up the roof. He was using his wings and his tail to balance himself as he clawed for a toe-hold, and he showed none of the stately gracefulness that marks his movements when he is strutting around the barnyard and proclaiming his overlordship. When he reached the ridge and caught his balance with a final flip-flap of his broad tail he 


\section{THE RED COW}

stretched his neck and looked around to see if any of the young gobblers were grinning at him. They were already quietly at roost with the mother hen at the far end of the roof, and the noisy approach of their lord and king made them huddle together in squeaking terror. Seeing that their attitude was respectful he settled down on his wishbone for the night. Being young and light they had flown gracefully to their chosen roost and doubtless could not understand what was ailing him when he sprawled around like that. I could sympathise with him better than they could, for when a man gets heavy and gets chalky deposits in his joints the climbing stunts he did as a boy become impossible. Time was when I could have walked up that roof as jauntily as if I were on parade on an asphalt sidewalk, but I suspect that if I tried it now I would make more noise than the old gobbler. 


\section{XLIII.-His Desertion}

TESTERDAY the old gobbler disappeared on a war expedition and did not return last night. This morning I must organise a rescue party and go after him. The party will be organised not to rescue him, but to rescue the neighbour on whom he has billeted himself. No one has any idea which direction he took, so we may have quite a hunt. But I am not afraid of losing him. An apoplectic gobbler of his size is easy to identify. But the old pirate should be at home, looking after his family, which is at present breaking through the shell. Last season he was a most devoted parent and looked after his family with unflagging care. He took them to the woods to get beechnuts and still kept one eye on the granary door, so that they could be on hand when the chickens were being fed. This year he will not have so large a flock to look after, but that does not excuse him for desertion and neglect. He must be rounded up, brought home and reminded of his du- 


\section{THE RED COW}

ties. Much of the time during the past month he stood, in a very dignified manner, near the nest where his mate has been brooding, so I am surprised that he should have deserted just when his family is breaking from the shell. But a thought strikes me. Perhaps the old rounder is away celebrating.

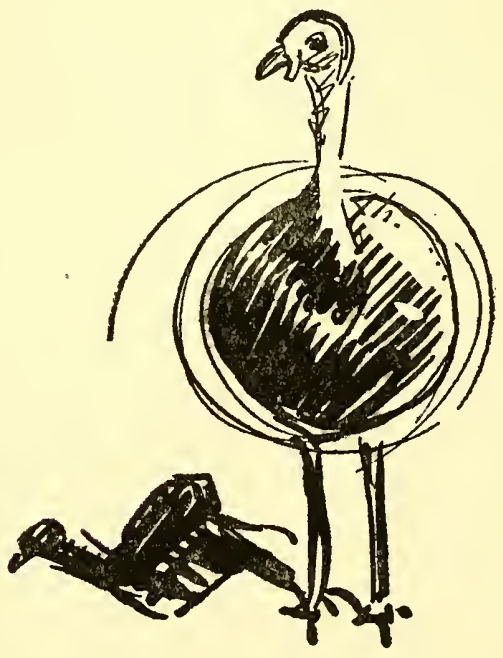




\section{XLIV.-His Belligerency}

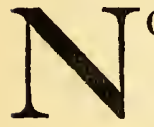

OW that his mate is hopefully hatching on a promising nestful of eggs, the old gobbler finds time hanging heavy on his hands and by way of diversion is proceeding to beat up all other gobblers in the neighbourhood. Whenever he hears another gobbler, no matter how faintly, he lets out a wrathful gobble and starts across the fields to trample on his rival. Neighbours have had to drive him home in order to save their flocks, for he is in the heavyweight class, and no ordinary country bird has any show with him. Of course, when we found out what he was up to we penned him in, but occasionally he makes his escape, and it takes quick work to keep him from crossing the fields and committing mayhem and tort and doing grievous bodily harm to well-meaning gobblers that venture to gobble their opinions about things. I wouldn't mind so much if he headed down the road on one of his foraging expeditions, for there is an ecru gobbler suffering from delusions of 


\section{THE RED COW}

grandeur that I have a grudge against. One day when I was driving to the village with the colt this earth-coloured gobbler seemed to rise out of the road in front of us, with a great spreading of tail, fluffing of feathers and rubbing of wings. His appearance was so startling that the colt shied, and in less than five seconds we were all piled in the ditch. The colt didn't get away and nothing was smashed, but things were pretty lively while the disturbance lasted. If I could only give our war-like bubblyjock the address of that particular gobbler, and he would go after him, I wouldn't mind his offensives.

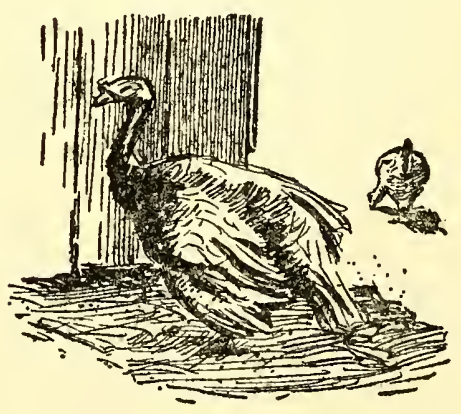




\section{$X L V .-H i s$ Cares}

WHE big gobbler is a changed bird these days. The cares of fatherhood are weighing heavily upon him. A few days ago he came across a Plymouth Rock hen that had hatched out a clutch of turkeys. Although they are barcly able to toddle around, the gobbler recognised them at once as part of his family and took up his duties as parent in a most commendable manner. With a subdued and responsible air he follows the old hen and the little poults wherever they go, stepping softly and refraining from noisy gobbling. But $I$ am afraid he is not entirely satisfied with the foster mother of his family. After the last big thunderstorm he came up to the door where I was sitting and was evidently very much put out about something. He was wet to his last feather and $I$ have seldom known him to be in such a bad humour. Possibly the old Plymouth Rock didn't act as a turkey mother should during a thunderstorm. Anyway, he seemed to hold me responsible for what- 


\section{THE RED COW}

ever went wrong, for he stood out on the lawn and swore at me for half an hour. When I began to get tired of the rumpus and was reaching for a copy of Hansard to throw at him Sheppy came around the corner of the house. The bubblyjock discreetly side-stepped behind the lilac bushes, for one thing that Sheppy can't endure is a hen, turkey or other fowl on the lawn. In spite of his complaints the gobbler is still looking after his duties as a father. A little while ago when the sun was hot I saw him standing beside his flock tail down, head pulled in like a turtle's and his wings spread out. He had converted himself into a sort of feathered pergola, under which his children might have taken shelter. But they paid no attention to him. Under the busy and clucking guidance of the old hen they were pursuing the elusive fly and other appetising insects. 


\section{XLVI.-His Prussianism}

I

DON'T see how the children failed to name the turkey gobbler. He is the most distinct character on the farm just now, but they have not given him a name. Perhaps they felt that they were not equal to the task. $\mathrm{He}$ is in a constant state of belligerency. As he is a super-turkey, weighing at least forty pounds, he is able to make quite a stir. Apparently he has laid to heart Nietzsche's advice and proposes to "Live dangerously." His mildest moments are threatening, and when he gobbles and rubs his wings on the ground he is an embodied offensive. This morning he renewed a trick that was a favourite with him last summer. At daybreak he began to air his grandeurs under my bedroom window and there was no more sleeping from that time. But as it is necessary to be up betimes in this spring weather I did not object. But if he keeps it up in the summer, when daybreak comes shortly after 3 o'clock, there will be trouble. 


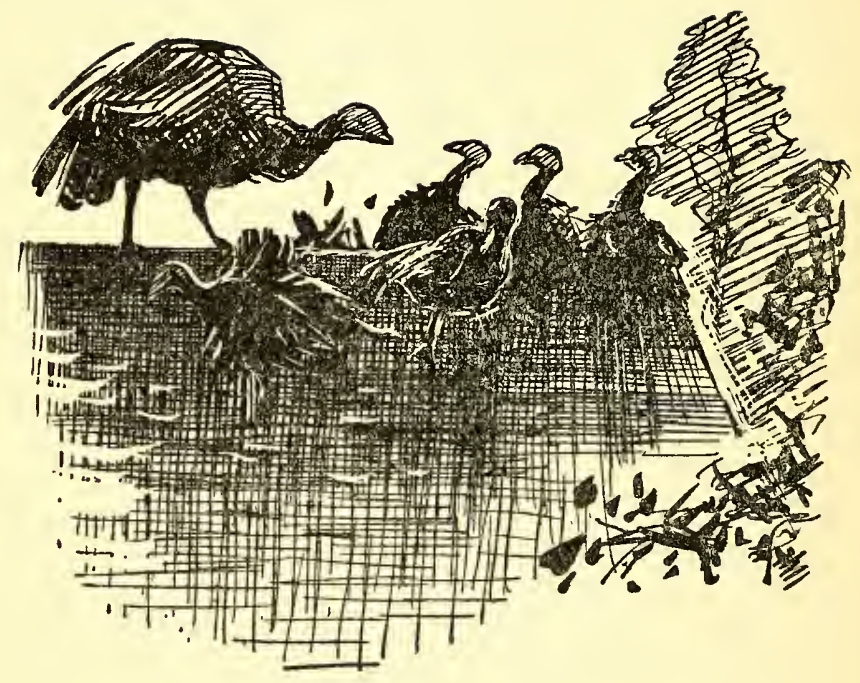


DOGS 


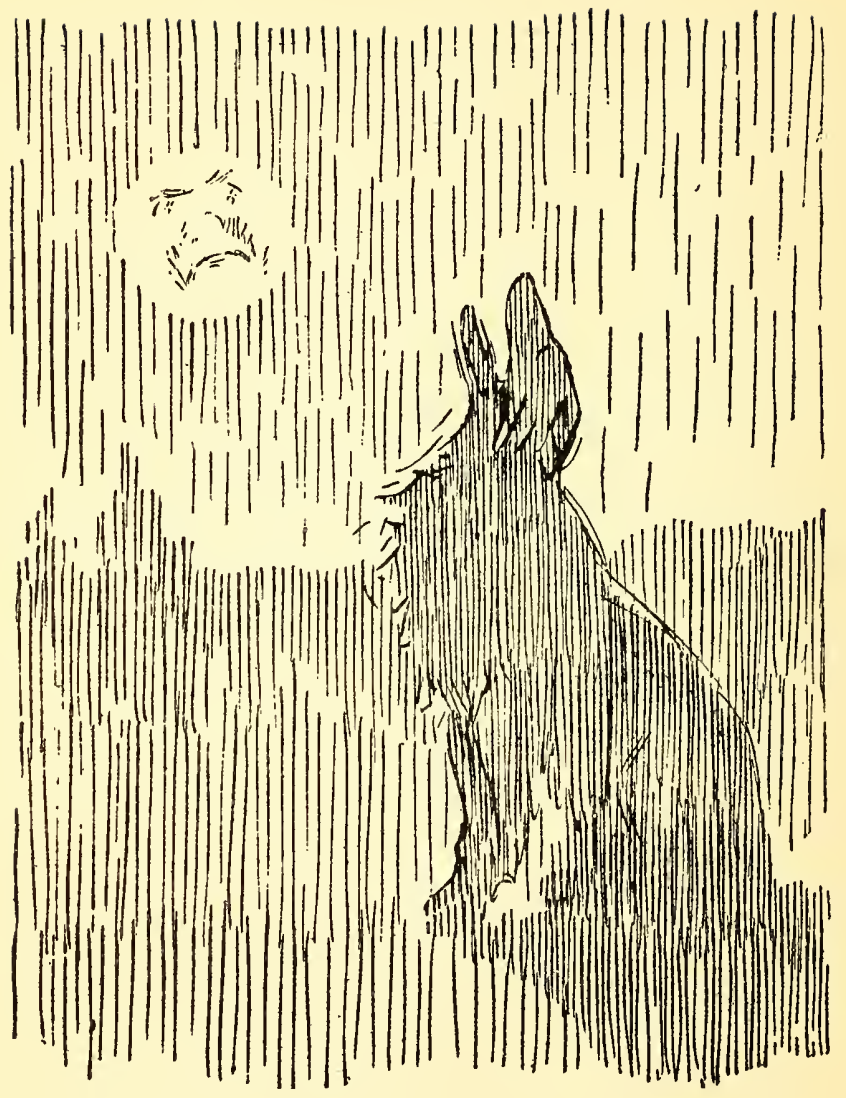




\section{XLVII.-A Moral Tale}

7 HE general slipperiness of things has been a great boon to Sheppy. Although I have seen him lose his footing several times, he gets along much better than the cows or the colts. As it is his daily chore to start the animals on their way to the Government drain to get their drink, he is now able to satisfy some old grudges. In ordinary weather he has to be very watchful for flying heels and prodding horns, but just now the animals have to concentrate their minds on keeping their feet under them, and are at a disadvantage when it comes to self-defence. Sheppy is now able to slip in on them and nip their heels, and they do not dare to take a chance on kicking at him. They find it hard enough to navigate with all four feet under them and their toe nails all in use, and an attempt to balance on two feet, or even three, would almost surely mean disaster. He was having such a high old time that I was thinking of scolding him away at watering time, but this morn- 


\section{THE RED COW}

ing something happened that gave me an excellent hint, and, besides, gives me a chance to moralise wisely. A few minutes before the cattle were turned out some one gave Sheppy a bone. It was a nice fresh bone that offered much palatable gnawing, and he was taking no chances on losing it. When he started to do his morning chore he carried the bone in his mouth, and the result was that he drove the animals without nipping them or making them wiggle too wildly over the ice. Ah, my friends, how often have I seen an ardent reformer, who was in the habit of herding the unregenerate, abate his passion for reform when he happened to get a nice juicy bone in his mouth! Yea, I have even known newspapers and political parties to be made much more temperate in their expressions of opinion by the timely contribution of a few bones. Here assuredly is a lesson for all of us.

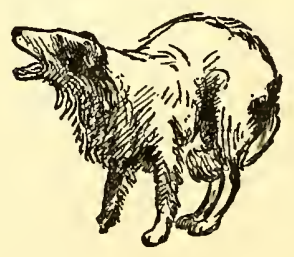




\section{XLVIII._Sheppy's First Coon Hunt}

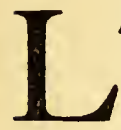

AST night Sheppy was initiated into the mysteries of coon-hunting. The opinion has prevailed in the neighbourhood for some time past that coons are becoming plentiful again. Their tracks have been seen along the government drains and around watering ponds where they probably went to hunt for frogs. Moreover, before the corn was cut ears were found partly stripped and gnawed, and the work was pronounced by experts who had been coon-hunters in the old days as the work of coons. The matter was brought to a head yesterday when I saw coon tracks on the sideroad while driving home from the village. It was unquestionable that there were coons in the neighbourhood, and a coon hunt was quite in order. Of course, we had no reason to believe that Sheppy would prove to be a good coon-dog, but he has a hasty way of dealing with woodchucks and muskrats that he manages to catch at a distance from their holes, and more than once he has tracked 


\section{THE RED COW}

rabbits though he has never managed to catch one. The only way to find out whether he had in him the makings of a coon-dog would be to try him. After discussing the matter with an eager boy it was decided that we would sneak away from the house after all the chores were done and give Sheppy a tryout. We would have to sneak in order to keep the younger children from begging to be taken along. Having laid our plans we managed to sneak away about half past eight, after giving a warning whisper in the right quarter that we might be away for a couple of hours. Sheppy seemed doubtful about the wisdom of taking a night ramble, but after some coaxing he decided to come along.

$$
\text { * } * * \text { * }
$$

We took the dog to our own corn-field first and were gratified to see how thoroughly he entered into the game. It was a dim night with the moon almost hidden by thin clouds, but there was enough light for us to see Sheppy racing over the cornfield in the most approved manner of the coon-dogs of a bygone age. He crossed and recrossed it thoroughly without finding even a mouse-if he had found one we should have known for he is a gifted mouser and often gets a mouse when crossing the pasture. When 


\section{SHEPPY'S FIRST COON HUN'T}

he had done the cornfield thoroughly we decided to put him through the wood-lot, and after starting him in with an encouraging "Hunt him up, sir," we sat on the bars in the fence and waited. We had not been waiting long before a sound of distress was heard. A cat was meowing piteously along the path over which we had just walked. There was no doubt about it. "Lady Jane Grey" had noticed us starting out and had decided to share in the fun. But she was evidently in distress and the boy started back to see what was the matter. He found her in the branches of a shade-tree in which she had evidently sought refuge from Sheppy, who would not recognise her so far away from home at night. After she had been rescued and "scatted" back to the house we sat on the bars and waited patiently for the dog. At last he returned to us panting as if he had run for miles. There was no doubt about it. He was working splendidly and would probably need only a little training to make him a first rate coon-dog. But he had not managed to locate anything on the home farm so we decided to visit a neighbour's corn-patch which backs against the largest wood-lot in the neighbourhood. The wood-lots on four farms happen to be on four corners where 


\section{THE RED COW}

the line fences cross, and the result is a wood-lot about four times as large as can be found on ordinary farms. Besides there are still some big elms left in this patch and if there would be coons anywhere it would be there. We started towards this happy hunting ground with Sheppy in the lead. We climbed over two wire fences in crossing the road and the second one was too tight for Sheppy. He could not get through so he ran along the road until he came to a rail fence and then he travelled parallel with us on the other side of another wire fence that would not let him through. We were sorry for this at first but afterwards we were glad. When we had travelled about twenty rods through the field towards the other wood-lot Sheppy suddenly began to show signs of excitement. $\mathrm{He}$ began to run round with his nose to the ground and was quite evidently following a trail of some kind. Presently he started away across the pasture field he was in and was lost to sight. A moment later there were a series of sharp snarling barks and the boy was filled with sudden alarm. He remembered that there were sheep in that field so I whistled for Sheppy. After a bit we saw him coming-he is largely marked with white-and his nose was to the ground. In fact he 


\section{SHEPPY'S FIRST COON HUNT}

seemed to be fairly ploughing it through the long grass. We debated for a moment whether he had been molesting the sheep and then things began to happen. The boy was nearer to the wire fence than I was and Sheppy tried to get as close to him as possible. Suddenly the boy yelled, "Wow! Whew!" and began to act as if he had taken an emetic. I had no time to solve the mystery before the wind blew on me and I understood. Sheppy had not been bothering the sheep. No indeed. Sheppy had been having an argument with a skunk and there was strong reason-very strong-to suppose that he got the worst of it. It was then that we were glad that there was a tight wire fence between us and Sheppy. After failing to get the sympathy he was looking for he proceeded to wipe his nose on the grass. Then he found a hole of water and wallowed in it. He evidently felt a wild need of a bath. I don't think I ever saw a dog so earnest about his toilet. When he got out of the water hole he wiped himself dry on the grass by lying on his side and pushing himself along with his feet. Then he rolled over and wiped the other side. Still he was not satisfied. He rubbed his nose with his paws for a while and then plunged into the water hole again. And all the time 


\section{THE RED COW}

we mingled wild laughter with words of mourning and wondered what on earth we would do. At last we decided that we might as well call off the hunt as he couldn't trail an automobile, much less a coon, after getting such a dose. So we started towards the road with Sheppy still on the other side of the fence. He kept abreast of us as we moved homeward,

$$
\begin{aligned}
& \text { "An amber scent of odorous perfume } \\
& \text { His harbinger." }
\end{aligned}
$$

When we reached the road Sheppy came along like a comet with a tail of odour streaming out behind him. He seemed to be trying to run away from it, but it was no use. If he could quote Milton he would no doubt have said:

"Which way I fly is hell; myself am hell."

After noisily repulsing his attempts to nuzzle against us for sympathy we sat on another set of bars and moodily reviewed the situation. It was far from probable that our home-coming would be the signal for rejoicing. Sheppy is the family pet and now his usefulness as a pet was seriously impaired. While we were talking this over Sheppy came and stood right under us. That ended the talk. We 


\section{SHEPPY'S FIRST COON HUNT}

went away from there. Finally, after many hesitations, we reached the house and through the kitchen window looked at a scene of domestic peace. The family was assembled around the table reading. The temptation was too great for the boy. Sheppy was standing at the door, and stepping forward the boy opened it and quietly let him in. For a few seconds there was no change in the peaceful scene. Then arose a wild cry of dismay. The family bulged out of the kitchen through both doors. It was a good thing that there were two doors or someone might have been trampled on. Every one wanted fresh air. In fact I never knew fresh air to be so much in favour as it was for a few minutes. Poor Sheppy came out again to see what all the excitement was about and seemed hurt that his best friends went back on him so unanimously. When peace was restored and the house aired, we were allowed to enter, though insinuations were cast out that we smelled about as bad as the dog. This was a libel, however. This morning Sheppy found himself so unpopular that he went out to the cornfield to catch mice when the shocks were overturned for husking. When he came home at noon he looked hurt and humiliated and stood about a rod away from me and looked as 


\section{THE RED COW}

if he thought I was to blame for all the trouble. I am not sure but he was right. Anyway he and I know that there is truth in the political maxim: "When you fight with a skunk it doesn't matter whether you win or lose; you are bound to stink after it." We are hoping that it will wear off before spring.

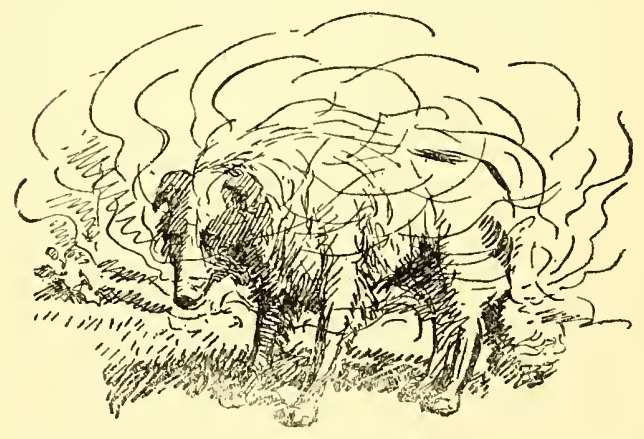




\section{XLIX.-A Rabbit Chase}

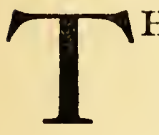

HIS morning after the chores were done I decided that I should take a look at the young orchard to see that mice and rabbits were not damaging the little trees. The sun was shining, and as most of the snow disappeared in the recent thaw it was the best day for a ramble that we have had since winter began. And I am glad that I went, for I not only enjoyed the fresh air but had a few minutes of excitement that started the blood coursing in my veins. Sheppy decided that he would like a ramble too, and thereby hangs a tale. While I was examining the trees he made little excursions about the field nosing for mice. While I was rejoicing that there were none for him to find and because there were no rabbit tracks I almost stepped on a little cotton-tail that had a form in a bunch of wild grass that was shaded by a big weed. The rabbit popped out, and at the same instant I yelled, "Sic him!" Sheppy was a few rods away, but when he saw the game he let out 


\section{THE RED COW}

one quick, yapping bark and gave chase. The rabbit had started towards a haystack at the other side of the field, but when the dog took after him he changed his mind and began to circle towards the south. He looked like a streak of brown fur, and about four rods behind him Sheppy looked like a streak of black and white. Both stretched themselves out until their bellies seemed to touch the ground, but my eye could not detect any change in the distance between them. Neither seemed to gain an inch. They kept it up for about thirty rods and then Sheppy stumbled over a corn stubble and lost a few feet. The race went on in absolute silence until they reached the wire fence at the road. The rabbit slipped through and Sheppy had to stop. He ran around and barked with rage as his quarry scooted up a neighbour's lane and disappeared among some piles of rails. I then had time to examine the cosy form where the rabbit had been resting. After noting how nicely it was lined with grass I ruthlessly kicked it to pieces, for rabbits are not to be encouraged in a young orchard. I could not find that he had done any damage, but I am not taking any chances, and this afternoon I am going to take the rifle and Sheppy and hunt through the orchard 


\section{A RABBIT CHASE}

carefully. After the race was over Sheppy was so much ashamed of his failure that he went back to the house without coming near me. When I got home he thrust his muzzle into my hand and wagged his tail and tried to make me understand that rabbits are not in his line. A slow-footed woodchuck suits him better. But I am going to train him to chase rabbits, even if he cannot catch them, for if he keeps them moving they may decide that they are not popular here and move away to some one else's orchard.

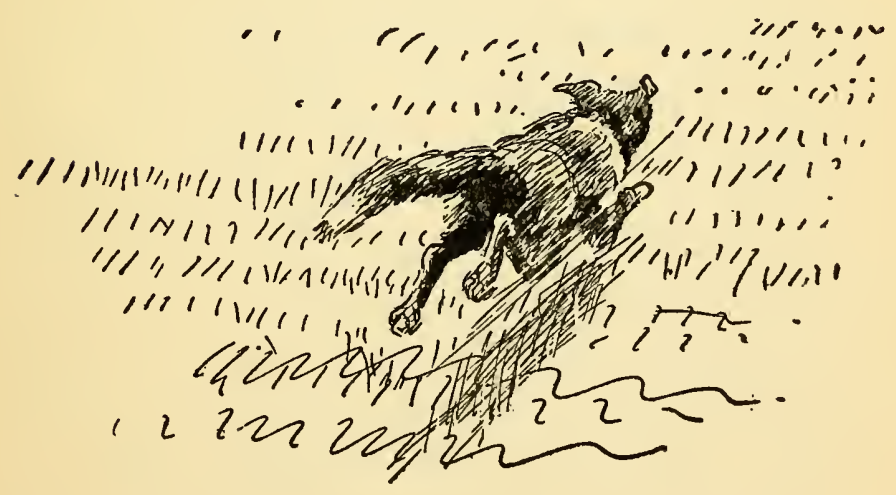




\section{L.-Fights and Feuds}

T DON'T know why it is, but every time there is something interesting going on, like a political meeting or a dog-fight, I am always away from home or $I$ have a previous engagement of some kind. Here is Sheppy having a whole series of fights to maintain the supremacy of the farm, the freedom of the concession line, and his place in the sun, and I haven't seen one of them. According to the uncensored and detailed reports I have received, the fights were well worth seeing, and Sheppy acquitted himself in a creditable manner. The trouble is all due to a couple of dogs belonging to a gang of ditchers working in the neighbourhood. These dogs-a big hound and a little terrier-have done so much coon-hunting in their day that they consider themselves at liberty to roam wherever they please. Several times they insolently crossed our fields and that is something that Sheppy will not stand for. Any dog that ventures on this farm has to put up a fight for the privilege. $\mathrm{Up}$ to date 


\section{FIGHTS AND FEUDS}

Sheppy has defended his dominions successfully, but in all previous battles he has had to deal with one dog at a time. But it seems that the present invaders have learned in many coon-fights that team play is best and their tactics have been surprising and somewhat discomfiting. Sheppy scorns to attack the terrier, which wouldn't make a decent mouthful for him, but when he grapples with the hound the terrier catches him by a hind leg or by the tail, and as I guess a little dog's bite hurts just as much as a big one's, Sheppy can't give his undivided attention to the hound. I am told that in the first scrap he kept whirling around distributing his bites impartially and managed to chase both the other dogs off the farm, but in later attacks they worried him some. When I came home he whimpered around me and showed me his scratched nose and tried his best to tell me about his troubles. He had done his best to protect the farm during my absence at the village, and it was quite evident from his manner that he thought he deserved some praise and petting. I sympathised with him entirely, but I half regret that the ditchers have moved on with their dogs. I shall not have a chance to see Sheppy in action with two dogs. But I never have any luck. 


\section{THE RED COW}

Sheppy has a standing feud with a neighbour's dog that is amusing rather than bloodthirsty. Though they have been barking at each other and threatening each other with much bad language for three or four years, I don't think they have come to grips yet. Whenever either of them starts barking at anything the other immediately flies into a rage and begins to make disparaging remarks in a loud tone of voice. Sometimes Sheppy goes half way across the field towards his enemy, barking defiance, but when his enemy finally gets mad and runs towards him he rushes back to the house to safety. In the same way the neighbour's dog sometimes comes half-way across the field, making insulting remarks, until Sheppy finally gets so mad that he starts after him. The neighbour dog then makes a strategic retreat. I don't think I have ever seen them nearer than ten rods to each other, and I don't think they have ever had a fight, but they keep up their quarrelling every day. I suspect that each has so impressed the other with his prowess that if they ever met accidentally they would both run for their lives. On moonlight nights they keep up such a rumpus that no one in the neighbourhood can get any sleep until both are taken indoors and ordered to be quiet. 
CATS

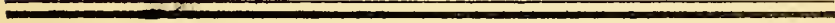





\section{LI.-A Page of High History}

7 HIS is the story of a "harmless, necessary cat." I think I told you some time ago that the children make it a practice to name their cats after prominent personages in history and public life. Lady Jane Grey is a gentle, domesticated cat of many admirable qualities and her name seems very appropriate. Her fur is grey, her table manners perfect, and in disposition she is kind and affectionate. The other cats have been named with equal judgment and discretion, but I dare not mention their names for fear that public men who have not been honoured might feel jealous. I had become quite accustomed to the high sounding names of the household pets, and had acquired the habit of inquiring every night at bedtime for the whereabouts of certain distinguished persons. Often and often when shutting up the house for the night $I$ have kicked out some of our most honoured names just as ruthlessly as if I were an office-hungry Opposition 


\section{THE RED COW}

returning to power. And now it is my privilege to record a great event. New Year's Day there was great news. The children learned with pride and delight that their favourite cat had been honoured with a title. Instantly there was wild excitement. The distinguished cat was called by his familiar name, and finally was found in a shed, where he was trying to think up some scheme for commandeering a quarter of beef that hung beyond his reach. $\mathrm{He}$ was hurried into the house for the ceremony of dubbing, and while the preparations were being made he purred as contentedly as if he knew just what was happening. I was really surprised to see how well the children understood what to do. While one held him in a respectful attitude in front of a Morris chair another got the carving knife and prepared to administer the accolade. There was only a moment's pause while they asked me to indicate the exact spot on his neck that should be smitten by the ennobling sword. Then they completed the ceremony with

"a ribband to stick in his coat."

As cats are by nature the most aristocratic of animals, this one took his new honours with the 198 


\section{A PAGE OF HIGH HISTORY}

air of one who was used to them, though he caused some criticism by switching his tail in an unknightly fashion. Seated high on a sofa cushion, he purred contentedly and received the homage of his loyal retainers. He closed his eyes, bristled up his whiskers and smiled like a Cheshire cat. Even Sir Jingo McBore could not have given him any pointers on noble and knightly conduct. I am afraid that if he receives much more homage of this kind he will become too haughty to associate with the other cats and will pose as "the cat that walks alone." Still his nature may not be changed entirely by his newfound honours. I noticed that once in a while he would stretch out a paw in a sleepy way and spread his claws as if he were dreaming of mice, for he has been a famous mouser. I hate to think that he may become a social butterfly on account of his title, but a stanza from Calverly haunts my memory. As nearly as I can remember it runs like this:

"In vain they set the cream jug out

And cull the choice sardine,

I fear he never more will be

The cat that he has been." 


\section{LII.-A Spring Orgy}

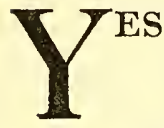

ESTERDAY the children called me to see

an amusing exhibition that breathes the spirit of spring. The house cat, fat and lazy, had found a little patch of catnip that had started showing signs of growth. He was biting at it as if he were going to eat grass like an ox. After he managed to get some fragments of leaves into his mouth and had swallowed them he lay down and began to roll over. He kicked his legs into the air, rolled around, wallowed and otherwise acted foolishly. The catnip seemed to fill him with a spring madness that induced all kinds of foolish excesses. Finally he jumped into the air with the playfulness of a kitten and rushed around the corner of the house, switching his tail and acting as if he had renewed his youth. By the way, I may as well record an observation about this cat while I am at it. He is inclined to be pampered in the matter of food, for he is always around begging when any one is eating, but in spite of this fact he 


\section{A SPRING ORGY}

is a famous mouser. Hardly a day passes that I do not see him coming out of the orchard with a mouse, and some days he gets two or three. I have heard it said that only well-fed cats are good mousers, and I think there may be something in it. They go mousing just as a well-fed sportsman goes hunting. 



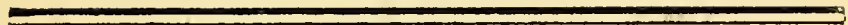

BIRDS 


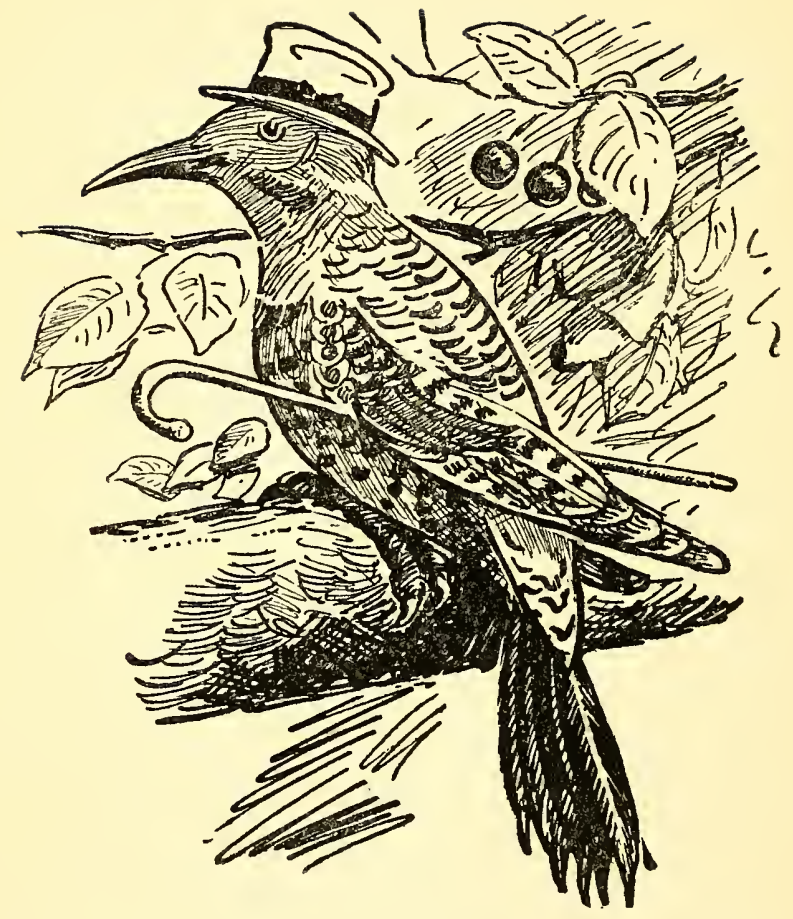




\section{LIII.-A Disgusted Blackbird}

I

KNOW it was a low-down thing to do, but I did it with the best of intentions-though I am afraid the blackbirds will never understand. They will probably think that after the good work they did in eating white grubs, cutworms and other pests while I was preparing the corn ground, I should have treated them differently. But it was just because they did so much good work that I treated them so badly. I was so grateful to them that I did not want to treat them in the usual way when the corn came up. In past years it was the custom to loaf around with a doublebarrelled shot-gun about the time the corn was coming through the ground, but this year the blackbirds were unusually plentiful, and as the season was late they probably had many broods of young to feed. Anyway they came to the corn field in flocks and followed the plough, disc and harrow, picking up every worm and bug that came in sight. They demonstrated the fact that they are true 


\section{THE RED COW}

friends of the farmer, even though they may have faults. So when it came time to plant the corn we gave the seed grain a good coating of tar, and then rolled it in ashes to dry it. This used to be a common practice many years ago, though I haven't seen any one doing it of late years. It certainly made the corn about as unappetising as anything possibly could, so I was not surprised, when I went to the corn field a few mornings after the planting, to find a blackbird sitting on the fence, coughing and spitting and using unparliamentary language. But I will take part of that back. Some of the language used by parliamentarians during the past few months has been of a kind that makes me wonder if any kind of language can possibly be unparliamentary. But to get back to the blackbird. He evidently thought I had played it low down on him after the way he had helped me in the matter of grubs, and I had no way of telling him that like a lot of human beings who do disagreeable things to one another I had done it "for his own good." A little tar and ashes in his beak was a greater kindness to him than a charge of bird shot.

$$
\text { **** }
$$

Now, I dare say there will be some scientific per206 


\section{A DISGUSTED BLACKBIRD}

sons who will sniff superior and say that my remarks about the blackbird coughing, spitting and cussing are only nonsensical romancing. That is the trouble with scientists. They observe things in nature in so matter-of-fact a way that they never get at the real truth. Moreover, I have long been convinced that only the observations we make about ourselves are of any use in trying to get at the feelings of others. For instance, I can remember a time when I would loaf along and observe a man digging in a ditch. Seeing him at so excellent and necessary a task $I$ would imagine that he was full of fine ideas about the nobility of labour and the great virtue of the work he was doing, and I might even try to write a song of ditching to express what he felt but was unable to voice. Lately I did some ditching, and I know that my earlier observations were all wrong. If a man came along wearing summer flannels and paused to observe me and tried to understand my emotions and thoughts while doing a very necessary piece of ditching, my thoughts would have run somewhat as follows: "I wonder what that pop-eyed rabbit means by standing there gaping at me. I wonder if I couldn't accidentally splash him with some of this mud." And all the 


\section{THE RED COW}

time I was doing a noble piece of work and knew it, but that was the way I felt about it. I am willing to bet a cookie that when I was doing my observing in comfort on the dry bank the thoughts of the man sloshing around in the ditch were much like those expressed above. And I am by no means inclined to confine this method of interpretation and observation to human beings. My dealings with birds and animals have convinced me that each of them has as distinct a character and personality as any human being. So when I try to imagine the emotions of a blackbird that has sampled a grain of tarred corn, that he has dug up with much labour, I merely try to imagine what I would do and say if some one whom I had helped with his work had put coal tar in my salad. I am afraid that having more capacity for spitting I would spit harder than the blackbird, and having command of a larger vocabulary I would use worse language and more of it. Making my observations in this way $I$ have no compunctions about explaining the state of mind of the blackbird as I did, and I defy any scientist in the lot to prove that $I$ am wrong. And the best of it all is that the blackbirds soon got wise and stopped trying to dig out my corn. 


\section{LIV.-A Visitor}

TESTERDAY morning a distinguished visitor spent a few minutes with me in the sugar bush. To be exact, I was aware of his presence for a few minutes. He may have been with me for quite a while, though I didn't notice him. When I got to the wood-lot I had only one idea, and that was to save sap. It had been running all night. Some buckets were overflowing and others brimming dangerously, and I had to hustle around with a pail before giving attention to anything else. When I put a stop to the waste I lit the fire under the pan and got the work of boiling in properly started. Then I had leisure to notice that the crows were making a racket. Glancing towards the centre of the disturbance, I was surprised to see a huge bird sitting in the top of the biggest maple, about fifteen rods from where I was working. My first thought was that it was a great horned owl, but it was altogether too large. Although the crows were noisy they did not approach 


\section{THE RED COW}

very near the object of their wrath, which seemed royally unconscious of their clamour. I walked towards the tree-the sole remnant of the original forest, a huge maple that is over three feet in diameter at the base, and which reaches fully thirty feet above the second-growth trees by which it is surrounded. When I was within about forty yards of the tree my visitor stretched his neck and turned to look at me. It was a magnificent bald eagle-the first I had ever seen outside of a zoological garden. I was near enough to catch the glint of his fierce eye. He gave me "the once-over" with an expression of haughty disdain, such as I have seen on the face of a bank President who has been forced to look at something that has spoiled his day. Then he turned toward the rising sun, leaned forward as if making obeisance, and launched himself into the morning with a wide beat of wings. He paid no attention to the pursuing crows. After a few powerful strokes he swung up on a vast spiral and sailed away to the east. Although he was so unsociable, I was glad to have seen him, and I had a really exciting story to tell the children when they got home from school in the evening. 


\section{LV.-A Farewell}

T FEEL safe in announcing that the great blue heron that spent the summer spearing for frogs and tonging for clams in the Government drain has finally gone south. By this time he is probably toning up his digestion on a diet of young alligators and electric eels while

\section{"Hid from view}

By the tall, liana'd, unsunned boughs O'erbrooding the dark bayou."

For a time it looked as if he intended staying with us all winter. The bird books say that the blue herons leave for the south about the middle of September, and I was ready to bid him good-bye about the time we were picking the apples, but he lingered on through October. When November came and he was still wading in the drain or flapping slowly across the fields, with Sheppy trying frantically to bite his trailing toes, I began to be afraid that something ailed him. But he flew strong at all times, and some other explanation must be found 


\section{THE RED COW}

for his lingering in the lap of winter. And he lingered in winter's lap all right. Every week in November he was seen quite as frequently as during the summer. Even the first flurries of snow did not drive him away. As the streams were still free from ice he probably found no difficulty in getting his living, and he put off the trip south as long as he dared. The last time I saw him was on the 5th of December, when he crossed over, flying high and headed due south. Something about him, as they say in novels, told me that this would be positively his last appearance for the season. There was a snowstorm in progress at the time, and it was freezing. Canada was no place for a bird that, according to the best scientific authorities, should have gone south almost three months ago. He has not been seen since that last flight, and as the streams are not only frozen over but drifted full of snow, it is not likely that we shall see him again. Sheppy now has to take his exercise by chasing sparrows. 
GENERAL 


\section{A BALLAD OF BUGS}

My Dooley potatoes have bugs on their tops, Hard ones and soft ones that eat day and night, There is something the matter with all of my cropsA bug or a worm or a pest or a blight. My orchard of apples, in which I delight, Is a codling moth heaven-my cherries have slugs$O$ pity the farmer who works with his mightChanting a ballad whose burden is bugs.

The tomato worm crawls, the grasshopper hops,

The aphid sucks juice, the rose chafers bite, The curculio stings till the little plum drops And the damage they do on the farm is a fright. In vain we seek help from the fellows who write Of "Production and Thrift"-intellectual mugsThe farmer must hustle and keep up the fightChanting a ballad whose burden is bugs.

The bug on the farm with his appetite stops,

When his "tummy" is filled he is ready for flight, But the Big Bugs who work in the law-making shops Are grabbing for all that is lving in sight. They have tariffs and tricks like good old "vested right" And the voter they lead by his long hairy lugs. They are the pests that I want to indict-

Chanting a ballad whose burden is bugs.

ENVOY.

Prince, our exploiters, with insolent spite,

Picture the farmers as mossbacks and thugs, But you, if you knew them, would pity their plight, Chanting a ballad whose burden is bugs. 


\section{LVI.-The Whole Bunch}

LL the signs seem to be right for doing a bulletin on the farm live stock. During the past week three correspondents have asked me about Sheppy and old Fenceviewer, and last night at milking time the whole aggregation forced themselves on my attention. It happened this way: In the afternoon two little pigs that are taking the rest cure and fattening for winter pork, managed to break out of their pen in the orchard and raid the shed where the chop feed and skim-milk are kept. As no one had time to fix their pen they were put in the cowstable for safe keeping. That started the whole chain of circumstances. When it came milking time we couldn't put in the cows because of the pigs. We had to milk in the field. While the milking was in progress the colts came galloping up to nose around for salt and they scared the cows. I started to throw clods and sticks at the colts to drive them away, and that started the turkey gobbler swearing at me. By the time I 


\section{THE RED COW}

got the colts scattered and the cows gathered again I found that a titled cat was helping himself from the pail of milk that I had incautiously placed on the ground. Just because there was a nail loose in the pigpen I got in trouble with all the live stock. Hence this article. I have a feeling that there is a moral connected with that-let me see. Isn't there an improving tale about the horseshoe nail that was lost which caused the horseshoe to be lost, which caused the horse to be lost, which caused the man to be lost, etc.? Anyway, I didn't stop to puzzle out the moral. I simply kicked the cat in the wishbone and resumed the task of milking a fly-bitten cow with an active tail. In the humour $I$ was in she was mighty lucky that I didn't kick her, too.

I don't like to accuse cows of being interested in politics, but they are acting very much like it. For the past week they have been doing a lot of bawling, both by day and by night, and I can't for the life of me make out what they are bawling about. That sounds as if they were indulging in political discussions, doesn't it? Besides, one day last week Fenceviewer II. bolted the convention. Word was brought to the house that she was missing from the pasture 


\section{THE WHOLE BUNCH}

field. As I was busy at something else I sent the two littlest boys to hunt for her. Not being versed in the guile of cows and being full of youthful pity they went to the well in the woods to see, if by any chance, she had fallen in. When I got through with my chore I joined the hunt, but I didn't go to look in the well. No, indeed. I headed straight for the oat field. I didn't know how she could get in, but as the oat field was the nearest point where she could get into mischief I knew she would be there. And I was not disappointed. As soon as I reached the field I saw her horns and the red line of her back above the waving heads. A hurried investigation showed that she had entered by the Government drain. The last time the drain had been flooded a lot of grass got caught on the barbed wires that served as a water fence, and not only covered the barbs, but weighed down the wires so that she could step through. Calling the boys to help me, we drove her out and fixed the fence. Now, wouldn't you regard the action of that cow as having a political colouring? She left the others to get into a place where the pasture was better-a customary political move. But I hope the cows do not become too political, for I have noticed that political leaders are so confused 


\section{THE RED COW}

that they no longer favour us with illuminating interviews, and $I$ am afraid that if the cows get too much mixed up they will not give down either.

* $* *$ * * $*$

Of course, I may be wrong in accusing the turkey gobbler of cursing, but I do not think so. No matter what language man uses, if he spedks as earnestly as that gobbler and in the same tone of voice, it is perfectly safe for a policeman to run him in on a charge of using "profane and abusive language," and the court interpreter will show that he was right. Moreover, the gobbler has had family troubles to try his temper this summer. Two flocks of his children were raised by hens, and in spite of his strutting and blandishments they refuse to have anything to do with him. Instead they obey the clucking of the mother hen, and "tweet" disdainfully at their haughty sire. In addition, his lawful spouse doesn't seem to care to have him around while she is looking after her flock. She is apparently a suffragette and quite competent to look after her own affairs. Even when a thunderstorm comes up the youngsters do not turn to the old man for protection. That led to a rather pathetic picture a short time ago. A sudden storm roused the paternal 


\section{THE WHOLE BUNCH}

instinct in the old fellow. Taking his place near the little flock he spread out his tail and ample wings so that they touched the ground and offered an excellent shelter, but the ungrateful creatures refused to notice him. No wonder his temper seems to have gone bad. He is forced to flock by himself and the lonely life leads him to brood on his wrongs. Since the beginning of the hay harvest he has roosted on the front ladder of the hayrack, and when either man or beast has passed him he has gobbled viciously and "cursed them by their gods." If there is any truth in the old saying that curses, like chickens, come home to roost, that turkey will have a terrible time of it if the curses he has uttered this summer ever decide to hold an old home week. Though he is a big bird, only a small percentage of them will be able to find a roosting place.

Even though Sheppy did noi figure in the rumpus when I was chasing away the colts that scared the cows and led to my kicking the titled cat, he was in the offing, with his tongue hanging out. $\mathrm{He}$ had done his work of bringing the cows to the pasture gate, and was in a position to watch the disturbance with the air of one who had done his work properly and did not need to concern himself with vulgar 


\section{THE RED COW}

rows. At the present time Sheppy lacks something of his customary steam owing to a rather serious blood-letting. One afternoon he came to the door with blood dripping freely from the end of his tail. I thought he would be competent to look after his wounds, but I was mistaken. When next I looked at him the blood was still flowing freely. On catching him I found that he had somehow severed an artery in his tail, and I had to improvise a tourniquet to stop the flow. Everything was satisfactory until next day, when the tight cord seemed to hurt him. He worried it off with his teeth, and the blood started to spurt again. After I had bound up his wound again I started to investigate to find out how the accident occurred. Happening to remember that the mowing machine was standing in the barnyard, with the mowing-bar in the air, I examined it. Between a guard and a blade of the knife $I$ found a bunch of Sheppy's hair. Evidently when passing the mower he had wagged an affable tail against the knife and it had got caught. In getting away he almost clipped a couple of inches off the end of his tail. He hasn't seemed so spunky since losing so much blood, but if there is anything in ancient medical lore, he probably stands the heat better. 


\section{LVII.-Human Nature in Dumb Creatures}

T $T$ is a mistake to suppose that any quality, habit, trick, failing, weakness, virtue or other 1 characteristic is peculiar to mankind. The dumb creatures about the place have every one of them. If I were to watch them carefully I feel sure that I could find instances of everything from the Seven Deadly Sins to the Seven Cardinal Virtues, and that without leaving the barnyard. It is all very well for us to talk about getting rid of our animal natures as if that would mark an upward step in our development but what interests me is how to rid the dumb creatures of what can only be described as their human natures. It is always the human things they do that arouse my wrath or make me laugh. For instance, our old gobbler gives every evening one of the most human exhibitions of over-bearing meanness that I have ever witnessed. I thought it was only society people, and a particularly annoying brand of them at that, who had the habit of waiting until other people were comfortably 


\section{THE RED COW}

seated at a concert or theatre and then walking in, disturbing every one and perhaps making quite a few get up to make way for them as they progressed towards their seats. I thought this trick was confined to people who wished to show their importance, and new clothes and didn't mind how much they bothered other people. But since watching our gobbler going to roost $I$ have come to the conclusion that this kind of conduct on the part of society people at public entertainments is not due to vanity or a desire to show off but to fundamental cussedness and a wicked delight in causing as much discomfort as possible to other people.

* * * *

The old gobbler has become expert at ascending the roof of the stable and not only does the trick with ease but puts frills on it. When roosting time comes round each evening, the mother hen and her flock of young gobblers and hens go to roost quietly and circumspectly like ordinary folks. The old gobbler, on the contrary, waits around and picks up grains of oats about the stacks and hunts for crickets and keeps up an air of being busy until it is almost dark and the rest of his tribe are settled for the night-or think they are. When he finally makes 


\section{HUMAN NATURE IN DUMB CREATURES}

up his mind that it is bedtime he stretches his neck a few times, first in one direction and then in another, and takes a look at the top of the stable with one eye and then with the other and at last makes a flying leap or a leaping fly that lands him on the ridge-board. That would be all right if he were satisfied after he got there, but he is not. He insists on roosting on the extreme north end of the ridgeboard and he always flies up on the south end. There is no reason why he should not fly up at the north end but he never does it and I am inclined to think from watching his actions that he flies up on the south end on purpose. Anyway, as soon as he gets up and gets his balance he starts to walk towards the north along the ridge-board. As soon as he comes to the first of his offspring he gives a sharp peck with his bill and the youngster gets up squeaking and moves along ahead of him. Presently he has them all huddled on the ridge-board along the north end and the fun begins. The polite thing for him to do would be to step down on the shingles and walk around them, but does he do it? I should say not. $\mathrm{He}$ gives the nearest youngster a vicious peck that makes him jump in the air and land sprawling a few feet down on the shingles. In rapid succession he 


\section{THE RED COW}

deals with the fourteen youngsters and their mother in the same way and for a few minutes the roof is covered with squeaking, sprawling, protesting turkeys. As he pecks them out of his way he walks along the ridge-board to his chosen roosting place and when he finally reaches it he stretches his neck arrogantly while the others scramble back to the top and settle down for the night. When they have settled down the old bully settles down also with as much dignity as a dowager who has disturbed a whole seatful of music lovers at a concert or opera. You needn't tell me that there isn't something human about a gobbler that does such things as that.

$$
\text { * * * * }
$$

Then there is the little cow-the one whose praises I have sung as the Kerry cow. You would think to look at her that butter wouldn't melt in her mouth. She looks like a pet and to a large extent has been a pet. At first she wouldn't allow any one but me to milk her and would bawl if $I$ attended to any of the other cows first. You never saw a more demure, harmless and even helpless looking bit of a thing in your life. Yet she is a base deceiver. She needs more watching than any cow on the place. Not only is she more prone to mischief than old 


\section{HUMAN NATURE IN DUMB CREATURES}

Fenceviewer I., but she sneaks into it instead of doing it boldly like that competent and fearless old pirate. My pampered pet is an exasperating little sneak that cannot be trusted for a minute. Not only will she get through gates and doors whenever she gets a chance but if she happens to get into the stable when another cow is tied she will immediately start to put a horn through her. When putting in the cattle at night we have to be on the watch lest our demure little cow should happen to get another in a corner and start prodding her. And when you catch her at her tricks she jumps to her own stall and looks so meek that you can almost imagine she is saying "I didn't do nuthin'." If that kind of conduct on the part of a cow is not human I should like to know what it is.

* * * *

Sheppy, being an intelligent dog, has a lot of characteristics that we flatter ourselves by calling human. For instance, he has an orderly way of doing things that often attracts my admiration. Now that he has settled down and outgrown the freaks of puppyhood he acts as if he felt himself one of the family, with quite a lot of responsibility on his shoulders. Every morning when he is turned 


\section{THE RED COW}

out he takes a trip around the farm, apparently to see that everything is right. When the chores are being attended to he is always on hand to help drive the cows and after the calves have been fed he doesn't have to be told to drive them away from the fence and scatter them over the field. As soon as the last of them has bunted over the pail from which it has been fed he starts them on their way. All day he is around to do his part in whatever is to be done and when the driver is away he watches till she is coming back and goes down the road to meet her. Just how he knows when she is coming is something of a mystery. Long before any one else can see her behind the trees half a mile down the road, Sheppy will trot off to meet her. And he never makes a mistake about it. When we see him starting for the corner we can be sure that the driver is coming. But there is one bit of his daily routine that is something of a mystery to me. I do not need him and I have nothing for him to do when I go after the mail when the postman has put it in the box, but every morning he is waiting for me and marches to the mail box ahead of me. I cannot make out why he does it unless he is hoping that some day he will get a letter-a letter with a bone in it. 


\section{LVIII.-Early Observations}

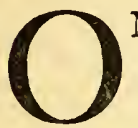

$\mathbf{N}$ mornings when I happen to be wakeful the observations I make are not always through the tent flap. Many of them are through the sides of the tent, and I hear them instead of seeing them. As you might expect, the first morning sound is the crowing of the roosters, and let me tell you that it is no trifling sound on the farm at present. Between thirty and forty broilers are practising crowing and there seems to be a very sharp rivalry among them. Some of the older ones can crow almost as lustily as the father of the flock, while a lot of young fellows cannot manage anything better than a hasty mixture of a squeak and a squawk. You know, of course, that the scientists are unable to offer any explanation of the foolishness of roosters in crowing like this and telling their enemies where they are. One morning recently I was awakened by the crowing of the young roosters about an hour before dawn. The racket they were making recalled to my mind the fact that 


\section{THE RED COW}

we were expecting visitors that day and that broilers would be in order for dinner. I "obeyed that impulse" at once, got up, lit the lantern, and started on a raid. All I needed to do was to listen and locate the lustiest crowers where they were roosting in the apple trees. Then $I$ went around and picked them off the branches until $I$ had half a dozen plump ones stowed away in a coop. If they hadn't reminded me of their existence by their fool crowing they might still be alive and scratching gravel with both fect for admiring young pullets.

When the first light of dawn appears the young ducks begin to jabber, where they are spending the night in a packing box under an apple tree. A few minutes later I have a chance to make my first observations through the tent flap as they march loquaciously past in single file. Now that the mornings are getting cool, sometimes with a touch of hoar frost, the crickets, beetles and other innumerable insects are sluggish, and the ducks seem to know just where to look for them in the long grass. That reminds me that the wise old fellows who made up our proverbs were not always careful observers of natural phenomena. We have been told that it is 


\section{EARLY OBSERVATIONS}

the "early bird that catches the worm," but the observations I have made lead me to believe that for one worm that suffers for his folly in being out late a thousand bugs and beetles are captured. The proverb should read, "It is the early bird that catches the bug," and different birds have different ways of going about it. When a duck goes after a bug he acts much like a ball player trying to steal a base. He throws himself forward so suddenly that he lands on his stomach, and at the same time shoots out his neck full length. When I umpire such an action through the tent flap it is very seldom that I could announce the bug "safe." If ducks could only be taught to play baseball they would beat $\mathrm{Ty}$ Cobb at stealing bases. Shortly after the ducks the turkeys come marching past on their morning bug hunt. Instead of moving in Indian file they walk abreast in extended formation, and their method of taking the unwary bug is entirely different from that of the duck. When a turkey sees his prey he stops still, sometimes with one foot in the air. Slowly and almost imperceptibly he moves his head towards the luckless bug, and when his beak is within a couple of inches of it he makes a quick grab that is invariably fatal. In this connection I sometimes wonder 


\section{THE RED COW}

if my attitude as a nature lover is entirely correct. The bug probably enjoys life just as much as the turkey, and I wonder if the bug should not have my sympathy rather than the birds. But that is a delicate point which I am willing to leave to professors of ethics and other subtle reasoners.

Although the roosters are apparently the first of the domestic fowls to waken in the morning, they are usually the last to get up, or, to be more exact, to get down. When they start to lead out their pullets in the twilight $I$ have a chance to see that at least one maker of proverbs was a close observer of nature. I have heard it said of ladies who walk with a mincing gait that "she steps out like a hen before day." As I observe the hens through the tent flap I notice that their gait differs from the gait they use later in the day. They pick up their feet carefully, and hold them poised for a moment before putting them down daintily, and they hold their heads up in a way that looks very haughty. The philosopher who originated that simile must have been an early riser, or perhaps he also made his observations through a tent flap, with the blankets tucked cosily up to his chin. But some mornings I make observa- 


\section{EARLY OBSERVATIONS}

tions through the tent flap that I cannot stay in bed to meditate on. Through the tent flap I have an excellent view of the haystacks and the stack of oat sheaves. One morning when I opened a lazy eye in the early dawn I was suddenly brought wide awake and sitting up, as the Red Cow and her progeny were among the stacks. The sleepy inhabitants of the tent were immediately rousted out, and for the next few minutes we took the Kneipp cure together while sending Fenceviewer I. and her family back through the gate she had managed to work open. On another morning my first observation was of a team of horses that had come in from the road and were trying to founder themselves on our fodder. Luckily Sheppy was loose and he attended to their case without making it necessary for me to do anything more than whistle for him and yell, "Sick 'em!"

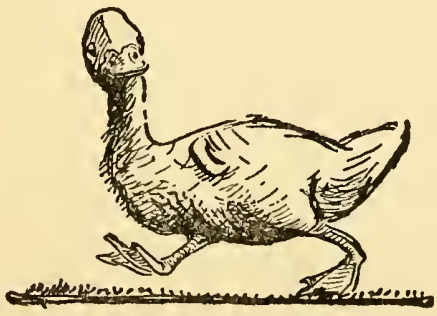




\section{LIX.-Bantams}

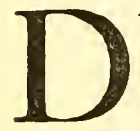

URING the Christmas season a friend sent the littlest boy a pair of bantams, and there is now more spunk on the farm than there has been since my boyhood days, when I used to own a sassy little hen that bore the Gaelic name of "Prabbach." I don't know exactly what the name meant, but it seemed to fit her exactly. These modern bantams appear to be of aristocratic descent, with feathers down to their toes, and the rooster has a haughty bearing that makes me take liberties with "Will Waterproof's Lyrical Monologue," in order to describe him properly:-

"The Cock was of a prouder egg

Than modern poultry drop,

Stept forward on a firmer leg,

And crammed a plumper crop.

Upon an ampler dunghill trod,

Crowed lustier late and early,

Sipped wine from silver, praising God,

And raked in golden barley." 


\section{BANTAMS}

The little bantam can crow quicker, oftener and with more ginger than any other rooster on the place. He has so much steam that I imagine he must have the spirit of a full-sized Brahma or Cochin compressed into the size of a pigeon. He is so cocky that his very appearance scems a challenge. The first time he stepped out into the barnyard the turkey gobbler challenged him to mortal combat and unlimbered for action without waiting for his challenge to be accepted. But, try as he would, the gobbler could not land on the brisk bantam. The little fellow sidestepped every swipe that was made at him, and went on picking up grain as if it were only a fly that was bothering him. And when he scratches in the straw for grain he does it with a vim that seems to say to all the world, "When I scratch gravel mind your eye." But if I could speak hen language I would feel it my duty to warn him about his little mate. She looks so demure that I suspect her of being a flirt.

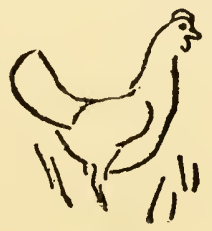




\section{LX.-A Little Tragedy}

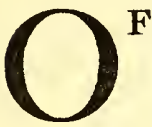

F ALL the youngsters in the barnyard the chickens are the most attractive. They are fluffy little balls of down of most engaging appearance, and I don't blame Beatrice very much because she shows a longing to eat them. She is allowed out for a run with "her nine farrow" every day, and she has to be watched carefully to keep her away from the chicken coops. Yesterday she went over beside the road to pasture, and the boy who was watching her thought she was safe, but as soon as he took his eye off her, she made off to a neighbour's barnyard, attacked a chicken coop and got a couple of chickens. I haven't faced the music about that yet, but Beatrice will get me into trouble unless we hurry and make a proper pig run, where she and her greedy little wretches can get around without getting into trouble. The little pigs are now beginning to eat out of the trough with their mother, and sometimes she chases them off with a howl of rage that hasn't a trace of maternal ten- 


\section{A LITTLE TRAGEDY}

derness in it. In a few weeks she will rob her own children of their feed unless she is restrained, for "pigs is certainly pigs." As soon as her flock is weaned she will be an outcast with none so poor to do her reverence. No one will have any compunctions about putting her in a pen and fattening her for bacon. But as long as swill and chop-feed are plentiful she will not mind the lack of affection. She will grunt contentedly when she is full and complain bitterly when she is hungry, and she won't care a hoot whether she is loved or not.
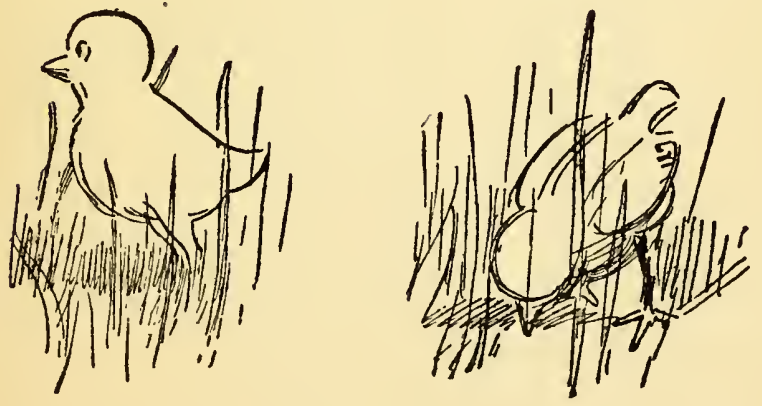


\section{LXI.-A Scientific Query}

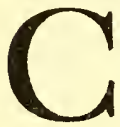

AN any one tell me why it is that hens always sing when fed on corn on the cob. We had been feeding them oats, bran, and occasionally wheat, and they took to it in a matter-of-fact way, but when a few cobs of corn were thrown out to them they pecked at it and sang as if their hearts were overflowing with joy. Since noticing this peculiarity $I$ have watched them at every feeding, and it is only the corn that arouses them to music. I also had a chance to make a further observation on the ducks. One of them got, a small ear in its bill and started away on a swift waddle with the rest of the flock trailing behind. Instead of trying to find a quiet corner where it could enjoy its meal it made straight for the mudpuddle and dropped the ear in the center of it. The corn immediately sank out of sight and the whole flock of ducks crowded around to get at it. Judging from the noise they made they must have been enjoying themselves hugely, and I am led to do a 


\section{A SCIENTIFIC QUERY}

little speculating of a scientific character. We are told that hens should be fed in straw or chaff so that they will get plenty of exercise with their meals. I wonder if it wouldn't be a good idea to feed the ducks in a convenient mud-puddle so that they can develop themselves properly. I await an authoritative verdict from some one who knows.

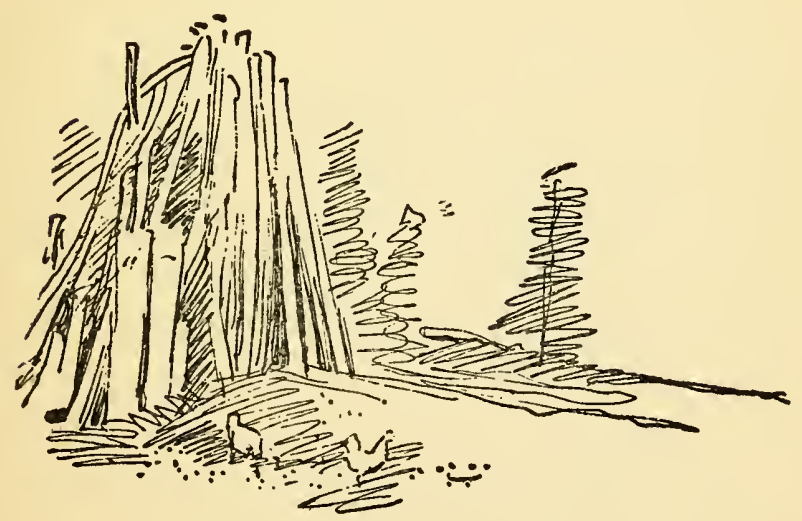




\section{LXII._A Poultry Note}

TT $\mathrm{HEN}$ the chickens that were rounded up from the apple trees last week had served the necessary time in confinement to make them get accustomed to their new roosts they were turned loose, and there was more excitement. A young cockerel thought he would celebrate the occasion by crowing, but immediately seven young gobblers started for him on the jump. Every time he would start to crow the gobblers would rush in on him, and the last I saw of him he was going over the fence into the pasture field with the gobblers after him, but he looked as if he were going to crow even if he died for it. By the way, I have lost the address of the man with whom I swapped gobblers last fall, but if this should meet his eye I wish to tell him that the "Bubblyjock" he sent has developed into a noble bird. Nothing of his size in the turkey line has ever been seen on the farm, and as he is always first in whenever the chickens or ducks are being fed he is in prime con238 


\section{A POULTRY NOTE}

dition. Some day when I feel equal to the task I shall try to catch him and weigh him, but I have considerable respect for the wings of a turkey-gobbler ever since one managed to give me a sideswipe across the bridge of the nose some years ago. $\mathrm{He}$ not only knocked off a bias patch of skin, but gave me a couple of black eyes that kept me at home for a week. As the present lord of the barnyard is such a husky specimen I am not anxious to take any chances.

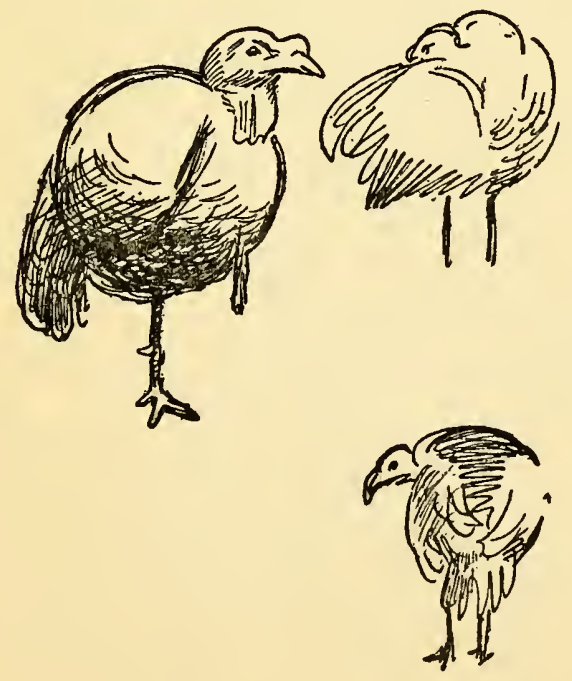




\section{LXIII.-S Spring and the Livestock}

HE winter certainly appears to be over, and neither man nor beast is sorry. We have all been penned in altogether too long, and it feels good to be out in the open again. I notice that it affects the farm creatures in different ways. The cattle seemed unusually lazy, and during the heat of the day most of them lay down where they could let the sunshine soak into their skins. The colts started on a wild scamper around the fields and threw up mud in a way that made it necessary to close them up in the barnyard again, as they were cutting up the pasture. As they abused their freedom they had to be deprived of it. The sheep took things quietly, as might be expected, and I noticed that after a little run fat little Mary Belle stood panting with her mouth open. She and Clarissa and Strafe made a start at playing king of the castle on an ant-hill, but their mothers kept so close to them that they spoiled the fun. Beatrice seemed to like the heat about as well as any- 


\section{SPRING AND THE LIVESTOCK}

thing on the farm. She picked out a snug spot on the south side of what is left of the straw stack, and grunted pleasantly, while the sunshine tickled her fat sides. During the cold weather she made frequent investigating trips around the farm, but the heat seems to make her lazy. The most belligerent creature on the place is the turkey cock. He struts and gobbles and makes thunder with his wings in a most awesome way. Those who do the chores have suggested that if he continues to be so threatening we shall have to put a ring in his nose and lead him around on a chain. He is certainly a noble bird. 


\section{LXIV.-First Snow}

HE snow was a surprise to all the youngsters of the barnyard. There had been flurries earlier in the season, but nothing to compare with the depth that now covers everything. When the colt was turned out he left the stable door at a run. His hoofs threw up a cloud of snow that frightened him, and he ran through the gate to the pasture field. The more he ran the more snow he threw up and the more scared he got. He galloped around the field until he was winded or decided that there was nothing to be frightened about. Then he obeyed an old instinct, pawed away a little patch of snow and began to eat the frozen grass. It was his first experience of snow, but he knew what to do in case he should be obliged to live on the pasture it covered. The colt was not the only youngster to have a first experience of snow on that morning. A flock of young pullets that have been accustomed to ranging freely over the farm were completely flabbergasted by the 


\section{FIRST SNOW}

situation. They huddled at the door of the henhouse, and whenever they tried to travel they did it a-wing. As they were not used to this method of locomotion they misjudged distances and fell protesting into the snow, where they stayed for a while before trying to walk. The young ducks that sleep under the granary did not venture on the snow until Sheppy routed them out on one of his investigating excursions. Even though nature has provided them with snowshoes in their web feet they preferred to try their wings, but they are so fat and heavy that their flying was a flat failure. They quacked across the barnyard with heads up and wings beating wildly, but their cute little tails and flat feet were still in the snow. The young turkeys also took to flying, and though they were more expert than any of the others the result was the same. They landed in snowdrifts and looked unhappy. One young gobbler landed on top of a haystack, where he stood up to his wishbone in the snow, waiting for a thaw to come and rescue him. I left him until the chores were done and then rescued him by pelting him with snowballs. Of course, this trouble about the snow lasted for only a day or so. Ducks, hens and turkeys now get around much as usual. 


\section{LXV.-A "Skift" of Snore}

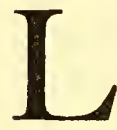

AST night we had a "skift" of snow, and it was interesting to notice the effect on the summer-born creatures of the farm. A plump young kitten that had not seen the pesky stuff before came to meet me from the stable, jumping like a rabbit. At the end of every jump she would stop and say "Muhr-reowr!" in tones that seemed several times too large for her body. When I reached her she stood lifting one foot after another and shaking off the clinging flakes, only to get a fresh supply every time she put a foot down. Of course it was mean to roll her over in the snow, but I have no doubt it gave her an appetite for breakfast and could be defended on the best hygienic grounds. About the first thing $I$ noticed about the snow was that my new winter boots do not promise much comfort, for as the snow melted on them my toes got so cold that I had to step cautiously for fear they would snap off like icicles. The young turkeys were complaining noisily from the apple 


\section{A "SKIFT" OF SNOW}

tree where they roost at night, but evidently thinking that my appearance at the barn meant the near approach of feeding time, they started to fly the full distance. They seemed to realise that the white stuff on the ground meant cold toes for them, but they didn't improve matters much by flying. They landed on top of the hay stacks where the snow seemed to lie the deepest, and on top of the granary, where they clawed around on the slippery surface and mussed themselves up generally. A chilly turkey is just about as unattractive looking a bird as any one would wish to see. They fluffed up their feathers so as to get a layer of entangled air around their bodies, hunched up their shoulders and pulled in their necks. Really they looked more like turkey buzzards than like Christmas dinners, but a month of high living on corn meal and shorts will doubtless make them fit for the market.

The colt had an especially good reason to be grouchy about the sudden change in the weather, for he had been out in it all night, and the soft snow had frozen into lumps on his back. He was so bad tempered about it that he even let his heels fly at his mother when she came near him, and the way he lay 


\section{THE RED COW}

back his ears at the approach of the yearling showed that he was willing to fight him at a moment's notice. The yearling, however, seemed to know what to do in such a case. When the sun began to rise he started to gallop around the field snorting and kicking at imaginary enemies. As I watched his exhibitions of speed I couldn't help wondering if he could be made to show any of it under a harness. His mother is a sedate dowager who often shows plenty of speed when $\mathbf{I}$ go to catch her in the pasture field, but in the harness nothing short of a black snake whip can get her off the "cord-wood trot." The colt was watching the yearling's antics, and at last he couldn't help joining the fun. With tail in the air he started after his big brother, and they galloped all over the pasture, kicking at one another and snorting. When they tired of their play they were comfortably warm, and went to the bank of the Government drain, where there was long grass that was free from snow, and proceeded to have breakfast. After this the colt will probably know that when the ground is white the finest thing in the world to make him feel comfortable will be a good, brisk run. 


\section{LXVI.-A Spring Shower}

FEW days ago we had an ideal shower, warm, still and occasionally shot with sunshine. The necessity of doing the chores drove me out of it and I was glad. Putting on an old overcoat that did not owe me any money, and an old felt hat, long innocent of the block-it showed a quarter pitch from the peak to the brim-I slopped around for a happy half hour. But, though I was happy, the ducks were happier. They were not only in their element, but they were enjoying a banquet. The frost had come out of the ground and the angle-worms had come to the surface. I don't think the ducks missed one of them-all of which made me try to remember whether Darwin in his study of earthworms noted their economic value as poultry food. The hens are every bit as fond of them as the ducks, but they are not so fond of the rain. But there are other things that like to feel the warm, splashy drops. I had to turn out the cows for a drink, and 


\section{THE RED COW}

the day seemed to suit them exactly. While old Fenceviewer I. was waiting to have her stall cleaned and her bed made up she humped her back against the shower and chewed her cud, and if she could have had a couple of hands stuck into pockets she would have made a perfect picture of contentment. And all the while I could hear the birds twittering and calling in the rain, and making different music from the kind we hear while the sun is shining. I was really sorry when the work was done and I had to clean my boots and put off my wet things and listen to a lecture on the chances I had taken of catching cold.

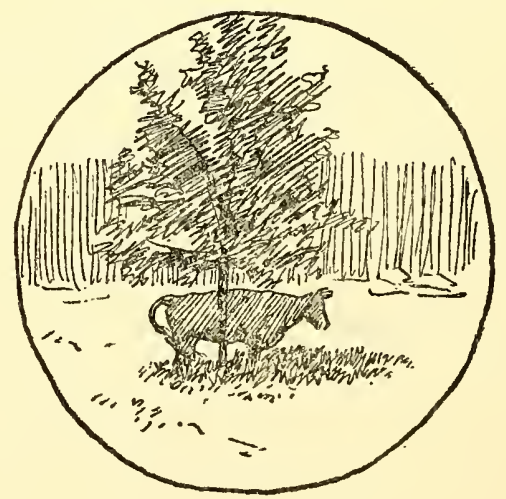




\section{LXVII.-Doing Chores}

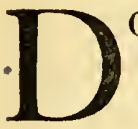

OING chores is a routine job, and even the animals seem to be getting it down to a system. When I go out to feed the cattle in the morning Sheppy meets me at the door and insists on having a play, which consists mostly of jumping up against me as if he were a wolf trying to catch me by the throat and drag me down. My part of the game is to catch him off his guard when his feet are off the ground and give him a push that bowls him down. After he has had a few tumbles he is satisfied, and begins running around in wide circles. When I get near the stable the kitten that the children have named after an eminent statesman gets on the path in front of me, purring and rolling on his back so that I can tickle him with the toe of my boot. As soon as I begin to open the stable door the driver whinnies "Goodmorning," and a moment later the Jimmie-cow bawls complainingly, and says in part: "Why _- are you so late coming out to feed us this morning? 


\section{THE RED COW}

Get a wiggle on you with those cornstalks!" Of course, it is all very foolish, but when one is attending to the wants of a lot of animals he gets about as well acquainted with them as he does with people, and, as I have remarked before, they all have very human attributes. Human nature can be studied in farm animals just as easily as in city crowds-and you do not have to be so extravagant with your expense account. 


\section{LXVIII.-Fishing}

V THAT would spring be to a small boy without fishing? At the present writing fishing is at high tide, though we are still living on the same old fare. Although fish-lines and hooks have been bought, fishing-poles trimmed to shape with the butcher-knife and loads of bait dug, I have yet to see an actual fish. I cannot deny that years ago I used to get plump chub in the Government drain, and one year some carp weighing five pounds and over came up with the spring flood, but it is long since I have seen anything bigger than a minnow. Still, the littlest boys know that there were fish in the drain once, so why not now? There is a spot about half a mile away where willows were allowed to grow on the bank and the spring floods scooped out holes in which driftwood accumulated. In these mysterious depths fish are supposed to hide, and a baited hook will be stripped of its bait in a few minutes. There is no lack of nibbles that appear to give the 


\section{THE RED COW}

old-time thrill, but it is no use explaining that minnows less than two inches long, that are too small to be hooked, are the fish most active in this kind of work. I know that they are just as likely to catch a finnan haddie or dried codfish or canned salmon as a fish of any size, but I wouldn't dampen their ardour for anything. As a matter of fact, I ain inclined to approve of their enthusiasm, for I find that the chores go through with a rush since the fishing began. All I need to do is to let them wring a reluctant promise from me that if they hurry through with the chores they can go fishing. After offering enough opposition to make the favour seem great I give a grudging consent and the chores go through with a rush. And at bed-time (new time) a couple of wet and muddy boys come home, very tired and very hungry. Though they bring no fish they have had such monstrous bites that they are sure there are big fish there, only they are too cute to swallow the baited hooks. Some day they are going to catch a whale, and then they will show me. What would youth be without its faith in the possibilities of fishing and such things?

Right here an interruption has occurred. I might have known when I was writing that first paragraph 


\section{FISHING}

in such a superior way that something would happen, but the truth must be told even though wisdom be confounded. A few minutes ago a boy bulged through the kitchen door waving a string of fish and registering triumph. He found the right fishinghole at last and caught eight, and one big one-Oh, a beauty-got away. I hadn't a word to say. I examined them and was forced to admit that he had eight as fine chub as I had ever seen taken in this district. The longest measured seven and a half inches and the shortest six inches. Fishing is now on a firm basis and the food outlook has greatly improved. There is a fish banquet being arranged, and the titled cat was so excited at the prospect of getting eight heads to chew at that he had to be put out. But though my predictions have all gone wrong and the faith of the boys has been justified, I am not without compensations. The chores will now be done with more steam than ever and the fishing season may last all summer. If they can only catch a few now and then to keep up their interest, they will not need to be driven to any kind of work. The promise of permission to go fishing as soon as a job is done will be enough to get them to do their best. I hate driving them and it will be 


\section{THE RED COW}

a real pleasure to have their minds so set on fishing that they will do their work eagerly so as to win their freedom. I hope the fish supply lasts right through the corn-hoeing season. By the way, I am not sure but it would be a good plan to have the drain stocked with fish so that there would be a sure supply every spring. I must think about it. 


\section{LXIX.-A Lonesome Squirrel}

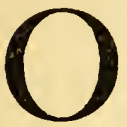

NE wet morning recently $\mathrm{I}$ happened to be passing through the wood-lot, when I heard the squawking of a black squirrel. I rejoiced to think that perhaps the squirrels were coming back, but investigation revealed only one lone specimen, and, judging by its size and actions, it had wandered far from its mother. It was crying from pure lonesomeness, and it didn't care who heard it. At the best the cry of a black squirrel is about the saddest thing in nature, but to hear it when the trees are dripping and the woods gloomy it is the last note of sorrow and pessimism. I have never seen an attempt to render this sound in letters, but what of that? We shall try it now. As nearly as I can arrive at it, the sound should be represented somewhat as follows:

\section{"ku-ku-kwanh-h-h!"}

The last syllable is long drawn out in a most desolating manner. Come to look at it, this attempt to 


\section{THE RED COW}

render the cry of the black squirrel has a sort of pluperfect look, and I have no doubt that a skilled philologist could trace it back to an Aryan rootbut I digress. Anyway, my squirrel was squawking and bawling in the universal language of childhood. In the words of the poet, he had "no language but a cry." After spying him I began to edge closer to observe his actions. He frisked about as I approached, and whenever I stood still he began to cry again. When crying he always clung to the tree, with his head downwards, and with every syllable he gave his tail a little jerk. I might say that he was scolding at me, if it were not for the plaintiveness of the noise he was making. Every few minutes I took a few steps nearer, until at last I was within twenty feet of the half-dead maple from which he was pouring his woe. Although I was quite evidently "viewed with alarm" in the most approved editorial manner, he shifted his feet a little from time to time and kept up his wailing. Finally I sat down under the shelter of a tree trunk and continued to watch him. He scolded and squawked and then began to come down the tree, inch by inch, precariously moving headforemost. I kept perfectly still for some minutes-keeping a position of abso- 


\section{A LONESOME SQUIRREL}

lute rest is about the easiest thing I do-and inch by inch he slipped down the tree until he was so close that I could see his beady black eyes and see half way down his throat when he opened his mouth to squawk. At last he got as far down as he cared to come, and continued to tell me about his troubles. I was sorry that I couldn't think of anything to say or do that would assuage his lonesomeness and grief, but when I heard the call for dinner at the house, and knew that I should be stirring, I flung a little parody at him:

"Is it weakness of intellect, Blackie?" I cried, "Or a rather tough nut in your little inside?" With a shake of his poor little head he replied, "Ku-ku-kwanh! Ku-ku-kwanh!"

When I rose to my feet he rushed headlong into a nearby hole. But let no one imagine that my time was wasted while sitting watching that squirrel. Although he was unable to say anything of importance to me, and I was unable to say anything of importance to him, you may note that the interview was good for one extra long paragraph. I could have gone out and interviewed some eminent human without getting any more copy than I did from my lonesome little black squirrel. 


\section{LXX.-Fall Poultry Troubles}

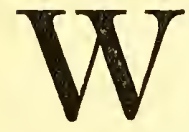

$\mathrm{HY}$ is it that hens always want to roost over the cows and horses in the winter time? Perhaps they want company in the long, lonesome nights, but probably it is because the cattle generate a certain amount of warmth that makes the beams above them pleasanter roosting places than the hen-house. Anyway there is always a week or two at the beginning of each winter when a bunch of ambitious hens must be trained to roost in their own quarters instead of in the stable. Every night at milking time I shoo them out until they finally get it into their heads they are not wanted. But they are almost as hard to convince as the New England farmer who went to a dance to which he had not bcen invited. He overlooked the lack of invitation, and was even willing to overlook the fact that he was told that he was not wanted, but when he was finally thrown outdoors and kicked through the front gate, "He took the hint and went away." After being thrown 


\section{FALL POULTRY TROUBLES}

out of the stalls about a dozen times the hens finally took the hint, and they now stay in their own quarters. But just as I got rid of the hens the guinea fowl decided that the weather was getting altogether too severe for outdoor life. All summer and fall they have been living in the fields, and any one who happened to see them reported the fact much as if they had seen a flock of quail. They really seem more like wild than domesticated fowl, and if they live entirely on insects and weed seeds they must have a distinct value in keeping pests of various kinds in check. But when the cold weather came on they began attending the chicken feedings, not only at home but at neighbouring farms. They seem to have good ears as well as wonderful appetites, for whenever they hear other fowls squabbling over their feed they take to their wings and never touch the earth until they light right in the middle of the banquet. And they never miss a feeding time at home either. They should be fat enough for the table before long.

$$
\text { * } * * *
$$

But what I started to tell about is the persistence the guinea fowl show in adopting the stable as a home. On the first cold night I found the whole 


\section{THE RED COW}

twenty of them ranged decoratively on the partitions between the stalls. I couldn't shoo them away like the hens. I had to touch each one, and as I touched it it gave a shrill squeak and flew blindly until it brought up against the wall at the far end of the stable. Usually they fell to the floor, but sometimes they would beat their wings and work their feet and apparently walk up the wall like flies until the roof checked them, and then they would sink to the floor with a final discouraged squeak. Once I caught one of them to see how heavy it was, and it squealed like a rat. I dropped it instinctively, for I felt that anything that could squeal like that would be likely to bite. And they can bite-or at least use their bills. I have noticed that at feeding time they can whip even the rooster away from the choicest bits, and I am told that when there were young chickens about, the old pair of guinea fowl thought nothing of grabbing them in their beaks and shaking them as a terrier shakes a rat. Sometimes, if they were not interrupted in committing these atrocities they even killed the chickens. I do not think the nature and habits of guinea fowl have been studied by the experts, and some time when the rush is over I may prepare a bulletin on the subject. At present, how- 


\section{FALL POULTRY TROUBLES}

ever, I am chiefly interested in making them understand that they are not wanted in the stable at night. But is seems hard to convince them. Every night $I$ find them in exactly the same position as on the first night, and every evening I startle twenty squeaks out of the flock before I get them to move elsewhere. It is getting to be a regular chore.

$$
* * * *
$$

But it is as fabricators of new and fiendish noises that the guinea fowl are in a class by themselves. They are at it all the time. The mildest noise they make reminds you of the filing of a saw with a bungling mechanic dragging the file on the back stroke. The noises they make when they set to work to show what they can do are beyond description. I have heard noises something like them in sawmills when the circular saw happened to strike a sliver. And they are ready to give an impromptu serenade at any time. I used to think that the ducks were the noisiest thing about the barn-yard, but they only squawk when I am trying to talk. The guinea fowl keep at it when I am trying to think so that I cannot bear the thoughts that are trying to whisper their way into my brain. They rasp out wild noises when they are eating and when they are fasting, 


\section{THE RED COW}

when they are walking and when they are flying; and their idea of a nice, quiet time seems to be to lie down in some spot where they are sheltered from the wind by a clump of weeds or something of the sort, and try to outdo each other in the range and volume of their cries. When we start eating these guinea fowl I am going to dissect one to find out what its vocal cords are made of. I don't think they could possibly make such noises without metal contrivances of some kind that can be rasped together and banged and thumped on. Perhaps I'll discover a new metal that would be valuable in making phonographs, and be able to organise a company to mine it out of the guinea fowl. Then I'll sell stock to the farmers. Judging by their noises there are great and unknown possibilities in these creatures. And yet I have heard people say they rather liked having them around because they keep up such a constant clatter that they keep one from getting lonesome. It strikes me that the person who would not rather be alone than have a flock of guinea fowl for company must have a bad conscience. 


\section{LXXXI.-Thanksgiving Day}

\section{$\mathrm{H}$}

ERE is Thanksgiving Day right on top of us, and $I$ am all in a fluster. I am not sure that I am going to be thankful about anything. Isn't that dreadful? But the truth is that in my usual improvident fashion $I$ forgot all about it. While other people were carefully saving up their thankful feelings for the official day, Oct. 20th, I just went along carelessly pouring out my thankfulness whenever it welled up within me. But that is not the way well-conducted people do. They are as methodical about their thanks as the woman in the story was about baths. When she had a stationary tub put in the house she exclaimed to an admiring friend, "It looks so nice $I$ can hardly wait till Saturday night." As nearly as I can judge the world is full of just such careful people, and they never let a speck of thankfulness escape them until the right day comes around. They keep it in through all the long dreary year, and, then on the 20th of October, they will go about expressing it 


\section{THE RED COW}

in a careful and business-like way. Since we have a Thanksgiving day that is naturally the day to be thankful on. People who look at things in that way simplify matters for the Recording Angel. They turn over their thanks in one neat bunch, and the matter is over with for another year. But much as I may admire people who are able to restrain themselves in this way I have no hope of attaining their perfection. Having formed the habit of living each day as I come to it, I may run the whole gamut of moods from boiled down pessimism to overflowing thankfulness between sunup and sundown. And yet -and yet-this way has its compensations. I am not sure that I would change if I could.

$$
\text { * * * * }
$$

I was reminded of the fact that Thanksgiving Day is at hand by seeing some ducks being fed up for the occasion, and by being asked whether the celery will be fit to use on the 20th. As the indications are that both these excellent comestibles will be in prime condition by that time, I find myself bubbling over with thankfulness almost two weeks before the specified time. But I know that is all wrong, and I have set to work to figure out just how to be thankful like other people. To do this I am forced 


\section{THANKSGIVING DAY}

to review the happenings of the year, my hopes, ambitions and enterprises. While at this task I was struck by the thought that if we had a Grumblegiving Day as well as a Thanksgiving Day, it would be much more carefully celebrated. The first thing I thought of was the bugs, blights, pests, weeds and such things that I have been fighting with all summer. As I thought of them Thanksgiving Day seemed very far away. But that mood did not last long. After all they did not injure anything which I was over-poweringly interested in. Life itself is what I am chiefly interested in, and, while we have food, clothing and shelter, it is as good one day as another. I can be just as much alive mentally, physically, spiritually on one day as another. A rainy day is just as good as a sunny day if we manage to get in tune with it. And having got a fairly good hold of the truth that yesterday is dead and to-morrow unborn, I find that I really can not go away from the present day and the present moment to seek the sources of thankfulness. It will be the same on the 20th of October. I must find in it all that I shall be thankful for. I do not think I shall be disappointed. 


\section{THE RED COW}

In order to celebrate Thanksgiving Day in the popular fashion, one would need to keep books and strike a balance of good and evil. Let me try this plan. First, there is the orchard. The frost killed most of the blossoms; there was a plague of green aphids in the spring; over half of the apples we have are scabby and deformed. Wow! If I were depending on that orchard for my happiness Thanksgiving Day would be a day of gloom. But let us look at the other side of the ledger. We have sold our apples for a topnotch price; we are getting more for our thirds than people used to get for their firsts; we even have a chance to sell our culls at a good price to a vinegar factory; the indications are that after all the orchard will yield a larger cash return than in any year of its existence, except last year, when we had a bumper crop of clean fruit and got top prices. Looking at things in that way I guess I can squeeze out a little thankfulness for the 20th after all. Then there is the young orchard. First let me grumble. The young trees came late in the spring; they were all dried out, and wise people said they would not grow; I was so late getting them planted and getting the ground thoroughly cultivated, that I did not get the corn planted 


\section{THANKSGIVING DAY}

between the rows until the middle of June. Now let us look at the other side. Over ninety per cent of the trees grew and put out a strong growth. The nurserymen did not ask to be paid except for those that grew. The corn escaped the frost and ripened splendidly. It is now being husked, and is proving to be the best crop of corn that has been on the farm in years. Tut, Tut! It looks as if I would eat those ducks in a cheerful spirit after all.

$$
\text { * * * * }
$$

There are times when I think that a spirit of thankfulness is born in one rather than cultivated. When looking at things in this way I find it profitable to study the animals on the place. Somehow they seem to be very human in their emotions.

Their feelings are not complicated by efforts at reasoning, and in their every day conduct they reveal their true spirits most amazingly. Take the Red Cow for instance. Nothing seems to discourage her. She is too full of ambition to grumble about anything. If she doesn't manage to steal a march on me to-day she is quite sure that she will be able to do it to-morrow, and that keeps her in a constantly cheerful frame of mind. This year she had set her heart on getting into the corn field which was just 


\section{THE RED COW}

across the fence from the pasture, but never once did she find an open gate or a break in the fence. She saw it grow from the first green sprouts to matured corn and never got a bite. It is now in the shock and being husked, but she still stretches her neek over the fence in the same hopeful way. She is going to get a feed out of that field before the year is out or know the reason why. Even if she doesn't manage it before the stalks are hauled in she'll find a gate open before the snow falls, and dig up the roots that were left by the hoe before she will give up her purpose. A cow like that is really an inspiration on the farm.

She was born that way and life always looks bright to her, because she always has something to hope for. Now, with the new cow, the one I bought, the ease is entirely different. She must have come into the world feeling discouraged. She has faith in nothing, hopes for nothing, and is always in a mournful frame of mind. Though she gets all the pumpkins she can eat and a good bunch of corn stalks every night, she simply can't cheer up. When we open the pasture gate the Red Cow makes a rush for the stable and gets into the wrong stall and eats all she can of some other cow's feed before 


\section{THANKSGIVING DAY}

she is driven to her place. But the new cow stands mournfully in the pasture. It is quite true that there were pumpkins last night and the night before and many nights before that, but she knows there will be none to-night and she bawls dismally at the thought. Finally some one has to go out into the field and drive her in, and when she gets to her stall she no sooner starts to eat than she looks over at what the other cows are having, and as well as she can with her mouth full, bawls complainingly that she didn't get as much as the rest, or that her pumpkins are not as yellow as the others. There is no satisfying her because she was born that way. It'll be the same on the 20th of October as on all other days. I wonder how many people in the country will be like her? As for me, I think I'll put a pumpkin just beyond the red cow's reach and cultivate a cheerful spirit while watching the hopeful way she will go after it. 


\section{I.XXII.-September Notes}

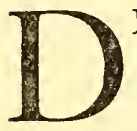

ID you ever stop (slap!) to consider the the mosquito? Did it ever occur to you that if a boy had an appetite in proportion to his size like that of a mosquito (slap!) he would eat a whole ox at a meal? Perhaps you think a mosquito too small a thing to occupy your thoughts. If so (slap!) you have another guess coming. Until science made a few epochmaking discoveries the mosquito prevented some of the mightiest works. Because it carries the germs of yellow fever it delayed the building of the Panama canal for years and increased the cost of all kinds of public works. By carrying the germs of malaria and giving people the ague it made the clearing of many parts of Canada doubly hard. (Slap! slap!) And this year it is a temper-rousing, sleepdestroying pest. With every cow-track full of water it has breeding places everywhere and you can hear its hum wherever you go. (Slap! Missed again!) Even though we have screens on the windows and 


\section{SEPTEMBER NOTES}

doors we cannot keep them out of the house because they come in riding on people's backs while waiting for a chance to bite. And did you ever consider how naturally mean the mosquito is? Not content with driving its beak into a fellow it injects a poison and possibly some disease germs. Of all created things the mosquito is about the most useless and irritating. Its snarling hum-(Slap! Whoop! Got him that time and now I can talk about something else.)

$$
\text { * * * * }
$$

About the first sign of fall is to have the cattle get into new fields. During the earlier months they are confined to the pasture but as the crops are taken off they are allowed a wider range. As soon as they find a new field open to them they rush into it as eagerly as if they were getting into mischief and do not rest until they have wandered to every corner. Even though the new field may offer them many bits of good pasture they do not stop to eat them but go around the fences and poke their heads through wires to get what they can from the adjoining field. The pasture they have never seems to satisfy them. It is the pasture in the other field that interests them. In this they are very human. 


\section{THE RED COW}

But giving them a wider range makes the chore of bringing them home at milking time more important and this summer I undertook to train Sheppy to the work with a rather peculiar result. As he is a pure-bred sheep dog he always goes to the farthest off in the bunch as soon as he is sent after them. This is usually enough to start the herd towards the barn and as soon as he has started them I call him off so that he walks quietly behind them. When the cattle became used to being brought home by Sheppy they apparently learned something. The dog is usually wandering away somewhere with the children and when I need him I have to whistle for him. During the past couple of weeks as soon as I began to whistle for Sheppy the cows started for the barn. Now I can get them home whether the $\mathrm{dog}$ is around or not simply by whistling. All of which goes to show that old Fenceviewer I. and her progeny are not like other cows. 


\section{LXXIII._"The Demon Rabbit"}

I

AM almost convinced that there is, or was, a demon rabbit in this neighbourhood. You all know the stories that come from far countries about ghostly tigers and phantom lions that seem to bear charmed lives, and to be invulnerable to the bullets of the most skilled marksman. According to the talented liars who tell the stories they are the actual bodies of dead and gone lions and tigers that "revisit the glimpses of the moon" to torment hunters. The rabbit $I$ have been having experiences with seems to be of this kind. He appears in the open with insulting indifference, and so far we have no evidence that he has been seriously injured by our attempts to get him. But before proceeding with my story perhaps I had better say a few words to put myself on the right side of the law. I have a hazy recollection that the game laws protect rabbits, but I make my appeal to an older code which asserts that "self-protection is the first law of Nature." I do not mean this in the sense 


\section{'THE RED COW}

in which it was used by the sheep thief, who, when caught red-handed, protested indignantly, "I'll kill every doggoned sheep that tries to bite me." I am not afraid that the rabbits will bite me, but, besides the young orchard, between two and three thousand seedling forest trees have been planted in. the wood-lot and I do not want to have them all girdled. Game laws or no game laws, we have been obliged to begin a war of extermination against the rabbits on the place. Perhaps that is why we are being tormented by this unshootable rabbit.

$$
\text { * * * * }
$$

For some weeks past a particularly large rabbit has been reported almost every day as crossing the road into the hedge and heading towards the orchard. At different times when I was driving to the postoffice he squatted by the fence and stared at me. He seemed so tame that I thought we would have no trouble with him until the boys had missed him a few times. Then I took the rifle and went after him myself. Of course I do not claim to be an unerring marksman, but still my record for picking off such small game as English sparrows is fairly good and in trying for rabbits during the fall $I$ did not make many misses and I never had such a chance as I 


\section{"THE DEMON RABBIT"}

have had at the demon. The first morning I went after him I spied him sitting up on his hind legs at the corner of a stack. It was as pretty a shot as a pot hunter could ask for, and as we were treating rabbits as vermin rather than as game, I felt no scruples about the lack of sportsmanship in shooting at him when standing still. As a matter of fact I am not sure but it is entirely sportsmanlike to shoot at a standing rabbit with the rifle. I never managed to stop but one with a bullet when it was on the run and the attempts $I$ have made since have convinced me that that shot was an accident. Anyway, Mr. Rabbit was sitting up offering a provokingly good target when I drew a bead on him and fired. Zip! He whirled and disappeared around the stack in two jumps. As I approached the place where he had been standing I saw something floating in the air and grabbed it. It proved to be a bunch of rabbit fur and on the ground where he had been there was a lot more. Next day I found him squatted beside the trunk of an apple tree, took deliberate aim and fired. Just one jump and a little white tail flirted saucily under a rail fence and disappeared. On the ground where he had been standing I found enough rabbit fur to stuff a pin-cushion, evidently I had 


\section{THE RED COW}

made another of those near-hits. Next day we were driving past the place where $I$ had shot at him and one of the boys was carrying the rifle. Suddenly, I spied Mr. Rabbit among some tall grass under the roadside fence. Grabbing the gun I took careful aim and fired once more. He seemed to be badly frightened, but that was all, and this time there was enough fur where he had been sitting to stuff two pin-cushions. I couldn't have been more than a rod from him this time and it hardly seems possible that if he were a normal rabbit that I shouldn't have hit him fair and square. However, he hasn't been seen since and it is just possible that he decided that things were getting a little too hot for him. If he appears again I think I shall have to try him with a silver bullet for that is said to be the only thing that will kill a demon of this kind. But perhaps, instead of using the silver to shoot with I should offer a quarter to a boy who is a better shot than I am to get him for me. Anyway, I have no need to fear the game wardens about this rabbit for I did no more to him than the Western desperado did to the Tenderfoot. I just shot him through the thin places around the edges. And yet-and yetit is just possible that it was not my bullets that 
knocked out the fur after all. This may be the season of the year when rabbits are changing their hair and he might have been merely attending to his toilet when I disturbed him by shooting at him. But demon or no demon, we must get him before he gets the little trees. 


\section{LXXIV.-The Fate of "The Demon Rabbit"}

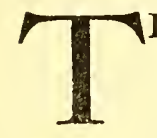

HE demon rabbit is no more, and the manner of his passing is as mysterious as anything else in his enchanted life. As nearly I can determine he died of heart disease or from rupturing an artery through sudden fright. This is how it happened. A couple of days after my last futile shot at him I was driving to the village. After turning out of the lane I came to the spot haunted by the rabbit, and there he was "as big as life and twice as natural." He was sitting under a branch that had been blown from an apple tree about a rod from the road. The three younger children were with me, and as soon as they saw him they began to yell, but he never wiggled an ear. Pulling up the horse I looked at him carefully, and seeing that he showed no signs of moving I yelled at the top of my voice for a boy to come with the rifle. Still the rabbit did not stir. I had to yell four or five times before the boy heard me, and though I made a noise that roused the echoes over 


\section{THE FATE OF "THE DEMON RABBIT"}

half the township the rabbit sat where he was. It took the boy fully five minutes to come with the rifle, and in the meantime the children and I were all talking at once while the demon sat and listened. Only when the boy was within a few rods of the buggy did he show any signs of nervousness. $\mathrm{He}$ slapped his hind feet on the snow a couple of times and I thought he was going to run, but he quieted down again. Then I drove on, for the horse is inclined to be gun-shy, and the boy dropped on one knee in the most approved Theodore Roosevelt fashion and took aim. When he fired the rabbit gave a jump that sent the snow flying and loped away across the orchard. The boy complained bitterly because I had not held the horse and allowed him to take a rest on the hind wheel of the buggy, and, while I watched the rabbit disappearing, I made a few restrained remarks appropriate to the occasion. But just as he was passing out of sight he suddenly jumped into the air, fell to the ground, kicked wildly and then lay still. I sent the boy running to where he was, and he picked up $\mathrm{Mr}$. Rabbit stone dead. Then we proceeded to examine him. The first thing we noticed was a round bullet hole through his right ear that was partly healed. 


\section{THE RED COW}

Across his back there was a furrow through his fur, and a long scab where a bullet had raked him. Under his chin there was a similar furrow and scab. Beyond a doubt he was the rabbit from which I had been knocking the fur. But what mystified us completely was the fact that we could not find a mark to show where the last bullet had hit him. Not a sign of blood or a wound could we find. After I got back from the village I held a post mortem on that rabbit, and though he was full of blood, having bled internally, the closest examination could not discover a trace of a wound. He must have ruptured a blood-ressel in his wild jumping. In no other way can I account for his sudden taking off. Of course the boy was anxious to prove that he had hit the rabbit, but he was unable to find a bullet mark any more than I was. And now there is something else to prove that he was not an ordinary rabbit. When I passed his haunts yesterday I saw two more rabbits. Isn't that the popular belief about evil things? If you kill one two more will come to take his place. Now I am going after the two new rabbits to see if four will come to take their place. I tried the rifle on some English sparrows at the granary and find that my shooting eye is just as 


\section{THE FATE OF "THE DEMON RABBIT"}

good as ever. Surely if I can hit such little targets as sparrows I should not miss rabbits if they are of mortal breed. Altogether it is a great mystery, and, in a more superstitious age, the incident would hare given rise to a myth, but in this sceptical age I suppose most people will explain the matter by insinuating that we are a family of poor shots. Yet the boy and I can both pick off sparrows just as easy as easy. 


\section{LXXV.-My Friends, the Trees}

$\mathrm{N}$

EAR the house there is a sturdy oak tree that I always think of as one of the oldest of my friends. I grew up with it. Of course, that is not exactly true, for I stopped growing many years ago while it kept on growing, and it may keep on growing for centuries to come. But when I was a growing boy it was just the right kind of a tree for me to chum with. It was not too big to climb, and yet it was big enough to take me on its back and carry me into all the dreamlands of childhood. Among its whispering branches I found lands as wonderful as Jack climbed to on his beanstalk. And it had a stout right arm that was strong enough to hold up a swing on which I swung and dreamed for more hours than the teachers of to-day would consider right. When it whispered to me I whispered to it, and told it more secrets than I have ever told any one in the world. It became a part of my life, and no matter how far I wandered in later years my thoughts would always 


\section{MY FRIENDS, THE TREES}

return to the tree in times of sickness and trouble. I always felt that I would be well and happy again if I could only get back to the tree and throw myself at full length on the grass that it shaded and listen to its never-ending gossip with the breezes that are forever visiting it. At last $I$ came back from the outer world and made my home beside the tree. During my absence it had pushed up higher and had spread its branches wider, but it was still the same companionable tree. The grass still made a carpet over its roots, inviting me to sprawl at full length and renew our voiceless communion. While I was away I may have learned some things, but the tree had been in harmony with the universe from the moment it began to emerge from the acorn, and knew all that I so sorely needed to learn.

$$
\text { * * * * }
$$

Although the oak is my particular friend among the trees on the farm, there are others with which I can claim at least an acquaintanceship. There is a maple at the edge of the wood-lot that always makes me feel uncomfortable, because I have a feeling that it has a joke on me. It stands on what would be called rising ground-which means an elevation that does not deserve to be called a hill-and while lying 


\section{THE RED COW}

on the grass in its shade I can see over several farms to the south and east. It used to be a favourite of my boyhood, and once I composed a poem while lying in its shade. If you bear in mind the fact that I was seventeen years of age at the time you will understand why the tree has a joke on me. Here is the only stanza I can remember of the little poem I composed to express the "unmannerly sadness" of youth.

It long has been my cherished hope

Upon my dying day

To lie down on some sunny slope

And dream my life away.

At that age I could not have cherished the hope so very long, and the old tree must have chuckled to its last twig at my absurdity. Anyway, I never see the tree without recalling that wretched stanza, and I immediately hurry away to some other part of the woods.

$$
\text { * } \quad * \quad * \quad *
$$

But there is one tree on the place with which I can never establish a feeling of intimacy. It is the one remaining specimen of the original forest-a giant maple over three feet in diameter, whose spread- 


\section{MY FRIENDS, THE TREES}

ing top rises far above the other trees in the woodlot. Even though it stands beside the public road, it seems to retain some touch of the shyness of the wilderness, and does not invite the fellowship of man. Its first branches are so high in the air that it has never been profaned by the most venturesome climbers, and its great roots start out from the trunk in a way that seems to thrust back all attempts at familiarity. The second growth maples by which it is surrounded appear to be domesticated by comparison with this wildling, and when they are tapped at sugar-making time they yield sap as lavishly as a dairy cow gives milk. But the giant gives grudgingly, as if it resented the wound it had received. Its companionship seems to be with the wildest winds and storms, that alone have the power to rouse its huge branches to motion.

$$
* * * *
$$

I sometimes wonder that I should be fond of trees, for when I was a boy trees were regarded almost as enemies. The land had to be cleared of them before crops could be sown, and they multiplied the labour of the pioneers. I learned to swing an axe by cutting down saplings, and ran "amuck" among them just as my elders did among the larger trees. In those 


\section{THE RED COW}

far days trees were things to be destroyed, and no one thought of sparing them. But when I came back to the farm and found that the noble forest had dwindled to a small wood-lot that had no young trees in it-because the cattle had nibbled down all seedlings for many years-I was seized by a rage for planting. Finding that the government was willing to supply seedlings to any one who would plant them out, I immediately began the work of reforestration and planted thousands so that when the present trees mature and are cut out there will be others to take their place. These little trees are now thriving lustily, but they seem to regard me with an air of aloofness, and I feel when among them as if they were looking at me furtively and trying to decide whether I am to be trusted. Perhaps there is still a tradition in the wood-lot of the havoc $I$ wrought in my youth with just such tender saplings as these.

$$
* * * *
$$

Yesterday while I was sitting at some distance from the home oak, admiring the curved spread of its branches, a bare-foot boy came out of the house. Without seeing me he walked straight to the tree and then looked up at its inviting branches. After 


\section{MY FRIENDS, THE TREES}

a while he got a piece of a rail and placed it against the trunk. Then with clutching fingers and spreading toes he worked his way up to the lowest branch. Through the higher branches he clambered as if going up a ladder, and finally when he found one to his liking he bestrode it, with his back to the trunk, and looked away to the south. For a long time, with childish gravity, he gave himself up to the "long, long thoughts" of a boy. At last his eyes began to rove around and presently they rested on me, where I was watching him. He laughed in a shame-faced way as if he had been surprised in doing something that he would have kept secret, but I laughed back joyously and we understood. I am glad that there is another of my name who will love the old oak and the other trees and to whom they will perhaps give their friendship even more fully than they have given it to me. 


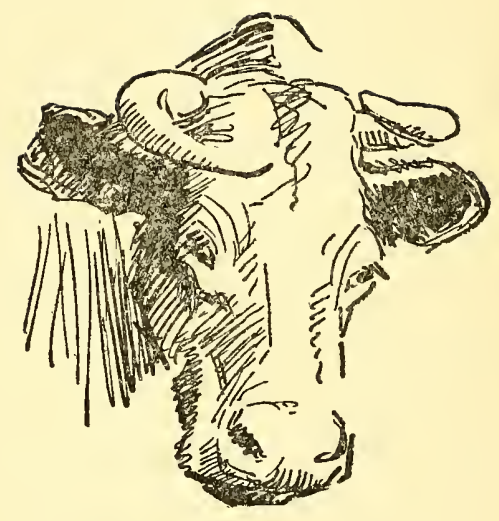




$$
\begin{aligned}
& \text { Decas s } \\
& \text { 2-wk पस 29 } 1975 \\
& \text { MAY } 71963 \\
& \text { Nons - . Pres } \\
& \text { 4.WK JUN 3 } 1968 \\
& \text { Rurenes } 1900
\end{aligned}
$$




\section{CIRCULATES \\ 630.1 \\ Mll8r}

Aaron Bldg.

612866 
